\title{
LEGENDARY OBSCURITY The working life of Malcolm Ross
}

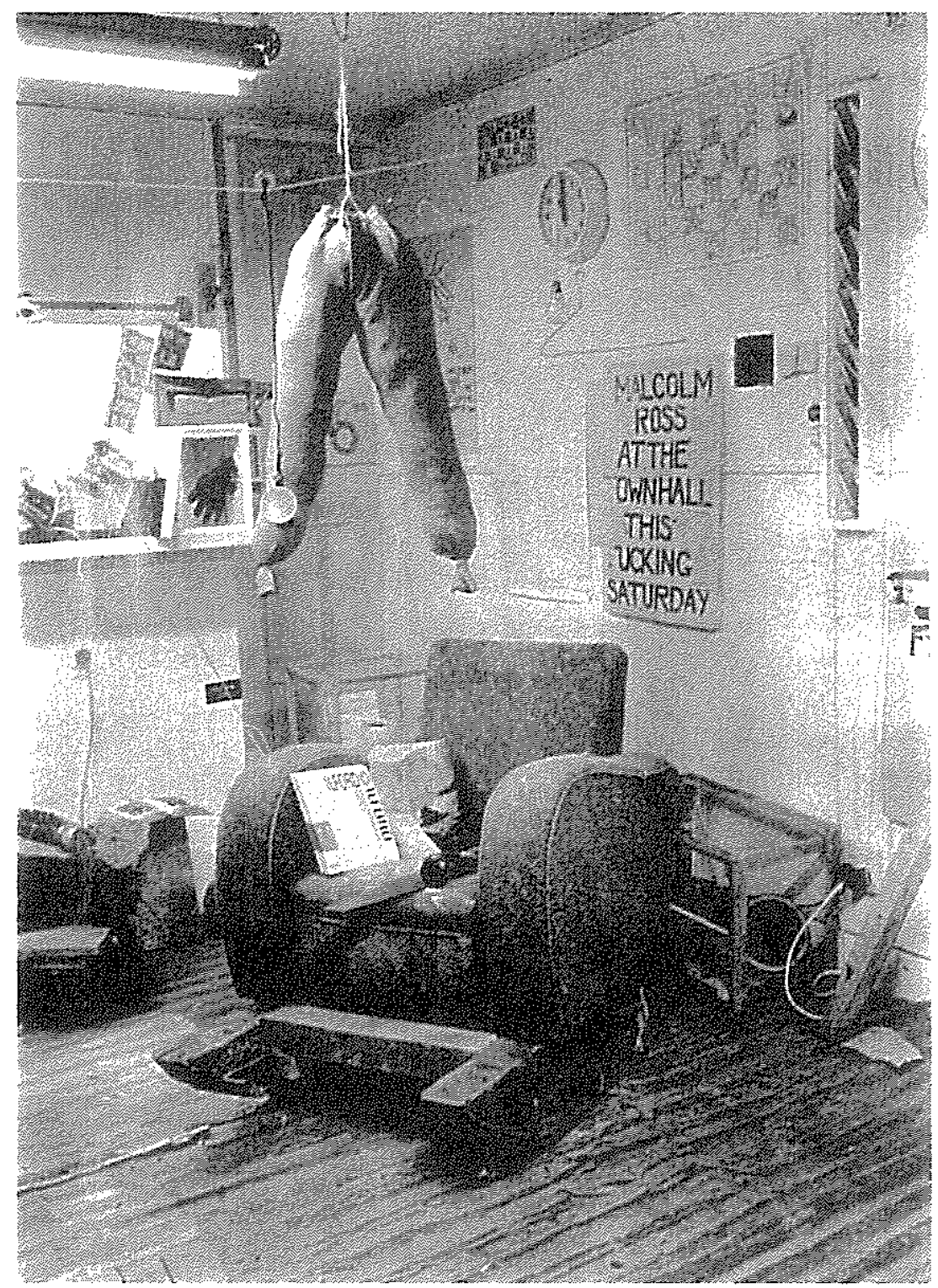

Matt Plummer

A thesis submitted to Victoria University of Wellington in fulfilment of the requirements for the degree of Master of Arts in Art History

Victoria University of Wellington 
ABSTRACT iii

ACKNOWLDEGEMENTS iv

LIST OF ILLUSTRATIONS v v

CHAPTER ONE $I$

'Legendry obscurity': Introducing Malcolm Ross

CHAPTER TWO

'My native suburb goodnight':

Malcolm Ross and New Zealand

CHAPTER THREE

'Duchamp foundation':

the conceptual underpinnings of Malcolm Ross's practice

CONCLUSION

'I ll still be here when you re gone':

Malcolm Ross's archival legacy

APPENDIX

'Long may your remains':

The Malcolm Ross Archive at the

E.H.McCormick Research Library

BIBLIOGRAPHY 
Malcolm Ross (1948-2003) was a sculptor, painter, photographer, cartoonist and historian who operated at one remove from the art world for the entirety of his career. As a consequence, almost no analysis, criticism or writing on his work exists, and his place within this country's history of art has subsequently been overlooked. This thesis seeks to give art historical and analytical attention to Ross's oeuvre, arguing for his status as one of New Zealand's key conceptual practitioners. It traces the thematic threads which recur throughout his work and argues that the diverse range of artistic and historic investigations he undertook are ultimately unified within his archive at the E.H. McCormick Research Library, Auckland Art Gallery Toi o Tamaki. 


\section{ACKNOWLEDGEMENTS}

Researching Malcolm Ross has been a challenging task, and I have been extremely fortunate to receive assistance from a number of people in this process. First of all I wish to acknowledge the incredible generosity shown to me by Douglas Wright, the executor of the Malcolm Ross Estate, whose support has made this project possible. I am grateful to Roger Peters (who first introduced me to the legendary obscurity of Malcolm Ross in 2003) and Paul Hartigan for their engaging discussions and friendship. Ron Brownson provided important insights into Ross's archival process at an early stage in my research, as did Mark Baldwin, who supplied key pieces of the 'puzzle' at pivotal moments. Additionally my knowledge of the working life of Malcolm Ross has been invaluably aided by his friends and peers who so generously gave up their time to talk to me: Jim Allen, Tony Green, Vicky Hamill, Bronwen Muir, Glenn White and Richard Wolfe have my sincere gratitude for this.

An archive-based project such as this has required much institutional support. In particular I would like to acknowledge the assistance of Catherine Hammond and Caroline McBride at the E. H. McCormick Research Library, Auckland Art Gallery Toi o Tamaki, and also Martin Collett at the Auckland War Memorial Research Library.

I have received much support from the Art History programme at Victoria University of Wellington over a number of years. I wish to thank my supervisor Tina Barton for her patience and editorial acumen, Roger Blackley for going above and beyond the call of duty, and Peter Brunt for his input in the early stages of my research. Additionally David Maskill, Pippa Wisheart and Annie Mercer have helped in a variety ways, all of which are much appreciated.

Finally, I wish to express thanks to Jo Whalley, whose editorial assistance and general encouragement were instrumental in enabling me to get over the finish line. 


\section{LIST OF ILLUSTRATIONS}

Fig. 1 Malcolm Ross, Untitled [Elam Studio Self-portrait], 1971

Black and white photograph

E.H. McCormick Research Library, Auckland Art Gallery Toi o Tamaki

Fig. 2 Diego Velazquez, Las Meninas [detail], 1656

Oil on canvas. Prado, Madrid

Page 6

Fig. 3 Richard Wolfe, Have you read Malcolm Ross's thesis yet?

Printed in Elam S(p)eed, no 2, 1972

Page 15

Fig. 4 Malcolm Ross, Grades, 1971

'Feasibility', from Untitled (or $A++$ )

Fig. 5 Malcolm Ross, Untitled [Bull/bullshit], undated

Ink on photocopied image.

E.H. McCormick Research Library, Auckland Art Gallery Toi o Tamaki

Page 26

Fig. 6 Malcolm Ross, De Chirico versus fish and chips, undated.

Stamped ink on paper

Douglas Wright collection

Fig. 7 Malcolm Ross, In the beginning was Jackson Pollock, undated. Ink on paper

E.H. McCormick Research Library, Auckland Art Gallery Toi o Tamaki

Page 36

Fig. 8 Malcolm Ross, In the beginning was Jackson Pollock /

Jackson Pollock alcoholic, undated

Stamped ink on paper

Douglas Wright collection

Page 37

Fig. 9 Malcolm Ross, Crucified Directory, 1971

'Fact', from Untitled (or $A++$ )

Page 46

Fig. 10 Malcolm Ross, Inside Out-house [interior], 1971

Fig. 11 Malcolm Ross, Inside Out-house [exterior], 1971

'Facts', from Untitled (or $A++$ )

Page 49 
Fig. 12 Jim Allen, New Zealand Environment No 5, 1969

Mixed media installation

Govett-Brewster Art Gallery collection

Page 50

Fig. 13 Malcolm Ross, New Plymouth topographical inch to mile sheet, 1971

'Fact', from Untitled (or $A++$ )

\section{Page 55}

Fig. 14 Malcolm Ross, Untitled [Hollywood McCahon], undated Ink on paper

E.H. McCormick Research Library, Auckland Art Gallery Toi o Tamaki

Fig. 15 Ronnie van Hout, Dead artists, 1992

Black and white photograph

Private collection, Wellington

Page 63

Fig. 16 Malcolm Ross, Near Miss, 1992

Oil on board

Douglas Wright collection

Fig. 17 Colin McCahon, Crucifixion with lamp (detail), 1947

Oil on canvas

Hocken Library, Dunedin

\section{Page 64}

Fig. 18 Malcolm Ross, Duchamp Foundation, c. 1980

Black and white photograph

E.H. McCormick Research Library, Auckland Art Gallery

Toi o Tamaki

Page 73

Fig. 19 Malcolm Ross, Untitled [High-heeled pipe], undated Ink on paper

E.H. McCormick Research Library, Auckland Art Gallery Toi o Tamaki

Page 75

Fig. 20 Malcolm Ross, Pegged-out books, 1971

'Fact', from Untitled (or $A++$ )

Fig. 21 Marcel Duchamp, The Bride Stripped Bare by Her

Bachelors, Even [detail]

1915-23

Oil, varnish, lead foil and lead wire on two glass panels

Philadelphia Museum of Art

Page 79 
Fig. 22 Malcolm Ross, Selected self-portraits, c1971-1980

Black and white photographs

from Untitled (or $A++$ ) and The Malcolm Ross Archive

E.H. McCormick Research Library, Auckland Art Gallery Toi o

Tamaki

Page 83 


\section{'LEGENDRY OBSCURITY'}

\section{Introducing Malcolm Ross}

People tend to focus on the figureheads of the time, but it's not necessarily the figureheads who are going to tell the story.

- Jim Allen ${ }^{1}$

I think that he is absolutely unique, and that his work, as it comes to light, will be understood as prophetic. It will change our perception of late twentieth-century art in New Zealand. It will add another dimension to it.

$$
\text { - Douglas Wright on Malcolm Ross }{ }^{2}
$$

To the people who knew him well, Malcolm Ross is legendary. Within this circle of friends he is commonly acknowledged as one of New Zealand's most talented and prescient artists, yet outside it his work remains largely unknown. ${ }^{3}$ Whilst there is little novel about an artist who fails to gain a public reputation, Ross's case is more interesting - rather than struggling for recognition, he struggled with and against it. After achieving notoriety as a talented yet unconventional student at Auckland's Elam School of Fine Arts in the late 1960s and early 1970s, Ross was encouraged to exhibit his work by a number of well-regarded peers. Yet despite compulsively creating art right up to his death (in 2003), his end-of-year exhibition at Elam in 1971 proved to be his last; operating at one-remove from the art world for the remainder of his life, Ross bypassed the conventional avenues for artistic reception. Instead he chose to deposit a range of material in several archival repositories throughout New Zealand. While a large portion of this material stems from Ross's idiosyncratic research on local history, his most significant deposit (totalling 18 storage cartons, housed at the E.H. McCormick Research Library

\footnotetext{
${ }^{1} \mathrm{Jim}$ Allen, interview with the author, 8 February 2006.

2 Douglas Wright, interview with the author, 6 November 2006.

${ }^{3}$ Both Ross and his art do feature prominently in Douglas Wright's memoir Ghost Dance, Penguin: Auckland, 2004, and to a lesser extent its sequel Terra Icognita, Penguin: Auckland, 2006, and thus he will be familiar to those who have read these books. Ross was also the subject of my article 'I'll still be here when you're gone: the archival strategy of Malcolm Ross', Reading Room 1, 2007, pp 175-180, and is briefly mentioned in Peter Wells' 'A singular bliss', The Bulletin, Winter June-August 2009, pp 28-29.
} 
at the Auckland Art Gallery) includes a sizable selection of notes, sketches, paintings and photographs from his artistic oeuvre. ${ }^{4}$

Utilising this archival material in combination with an analysis of works in private collections and the recollections of those who knew him, this thesis is an attempt to unearth and illuminate aspects of Malcolm Ross's working life. In it I will examine the extent to which Ross might be considered a key practitioner of conceptual art in a local context, whilst highlighting how his work provides a foil to existing accounts of contemporary art practice in New Zealand. What will emerge is a story focussed not on a recognised figurehead, but rather on a unique character at the margins, and in the footnotes, of this history.

Due to the nature of his work and personality, the task of introducing Malcolm Ross as an art-historical subject is not easy. His archival material is at once voluminous and fragmentary; his extant work presents intriguing insights into his working methods, yet frustratingly there are relatively few examples of these ideas being cohesively assimilated into "finished" works. Due to Ross's frequent refusal to follow art-historical conventions such as signing and dating pieces it is difficult to place much of his work within a chronological narrative, and the recurrent absence of titles often makes discussion of it problematic and cumbersome. Nevertheless it is a central contention of this thesis that these elliptic, partial remnants - the survivors of an intense and unrelenting destructive drive - can amount to an oeuvre worthy of analysis, particularly when viewed in light of art-historical trends emerging over the past four decades.

Indeed, I believe the very things which make Malcolm Ross a problematic subject also grant him a rather unique relevance in this climate of "new" art history, in which artists who challenge conventional approaches can be seen to

\footnotetext{
${ }^{4}$ See the appendix 'Long may youtr remains ' for a more detailed itemisation of Ross's archived material at the E.H. McCormick Research Library. 
effectively widen the discipline's field of vision. Throughout my account I will examine Ross's unique approach to pursuing a career in art; clarifying how his work self-consciously employs, challenges and subverts the conventions of traditional art history, and thus how it mirrors developments occurring within the discipline itself. ${ }^{5}$ By outlining key biographical events I hope to provide a platform from which some insights into this often inscrutable character may be gleaned.

In focussing on the life and work of a single artist, this project ostensibly follows the most traditional of art-historical templates, the monograph. Any such account - in which an artist's biography is placed alongside analysis and discussion of their work - must negotiate the divide between these two, at times divergent, strands. An acknowledgement of this tension has informed recent discussions of both art writing and the discipline of art history, notably in accounts such as Hal Foster's 'Autonomies in Art History', Donald Preziosi's 'The Art of Art History', and Mieke Bal's writing on Louise Bourgeois. ${ }^{6}$ Indeed, Bal utilises the neologism "autotopography" to suggest a new approach to writing about artists and their work which circumvents some of the perceived pitfalls associated with a more traditional approach. ${ }^{7}$ While I do not claim to be able to avoid entirely these pitfalls in this account, my discussion of Ross is informed by these approaches.

One of Bal's main criticisms of art writing based on an a biographical approach is that such accounts too often "prop [themselves] up against the artist's statements and stories" resulting in "biographical narratives that sidestep or even ignore what is most characteristic of the artist's work: its visual nature." Whilst my approach to Ross - which will focus on a

5 In which the so-called "crisis" has led some people to propose a new, interdisciplinary approach to visual subjects under the rubric of visual culture. For an overview see 'Questionnaire on Visual Culture', October, no 77 (Summer 1996), pp 25-70.

${ }^{6}$ Hal Foster, 'Autonomies in Art History' in Design and, Crime (and other Diatribes), Verso: London and New York, 2002, pp 83-103. Donald Preziosi, 'The Art of Art History', in Preziosi (ed), The Ant of Ant History: A Critical Anthology, Oxford University Press: Oxford and New York, 1998, pp 507-527.

${ }^{7}$ Mieke Bal, 'Autotopography: Louise Bourgeois as builder', Biography 25.1, Winter 2002, pp 180-202. 
cumulative impression created by his archival 'remains', and which will extend beyond his visual art to include a consideration of his historical writing - in some ways presents a challenge to Bal's autotopographical approach, I do wish to adopt a key aspect of her strategy by beginning my account with a close reading of one Ross's works.

To this end I have selected a photographic self-portrait of Ross to function as a visual epigraph for my discussion. Dating from his honours year at Elam in 1971, Untitled [Elam Studio Self-portrait] [Fig.1] captures an impression of Ross at a moment when his artistic potential was at its zenith, and in the space (his Elam studio) where he created some of the most remarkable and intriguing works of his career. On initial inspection this appears to be a straightforward depiction which does no more than provide a simple record of Ross in his studio environment, surrounded by a selection of his work and the equipment used to document it.

Part of the casual impression created by this work radiates from the central figure of Ross himself: leaning on his 'wall seat' made from $4 \times 2$ buttresses and an old bicycle seat, dressed in denim jacket, jeans, and jandals and with a characteristically dead-pan expression on his face, he projects a nonchalant indifference that belies the carefully constructed nature of this image. Holding in his left hand the camera's shutter cord, Ross is clearly identified as the photographer, but the only way this image can 'work' is if the camera is pointed at a mirror - it thus turns out that what is depicted is not Ross himself, but rather his mirror image; an inversion of the artist; a reflected impression. ${ }^{8}$ In a sense this photograph operates as a metaphor for Ross's idiosyncratic approach to his artistic career, which - in being addressed primarily to posterity rather than the public - inverts the established conventions for art reception.

\footnotetext{
${ }^{8}$ In using the mirror to stage a self-portrait Ross might be seen to reference Marcel Duchamp, who utilised reflections more overtly in his portrait Photograph of Marcel Duchamp Taken with Hinge Mirror (1917).
} 
As in much of Ross's art, closer scrutiny of this image renders the seemingly straightforward and superficial surprisingly complicated and multi-layered. Ross's ostensibly relaxed posture is, I believe, no accident, but rather a meticulously staged performance. Careful inspection reveals that as in a number of other works from this period, Ross's pose directly quotes from an existing art work - here not only is the viewer presented with a mirror image of Ross, but also of Velazquez's pose in the latter's famous 'meta-painting' Las Meninas (1656, Prado, Madrid) [Fig. 2]. It is interesting to note that in both these works the artist directly returns the viewer's gaze whilst engaged in the act of representation.

Supplanting the paint brush and easel of Velazquez with a camera and its shutter-cord, Ross's image marks a transition from painting to sculpture and photography. During Ross's initial enrolment at Elam in the mid-1960s he had studied painting under Colin McCahon, but at the time this photo was taken he was creating a wide range of objects in a variety of media in the sculpture department, many of which exist now only in the photographic documentation provided by the very camera depicted in this image. If Las Meninas can be viewed as a painting about painting, [Elam Studio Self-portrait] brings to the forefront the process of photographic documentation, a process integral to Ross's archival approach. ${ }^{9}$ It is a photograph which, in many ways, is about photography. ${ }^{10}$

\footnotetext{
${ }^{9}$ For insights into the representational complexity of Las Meninas see Michel Foucault, 'Las Meninas', The order of things: An archaeology of the human sciences, Vintage: New York, 1970, pp3-16, and Svetlana Alpers, 'Interpretation without representation, or, the viewing of Las Meninas,' [1983] in Eric Fernie (ed), Art history and its methods. Phaidon: London, 1995, pp 285-290.

${ }^{10}$ That painting has been supplanted by sculpture and photography in Ross's practice is further indicated in this image by the splashes of paint visible on the camera tripod, which suggest that it was once used as an easel. The work which populates the wall behind Ross also presents examples pertinent to this discussion. At the image's top left edge is a photograph of the performance work "The glad-wrap kid" (in which Ross cohort Paul Hartigan was wrapped in glad wrap and photographed sequentially as he broke free), and the work directly above Ross's head consists of Peter McIntyre's 1953 painting The Royal Yacht Gothic Entering Auckland Harbour which has been - rather iconoclastically wrapped in translucent grease-proof paper.
} 


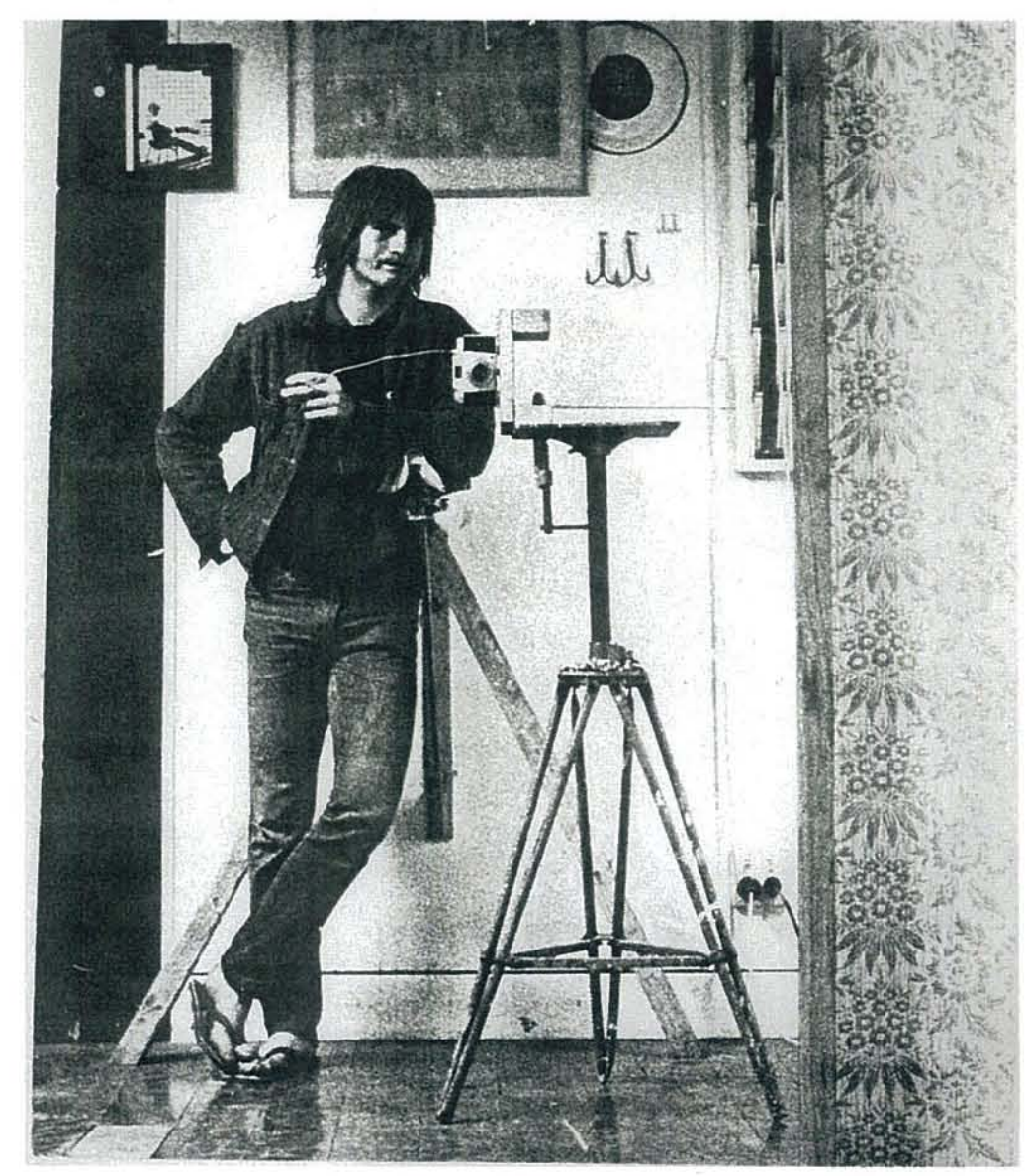

Fig. 1. Malcolm Ross, Untitled [Elam Studio Self-portrait], 1971 Black and white photograph

E.H. McCormick Research Library, Auckland Art Gallery Toi o Tamaki

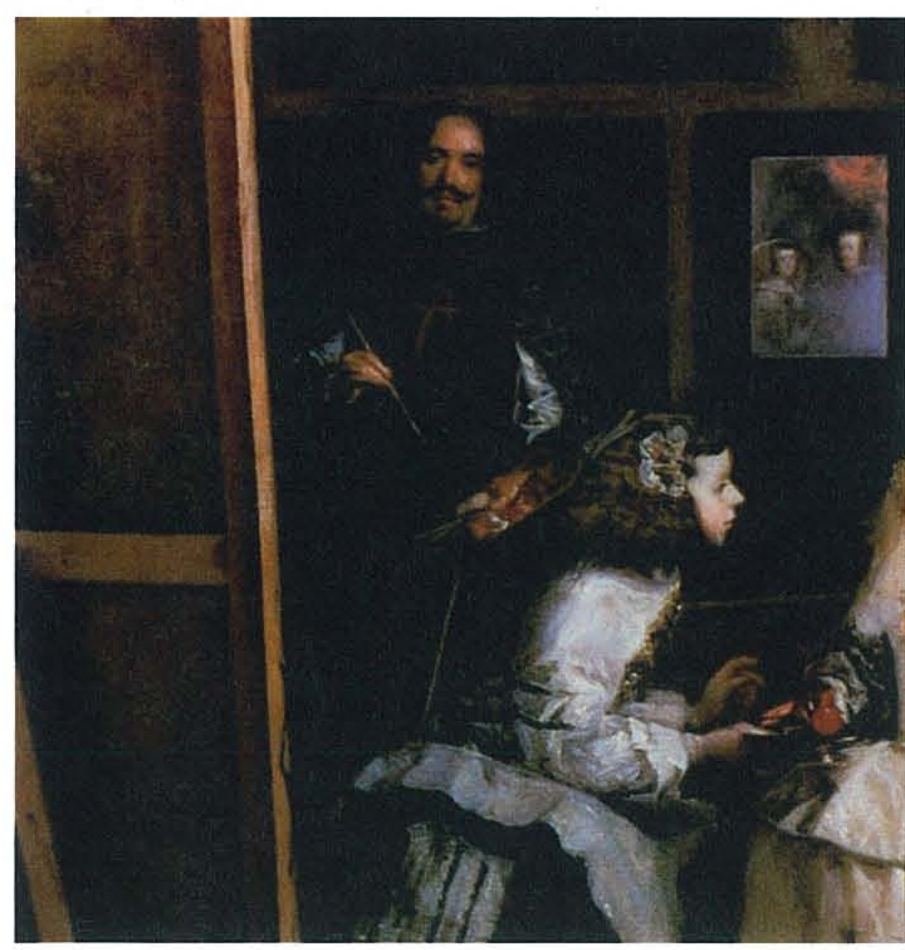

Fig. 2. Diego Velazquez, Las Meninas [detail], 1656 Oil on canvas. Prado, Madrid 
According to Donald Preziosi, "art history is in a very real sense the child of photography .. . it was photography which made it possible ... to think art historically in a sustained and systematic fashion." "Clearly foregrounding the process of photography in this work, I believe [Elam Studio Self-portrait] can in fact be interpreted as an image which is addressed directly to art history via the archive. Whilst depicting Ross in his honours year, this work does not appear in his thesis Untitled (or $A++$ ) in which much of this year's work is documented. Thus the archive appears to provide the only avenue for its reception. In selecting and placing an image which has never been exhibited - which has never had a public 'life' - in his archival collection, I suggest that Ross consciously presents this work to [art] history, utilising the archive as a kind of conceptual frame in which his youthful impression is preserved for posterity. ${ }^{12}$

[Elam Studio Self-portrait] is thus a photograph pregnant with meaning, one which, typical of Ross's work, marries dead-pan humour with conceptual depth. Like Las Meninas it can be viewed as a meta-image which comments on the very nature of representation. It highlights a degree of self-reflexivity seen in many of Ross's works, and provides an intriguing glimpse into his idiosyncratic artistic sensibility. It is this sensibility which I will attempt to examine and illuminate over the course of this thesis, and in order to do this, I propose an approach that will not attempt to provide a comprehensive catalogue raisonné of Ross's oeuvre, but will instead focus on a select range of images which I believe to be most revealing about Ross's artistic personality.

Ross himself may not have approved of such an approach. According to Mark Baldwin, Ross had issues with the way the curatorial process often seemed to

\footnotetext{
11 Donald Preziosi, 'The Art of Art History', p 522.

${ }^{12}$ I do not want to give the impression that [Studio Self portrait] is unique in Ross's archive. As almost all of his archival material was not exhibited or reproduced else where, much of this material functions in this way. I will explore further the extent to which the archive functions as a framing device in the final chapter of this thesis.
} 
reflect the concerns of the curator rather than the artist. ${ }^{13}$ Baldwin highlights that Ross found the selection process problematic, a notion which is clearly present in the introduction to Untitled (or $A++$ ), where Ross writes "This is a haphazard survey of my year's work . . . it isn't complete but it is completely uncritical and unselective." 14 But by depositing his work in an archive, in a sense abandoning it to the whims of history, Ross has surrendered the control over his work which he guarded so closely during his lifetime. ${ }^{15}$

However, while my approach is selective, and inescapably resembles the curatorial selection process Ross found so problematic, I will endeavour as much as possible to account for his artistic oeuvre as a single body of work, as befits the nature of a life-long project 'uninterrupted' by the exhibition process. The works I focus on will, I hope, provide a sufficient reflection of the diverse range of styles and media utilised in Ross's work, and will function in an emblematic fashion.

My approach is based on what I perceive to be the fundamentally conceptual nature of Ross's practice, although given his diverse output and tendency to explore a range of different avenues in his art, many other approaches could be taken. ${ }^{16}$ The final words of Ross's historical account of The New Zealand Society of Sculptors and Painters seem pertinent here. He writes, "It is hoped that [this report] will provide other users with a framework to dispute." ${ }^{17}$ I hope my own account will operate in a similar fashion.

\footnotetext{
${ }^{13}$ Mark Baldwin, interview with the author, 14 February 2006.

${ }^{14}$ Malcolm Ross, 'Introduction' in Untitled (or $A++$ ), unpublished Diploma of Fine Arts Thesis, Auckland: University of Auckland, 1971, unpaginated .

${ }^{15}$ Although it should be noted here that Ross entrusted the guardianship of this work to Douglas Wright, his posthumous kaitiaki, the executor of his estate.

${ }^{16}$ In particular, there is fertile (though potentially problematic) ground for an approach which focuses more on Ross's homosexuality and sexually-oriented figurative work, as implied by Peter Wells in his essay 'A Singular Bliss'.

${ }^{17}$ Malcolm Ross, The N.Z.S.S.P.A Records - a report, unpublished, $\mathrm{p} 47$. Held in the Malcolm Ross Archive, E.H. McCormick Research Library, Auckland Art Gallery Toi o Tamaki.
} 


\section{A biographical sketch of the artist}

Malcolm Ross's vocation was being Malcolm Ross . . he didn't want any public recognition - he didn't need it - and by not needing or wanting it he had more freedom.

- Ron Brownson ${ }^{18}$

As suggested already, in focussing on the life and work of a single artist, this project ostensibly follows the most traditional of art-historical templates, yet due to the nature of the subject my thesis will in many ways differ from a conventional monograph. Nevertheless for clarity's sake it seems imperative to satisfy the basic requirements of the monograph with a biographical sketch of the artist's life. ${ }^{19}$

Malcolm McDonald Ross was born in Takapuna, Auckland on 13 April 1948, the second child of Ruth Miriam Ross (nee Guscott), a historian, and Ian Munson Ross, a journalist and returned soldier who later trained as a school teacher. ${ }^{20}$ For Ross, fascination with history was in the blood; not only was his mother a pioneering researcher on Te Tiriti o Waitangi, but his great uncle (and namesake) was a well known author, mountaineer, photographer and New Zealand's first war correspondent.

In 1955 the Ross family moved north to the Hokianga when Ian took up a teaching position at Motukiore Maori School. As the name suggests, it was an almost exclusively Maori community, with the Rosses being one of the few Pakeha families in the area. ${ }^{2 \mathrm{I}}$ This immersion in Maori culture would leave a lasting impression on Ross, and both his art and historical research reflect his sustained interest in (and deep respect for) Maoritanga. He also developed a

\footnotetext{
${ }^{18}$ Ron Brownson, interview with the author, 6 November 2006

${ }^{19}$ This biographical account is by no means comprehensive, but is complemented by that provided in Douglas Wright's Ghost Dance, pp 28-41, 122-139, 187-192, 211-223.

${ }^{20}$ Boyd, Mary, 'Ross, Ruth Miriam 1920 - 1982'. Dictionary of New Zealand Biography, updated 22 June 2007

URL: http://www.dnzb.govt.nz/default.asp?Find Quick.asp?PersonEssay $=2 T 56$, accessed 2/8/2007.

${ }^{21}$ Wright, Ghost Dance, p 31.
} 
fascination with ornithology at this time - amongst the earliest works to be found in his archive at the Auckland Art Gallery Research Library are handdrawn maps marking the locations of various bird nests in the Motukiore area. $^{22}$ Although Ross struggled with written language, and was castigated by his parents for being slow to progress in reading and writing, these early images betray a nascent yet sophisticated visual vocabulary.

For Ross, investigating the world of birds was an introspective and solitary endeavour - his discoveries were guarded with the utmost secrecy; minute, spidery writing was developed to record information in the most covert of manners. It was an early example of the seclusion and secrecy which would become recurring themes in his life, taken to such extremes that it seems reasonable to account for his art practice as a predominantly hermetic endeavour. $^{23}$

In 1960 the Ross family moved to Rangitane on the Pouto peninsula, Kaipara, with Ian taking up a teaching post at Rangitane Maori School. Here Ross continued to develop his fascination with Maori culture, local history, geography and the secret world of birds. Between 1961 and 1965 Ross attended Northland College in Kaikohe as a boarding student. It is from this period that the earliest existing correspondence from Ruth to Malcolm dates. ${ }^{24}$ Giving intriguing insights into the relationship between mother and son, these letters highlight Malcolm's continuing difficulties with grammar and spelling - a rather humorous telegram from Ruth simply reads "WACH WRITING = MUM+". ${ }^{25}$ However, Ross continued to draw prolifically during this period, and with the encouragement of art teacher Selwyn Wilson he enrolled at the Elam School of Fine Arts in Auckland on completion of his high school education.

\footnotetext{
${ }^{22}$ For an interesting discussion of the origins of this work see Ghost Dance, pp 31-35.

${ }^{23}$ For example, Mark Baldwin's recalls how, despite being his partner and cohabiting with him, Ross always maintained his own space and guarded his work closely.

24 This correspondence is now housed at the Auckland War Memorial Museum Archives as part of the substantial and voluminous Ruth Ross papers. MS 94/23; Folders 1-5.

${ }^{25}$ Ruth Ross to Malcolm Ross, MS 94/23(2), 28 June 1962.
} 
Ross's studies focussed on painting and drawing during this initial enrolment at Elam between 1966 and 1969. It was at this time that he met painting teacher and well known artist Colin McCahon, and the two struck up a friendship based on a mutual love of art and alcohol. McCahon would go on to describe Ross as one of his most talented students. ${ }^{26}$ Correspondence from McCahon to Ross (also held at the E. H. McCormick Research Library) gives some indication of the nature of their friendship, with McCahon adopting a warm, paternalistic tone, encouraging Ross to "ring, come round, drop in anytime," 27 and thanking him for an earlier letter even though "I knew the ordeal of a reply to you was going to be the inevitable result.,"28

At the end of 1969 Ross moved to New Plymouth, where he was employed in the part-time position of Gallery Technician at the as yet unopened GovettBrewster Art Gallery. Working under newly appointed gallery director John Maynard, Ross's first job involved assisting in the installation of fellow Elam alumnus Leon Narbey's Real Time (1970, Govett-Brewster Art Gallery, New Plymouth). This opening show, which saw all three floors of the gallery transformed into an interactive audio-visual installation, was a bold gambit by Maynard and Narbey, and became a watershed moment in contemporary art practice in this country. ${ }^{29}$ Correspondence with his mother reveals Ross's invigoration at being involved at the "ground floor" of such a novel enterprise. $^{30}$

\footnotetext{
${ }^{26}$ Ron Brownson, interview with the author, 6 November 2006; Bronwen Muir, conversation with the author, 23 January 2008.

${ }^{27}$ Colin McCahon to Malcolm Ross, 8 March 1972, Colin McCahon Archive, Auckland Art Gallery Toi o Tamaki

${ }^{28}$ Colin McCahon to Malcolm Ross, 27 March 1972, Colin McCahon Archive, Auckland Art Gallery Toi o Tamaki. For further discussion of this correspondence and the relationship between Ross and McCahon see the section "And all the people shall stone him" in my second chapter.

${ }^{29}$ See Anthony Green, 'Culture's most remote province?', New Zealand Listener, Sep 21, 1970, p 22. For an account of Real Time's on-going impact see Christina Barton, 'Pushing the envelope: developments at the Govett-Brewster Art Gallery,' Ant New Zealand 87, Winter 1998, pp 56-59.

${ }^{30}$ Ruth Ross to Malcolm Ross, MS 94/23(2), 24 November 1969.
} 
Despite his position at the gallery being made full-time, in 1971 Ross returned to Elam to complete his honours diploma in Fine Arts, this time enrolling in the sculpture department. Heading the department was Jim Allen, who had recently returned from a sabbatical to Britain and the United States, where he had witnessed first hand the revolutionary fervour enveloping those countries' art schools. Allen adopted a number of new teaching philosophies back at Elam, the result being a collaborative and highly creative environment in which traditional barriers between teachers and students were consciously eroded. $^{31}$

Even though this was a time of great camaraderie, Ross maintained a certain aloofness, although his presence certainly registered amongst his peers. According to Allen, "he was a recluse, but he was also always there (on campus) ... he had his own thing going." 32 Fellow student Richard Wolfe recalls, ". . . a lot of students at Elam shared studio space and became colleagues and friends, but Malcolm was more aloof . . I can't imagine [he] would have conformed to any group philosophy, on principle." ${ }^{33}$ However there were notable exceptions to this rule, with Ross incorporating his close friends Bronwen Muir and Paul Hartigan in a number of works during his honour's year.

Ross's thesis, provocatively titled Untitled (or $A++$ ), is in many ways a document exemplary of the type of work being produced at the time, revealing a debt to both French artist Marcel Duchamp and contemporary conceptual practice, but also showing his own antipodean take on this material. At the end of the year Ross was awarded the Fowld's Memorial Prize for achieving the highest marks in the fine arts department, thus imbuing his title with

\footnotetext{
${ }^{31}$ An overview of the Elam environment in the late 1960s and early 1970 s, which gives substantial insight into both creative and educational processes at the institution, can be found in Michael Dunn's article 'Paul Beadle' in Nicholas Tarling (ed.) Auckland Minds and Matters, University of Auckland Press: Auckland, 2003, pp 20-31.

$32 \mathrm{Jim}$ Allen, interview with the author, 8 February 2006.

${ }^{33}$ Richard Wolfe, interview with the author, 14 June 2006.
} 
another layer of irony. ${ }^{34}$ This award was no small accolade considering the calibre of work that was being produced during this period - work still considered over thirty years later to be some of the most ground-breaking and innovative sculpture in our recent art history. ${ }^{35}$

Ross's honours year amounted to a high point in his burgeoning art career, and in many ways he never rekindled the energy that enabled him to create so prolifically and consistently. Despite his reclusive ways, he was something of a star at Elam. ${ }^{36}$ But rather than acting on the suggestions of a number of people to exhibit more widely the work he had created for his thesis, Ross opted to destroy much of the work and move to Wellington to enrol at the National Library School in early 1972. During this time it appears that Ross suffered a nervous breakdown. After dropping out of the school early on in the trimester he was sent to psychiatrist at his parents' insistence. ${ }^{37}$

Correspondence with his mother highlights her concerns about his alcohol consumption, something that - along with his art production and cigarette smoking - would become a recurring motif of his life. ${ }^{38}$ Indeed Ross's habits bring to mind Kurt Vonnegut's famous quip about committing suicide by cigarette. Ross added alcohol to the mix as well, and Ruth had reason to be worried about her son's drinking habits. In a letter to Malcolm dated March 16, she writes:

I came back from Wellington with one over-riding fear, that you [Malcolm] would use alcohol as a crutch to help you through Library School. And I knew that if you did, the only result would be major disaster . . for goodness sake, lay off the grog. ${ }^{39}$

\footnotetext{
${ }^{34}$ Ruth Ross to Malcolm Ross, MS 94/23(5), 10 March 1972

${ }^{35}$ For a general overview of the period, see Christina Barton, Post-object ant in New Zealand 1969-1979, unpublished MA thesis, Auckland: University of Auckland, 1987, and Action Replay: postobject art, Artspace and Govett Brewster Art Gallery: Auckland and New Plymouth, 1998.

${ }^{36}$ In Ghost Dance Douglas Wright describes Ross as the enfant terrible of his honours year at Elam, p 187

${ }^{37}$ Ruth Ross to Duncan Ross, MS 94/23(1), 31 May 1972. According to Bronwen Muir, Ross went on to complete his qualification, although this seems to contradict information conveyed in this correspondence.

${ }^{38}$ Ruth Ross to Malcolm Ross, MS 94/23(5), 16 March 1972.

${ }^{39}$ Ruth Ross to Malcolm Ross, MS 94/23(5), 16 March 1972.
} 
As indicated by the title of this section, this suggestion was not one which Ross took up for any length of time.

During this period a revolution of sorts broke out at Elam, in which fine arts students rebelled against the requirement that they take Art History papers on Poussin, as taught by Tony Green (who had recently arrived from the United Kingdom). In the wake of May '68 and the politically charged student scene of the late $1960 \mathrm{~s}$, fine arts students objected with revolutionary fervour to what they considered to be an exercise in irrelevance. Indeed, the second edition of Elam $S(p)$ eed, a student-initiated publication, was devoted entirely to this debate, with strongly worded articles by David Schofield, Colin McLaren and Richard Wolfe articulating the belief that there was little to be gained from Green's teachings on Poussin that was at all useful or relevant to their practice as would-be artists operating in the late twentieth-century. ${ }^{40}$ In response, Green and Michael Dunn argued that the Department was underresourced; that the subject of art-historical investigation was not as important as the process involved; and that the past had in fact many lessons for the present. It was a time in which the fine arts and art history were uneasy bedfellows at best.

Despite the fact that Ross had left Elam by this stage, he still came up in the debate, his name evoked in Elam $S(p)$ eed by the slogan "Have you read Malcolm Ross' thesis yet?"[Fig. 3] which accompanies Richard Wolfe's colourfully titled article 'On the Art History Front, A Case Against Mental Abuse. ${ }^{41}$ According to Wolfe, Ross's thesis typified the kind of work which had a currency and relevance entirely absent in Poussin - and conveniently perhaps, the thesis was not only a work of the moment, but one which took direct swipes at the art-historical discipline, including as it did numerous

\footnotetext{
${ }^{40}$ These students also objected to a new degree and a programme in Art History

${ }^{4}$ Richard Wolfe, 'On the Art History Front, A Case Against Mental Abuse', Elam S(p)eed, no 2, 1972.
} 


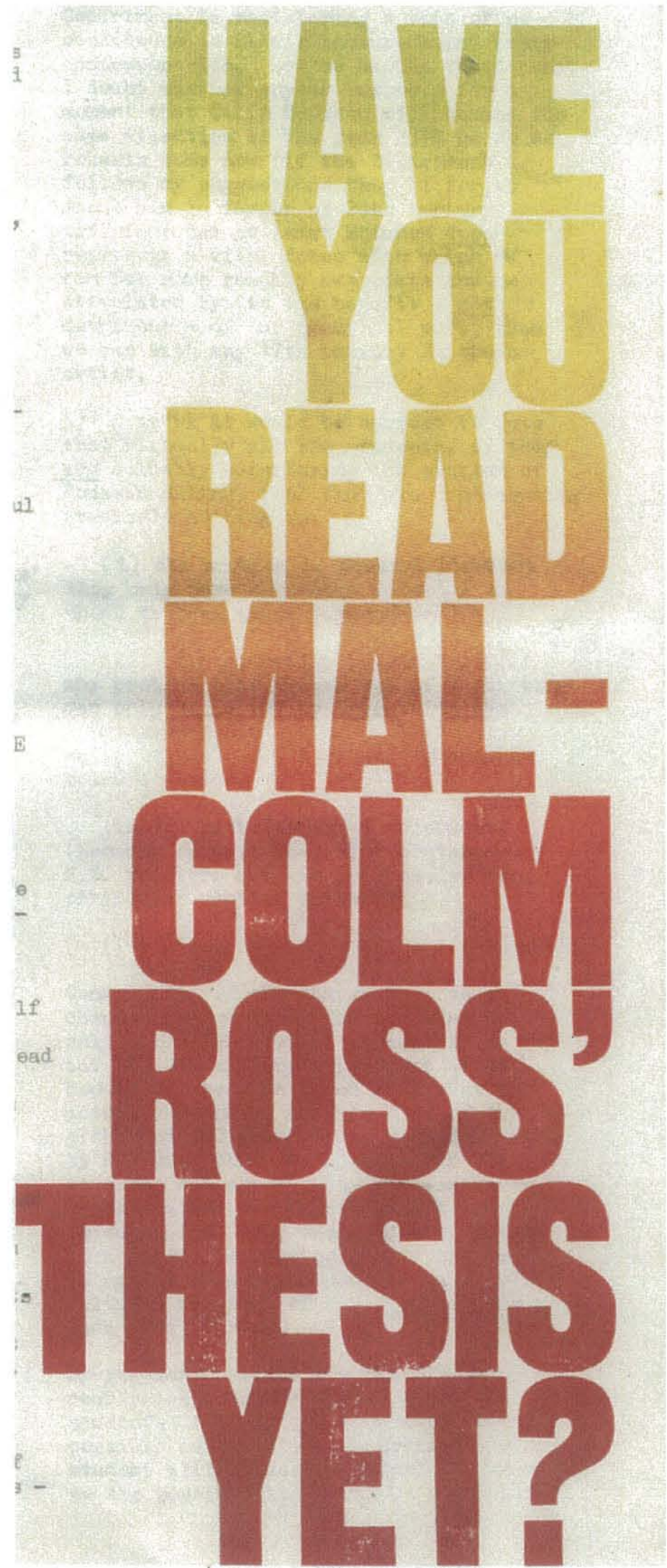

Fig. 3, Richard Wolfe, Have you read Malcolm Ross 's thesis yet? Printed in Elam S(p)eed, no 2, 1972 
history of art texts which were written-over, manipulated and mutilated in various ways so as to render them unreadable. ${ }^{42}$ Indeed, much of the work in Ross's thesis highlights his love/hate relationship with art history, a theme which will be further developed later in this account.

Following his failed stint at library school in Wellington, Ross returned to Auckland and set about finding work in various fields related to his interests in art and history, largely to no avail. Living at home with his parents for periods, Ross worked part-time as a community art teacher and dish-washer but struggled to find a vocation. ${ }^{43}$ All the while he continued to create. In the mid-1970s Ross completed a number of illustrations and cartoons for the University of Auckland's student magazine Craccum which remain interesting today as markers of the political climate of the period, and also reflect Ross's counter-cultural position and left-leaning attitudes.

A key factor in Ross's marginalised position was his homosexuality. Ross's Craccum illustrations were published at a time when homosexuality was still illegal in this country, and a number of works reflect his strong opinions on censorship and belief that New Zealand was a police state (particularly under the leadership of Prime Minister Robert Muldoon). ${ }^{44}$ Over the course of his life Ross's two most significant relationships were with Mark Baldwin and Douglas Wright, who were effectively his muses and the models for much of his figurative work. Although issues of gender underpin several works in Untitled (or $A++$ ), specific references to homosexuality are largely absent; however, sexuality, transgression and taboo would become increasingly significant facets of Ross's work in later years.

The death of his mother in 1982 seemed to have a considerable impact on Ross, both on a personal level and also in relation to his archival impulses.

\footnotetext{
${ }^{42}$ For a further discussion of works from Ross's thesis, see 'Duchamp Foundation.'

43 Ruth Ross to Duncan Ross, MS 94/23(1), 19 March 1976.

${ }^{44}$ It is also interesting to note here that, according to Ghost Dance, Ross was the third person in New Zealand to be arrested for possession of LSD. Wright, Ghost Dance, p 188. 
Following her death Ross spent a large amount of time ordering and cataloguing her extensive body of personal papers, correspondence and research, which were eventually deposited at the Auckland War Memorial Museum Library. ${ }^{45}$ Correspondence and interviews suggest that Ross felt that his mother had not received due credit for her pioneering research and his attention to the organisation of her papers reveals an interesting attitude to posterity, particularly in light of his subsequent archiving. It is perhaps no coincidence that Ross made the first of many archival deposits of his own around this time, placing material relating to New Zealand art (consisting of his personal correspondence with Theo Schoon and Colin McCahon) at Dunedin's Hocken Library in 1982 . $^{46}$

It was also around the time of his mother's death that Ross was commissioned to write a history of the New Zealand Society of Sculptors and Painters. The type of report which followed was typical of the research methods used by his mother to shed new light on Te Tiriti o Waitangi, entailing a thorough and critical examination of primary records to construct a historical narrative of the society's activities (although in this case it was one imbued with the author's idiosyncratic sense of humour and word-play, somewhat at odds with the scholarly tone one might expect of such a history). Interestingly, this account might be considered an early (if partial) historical overview of what has been viewed as a "lost chapter" in this country's art history - the postobject practice of the $1970 \mathrm{~s}^{47}$

As mentioned previously, throughout his life Ross consciously maintained a distance from the art world, although over the years a number of opportunities

\footnotetext{
${ }^{45}$ Ron Brownson, interview with the author, 6/11/2006. For more information on Ruth Ross, see Rachael Bell, Ruth Ross: New Zealand Scholar; Treaty Scholar, Unpublished MA Thesis, Palmerston North: Massey University, 2005.

${ }^{46}$ Hocken Collection, Misc-MS-1078/Misc-MS-1366.

${ }^{47}$ Malcolm Ross, The N.Z.S.S.P.A Records - a report, unpublished, held in that Malcolm Ross Archive, E.H. McCormick Research Library, Auckland Art Gallery Toi o Tamaki. Ross's report includes an account of the International Sculpture Symposium and discusses the role the society played in this scene, particularly with regard to the involvement of key figures such as Jim Allen.
} 
to exhibit his work arose. ${ }^{48}$ At one point in the late $1980 \mathrm{~s}$ - at the suggestion of Paul Hartigan and other friends and with the support of gallery owner Rodney Kirk-Smith - an exhibition of work was planned at Kirk-Smith's RKS Gallery in Auckland. Hartigan recalls:

Rodney knew Malcolm's work and was really, really keen for an exhibition. Rodney had approached Malcolm, Malcolm had sort of agreed, and I'd pushed it a little bit, and it was happening. But ... he got in there and he was like a cat in a cage, he backed out through the smallest hole. That was it ... [I thought] there was no chance of [him] exhibiting again, no chance of turning it around. $^{49}$

Despite this ambivalent attitude to the exhibition of his art, by the early $1990 \mathrm{~s}$ the idea that Ross would deposit work at the Auckland City Art Gallery was established. ${ }^{50}$ In many ways a self-archivist, Ross had kept voluminous notes, sketches and works pertaining to both his art and research of local history, and at the suggestion of his friend Ronald Brownson, then Librarian at the gallery's research library, it was decided that this would be an appropriate place to house much of Ross's material. ${ }^{51}$ According to Brownson, Ross deposited a selection of material (which ultimately totalled 18 boxes):

over a number of years as he processed it. It came to the gallery and was just put in escrow.. . That was what Malcolm wanted, he just wanted it to be kept here, not accessed by anyone - including myself or any other staff member - not indexed, not classified, just kept in the original format in which he had structured it. ${ }^{52}$

The accommodation in an art gallery archive of such a wealth of material from an artist who did not have a public reputation may well be unprecedented, and further discussion of how Ross's archive came into being is warranted here. It seems salient to point out that institutional archives such as the one maintained by the E.H. McCormick Research Library generally have limited space, and do not customarily accept all material submitted to them - particularly from artists who have never exhibited work to the public at large.

\footnotetext{
48 Douglas Wright, interview with the author, 6 November 2006.

${ }^{49}$ Paul Hartigan, interview with the author, 7 November 2006.

${ }^{50}$ Ron Brownson, interview with the author, 6 November 2006.

${ }^{51}$ Ron Brownson, interview with the author, 6 November 2006.

${ }^{52}$ Ron Brownson, interview with the author, 6 November 2006.
} 
That Brownson thought it appropriate to proactively encourage this archival deposit suggests much about the high regard he had for both Ross and his work, and also indicates that during this period he may have had the autonomy to facilitate this process with little interference from others in the institution. It is also important to point out that Brownson was well aware of the personal friendship between E. H. McCormick and Ross, and this link provides a further explanation why he felt it appropriate to oversee the creation of the Malcolm Ross Archive in this particular space. ${ }^{53}$ Commenting on Ross's attitude to libraries, Brownson highlights the link when he remarks that:

He regarded libraries as sacrosanct, and that regard of libraries as a cultural resource was something that he learned from his mother, but also admired deeply in his friend E.H. McCormick who was another person who considered libraries at the zenith of ways in which you can research culture through documentation. ${ }^{54}$

Here Brownson highlights Ross's acknowledgment of the importance of the archive as the foundation of historical research based on an examination of primary resources and first-hand records. A dedicated historical researcher of this type of material for the entirety of his life, Ross's engagement with the notion of the archive was neither fleeting nor cursory.

Ross continued to live in Auckland, painting, sculpting, drinking, smoking and working on various research projects until c.2000, when he moved north to Whangarei. He is variously described in archival records as an artist, arthistorian, photographer, sculptor, historian and dance-historian, but ultimately, as Ron Brownson said, Malcolm Ross's vocation was being Malcolm Ross. He was a researcher, an artist, an alcoholic. He died of cancer, aged 55, in 2003, leaving his archival deposits to Douglas Wright to either linger in obscurity or await historical resuscitation.

\footnotetext{
${ }^{53}$ During my first visit to the E.H. McCormick research library, Brownson made a special reference to the connection between McCormick and Ross. He told me that while McCormick was not one to suffer fools lightly, he was very fond of Ross.

${ }^{54}$ Ron Brownson, interview with the author, 6 November 2006. 
"As a rule of thumb, my method is to think of a shape, then embarrass the hell out of it. As visual puns [the works] are real groaners."

$$
\text { - Malcolm Ross, Introduction to Untitled }(\text { or } A++)^{55}
$$

Malcolm Ross's art work is nothing if not diverse, ranging from hand-crafted conceptual sculptures to abstract compositions to figurative works painstakingly painted in enamel with matchsticks. As his thesis witnesses, many of his pieces were simply ideas that required no physical form to validate their place in his body of work. Throughout his life Ross worked through different interests and obsessions, often concerning himself with a particular style or concept for a period of time before moving on to another phase; according to Ron Brownson: "Often it seemed to me in a two-to-three year period he would work on a thematic ... there [are] pockets of that sort of thing throughout all of his vocation." ${ }^{.56}$ Although largely unordered and undated, even a cursory inspection of Ross's archived work reflects this point.

Yet despite creating art in a range of media and working through a number of thematic concerns, there is a logic and consistency which underlies this diverse array of work. Ultimately what unifies Ross's work is that it is clearly the product of a single mind - his art is the by-product of an obsessive and unrelenting drive to create; his extant pieces are the survivors of an equally strong compulsion to destroy. Viewed individually, much of Ross's surviving work might be dismissed as sketchy, unfinished and insignificant, yet taken as part of a wider, conceptual project, all these components (which frequently cross-reference and mutually reinforce each other) help form an oeuvre. The sketches, scribbles and photocopies of Ross's archive along with his more finished works in private collections are like the individual tiles of a mosaic - when viewed collectively and from a distance they reveal a clearer picture. I have identified four key facets, ulterior motifs if you will, which commonly

\footnotetext{
${ }^{55}$ Malcolm Ross, 'Introduction' in Untitled (or $A++$ ), unpublished Diploma of Fine Arts Thesis, Auckland: University of Auckland, 1971.

${ }^{56}$ Ronald Brownson, interview with the author, 6 November 2006
} 
recur throughout his ongoing yet ultimately unfinished life-long project. These facets - ideas, humour, craft and quotation - help provide the glue for the "mosaic", linking together Ross's various thematic and stylistic interests.

\section{IDEAS}

"He loved doing the opposite; while everyone was abstract, he went figurative. His style was infectious, it was the conceptual stuff that singled him out."

- Mark Baldwin on Malcolm Ross ${ }^{57}$

Underpinning all of Ross's work is the notion that art is about ideas, and in this sense his art is fundamentally conceptual. ${ }^{58}$ In employing concepts relating to the functioning of art history, representation and language in selfreflexive and playful ways, Ross distinguished himself from artists concerned with representation or form in and of itself.

It was a perceived emphasis on formal concerns at the beginning of the twentieth-century that led Marcel Duchamp to call for painting to return to the service of the mind, and interestingly the burst of conceptual activity in the late 1960 s and early 1970 s also followed a period of art history dominated by formalism. ${ }^{59}$ That Duchamp is now considered an important predecessor to conceptual practice in the latter half of the twentieth-century is no coincidence, and his call to return art to the service of the mind is one which Ross consistently took up, regardless of the medium he happened to be working in. In many ways, Duchamp can be considered a key influence on Ross's development as an artist. Douglas Wright recalls that although "Malcolm never really talked about Duchamp ... the visual evidence [showed] that Duchamp was his master."

\footnotetext{
${ }^{57}$ Mark Baldwin, email to the author, 11 August 2006.

58 This is a point borne out by a number of interviewees, but one made most succinctly by Mark Baldwin. It is important to note that whilst much of Ross's work closely resembles commonly accepted ideas of conceptual art, his figurative and abstract work is equally built on a foundation of the concept.

59 I refer here to prominence of Clement Greenberg and abstract expressionism's commercial success.

${ }^{60}$ Douglas Wright, interview with the author, 6 November 2006.
} 
Much of my chapter Duchamp Foundation will be devoted to exploring Duchamp's influence on Ross, particularly in relation to the prominence of concept and content; it will discuss comparisons and key points of difference in their respective practices. Although this account will take into consideration a range of Ross's works, particular attention will be paid to those illustrated in his thesis.

But the term "illustrated" is problematic here. Two-thirds of Ross's work in Untitled (or $A++j$ - namely that contained in the sections Feasibilities and Fictions - were never carried out; existing only as ideas, they took the notion of the 'dematerialisation' of the art object (a cornerstone of early conceptualism) to its logical conclusion. The type of work present in Ross's archive also confirms his prioritisation of the idea over the finished product. Whilst he frequently destroyed carefully crafted works, his archival material reveals that what he was careful to preserve was often not a finished product, but rather the sketch or note which captured an original idea. In this sense he can be aligned not only with Duchamp (who made voluminous, often cryptic notes about his work), but also with conceptual practitioners of the 1960 s and 1970 s who were trying to escape the over-commercialisation of the art object. Sol Le Wit, a key player in American conceptualism, concisely conveys this mindset in 'Paragraphs on Conceptual Art', in which he writes:

If the artist carries through his idea and makes it into visible form, then all steps in the process are important. The idea itself, even if not made visual, is as much a work of art as any finished product. All intervening steps scribbles, sketches, drawings, failed work, models, studies, thought, conversations - are of interest. Those that show the thought process of the artist are sometimes more interesting than the final product. ${ }^{61}$

While Ross's reluctance to discuss his influences and motivations means that it remains unclear exactly to what extent he embraced conceptualism, his archival selection process suggests a close affinity with these sentiments. Le Wit's description of the intervening steps of art production reads like an

\footnotetext{
${ }^{61}$ Sol Le Wit, 'Paragraphs on Conceptual Art', in Alexander Alberro and Blake Stimson (eds.), Conceptual Art: A Critical Anthology, MIT Press: Cambridge, Mass., 1999, p 15.
} 
inventory of his deposited material. Although, as Mark Baldwin points out, Ross often reacted to artistic trends by doing the opposite, he nevertheless seems to have embraced aspects of conceptual practice, even when working in more conventional media. A number of the 'radical' principles pertaining to the reconfiguration of the art object and the expansion of what could be considered art can be see to recur throughout Ross's entire life project. However it is also important to emphasise the selective nature of this adoption of conceptual strategies. Much like Duchamp, Ross was careful to maintain a distance from fads and fashions.

\section{HUMOUR}

"Humour runs as a vein through all his work. . . [but] it has a politic to it."

- Ronald Brownson on Malcolm Ross ${ }^{62}$

Closely aligned with the notion that Ross's work is built on a foundation of the idea is his constant employment of humour, which operates on a number of levels in his oeuvre. As heralded by the introduction to his thesis, Ross frequently made use of visual and verbal puns, and did so not only to amuse but also to unhinge singular meaning, subvert codes of representation, and create open-ended possibilities in his art work.

A key insight into the type of humour his work incorporates comes at the end of Untitled ( r $A++$ ), where Ross inserts an index from a totally unrelated book on ornithology. A classic example of Ross employing a deliberate "mistake", here the index's traditional function is subverted, creating a humorous disconnection in which any attempt to utilise it as a reference section will result in a wild goose chase. ${ }^{63}$ This 'non-index' has gained a degree of notoriety, and is just one of the things Ross's Elam cohorts

\footnotetext{
${ }^{62}$ Ronald Brownson, interview with the author, 6 November 2006.

${ }^{63}$ Ross's use of deliberate mistakes, of which the title of this chapter could be considered another example, brings to mind the renaissance concept of typography in which "unexpected or seemingly inappropriate details are clues, not errors of expression." Christopher C. Hughes, 'Embarras and Disconvenance in Poussin's Rebecca and Eliezer at the Well', in Art History 24.4, September 2001, p 500.
} 
remember over 30 years later as a typically subversive gesture which counterbalanced the conceptual vigour of much of his year's work. Commenting on his first impressions of Ross's thesis, Richard Wolfe recalls:

I was aware that Malcolm was doing some interesting things, but I couldn't really get a grip on it [the work documented in the thesis]. I just remember I flicked through it, and there was this index . . I I must have turned to that, and thought, what the hell is this out of the Fontana bird guide book? And then I suddenly realised and had an instant overview and grip on Malcolm's sense of humour and attitude. $^{64}$

It could be pointed out here in order to "get a grip" on Ross's sense of humour, Wolfe need to have looked no further than the title of the thesis, Untitled (or $A++$ ), which speaks to a closely related (and equally important) aspect of Ross's sense of humour - self-deprecation. A number of works found in both Ross's thesis and archive show him engaged in ironic acts of self-promotion in which any suggestion of egotism is undercut by absurdist, dead-pan humour and deliberate self-sabotage, and the title of Ross's thesis provides one such example. ${ }^{65}$ Although the (non) title Untitled (or $A++$ ) may at first seem to suggest brash self-promotion, a work included within the thesis, Grades [Fig. 4], lays out a marking criteria in which an $\mathrm{A}++$ actually equates to a $\mathrm{B} .{ }^{66}$ Richard Wolfe also suggests another possible reading of the work when he recalls that:

... one of the things that was going on at Elam at that time, I think Jim Allen didn't have a lot of respect for the marking system, and his students regularly got $\mathrm{A}++.{ }^{67}$

So here Ross might be seen to poke fun at the 'departmental nepotism' suggested by such a gesture. This work and others seem to reinforce another of Richard Wolfe's observations, that, “. . . [Ross's] personal style of humour was unique at Elam . . . Everyone took themselves seriously, and obviously Malcolm did too, but in a totally different, light-hearted, ironic way." 68

\footnotetext{
${ }^{64}$ Richard Wolfe, interview with the author, 14 June 2006.

${ }^{65}$ See also my discussion of Untilled [Self-portrait with Halo] in 'I'll still be here when you're gone: The archival strategy of Malcolm Ross', pp 177-178.

${ }^{66} \mathrm{I}$ am grateful to Maree Horner for pointing this out to me.

${ }^{67}$ Richard Wolfe, interview with the author, 14 June 2006.

${ }^{68}$ Richard Wolfe, interview with the author, 14 June 2006.
} 
Indeed, in Ross's work the inter-relationship of humour and seriousness is both interesting and complicated. Despite inheriting from his mother a view that observing correct historical practices was sacrosanct, Ross did not shy away from poking fun at the machinations of history and the presentation of historical displays. Untitled [Bull/bull shit] [Fig. 5] consists of a photocopied image of a bull sculpture on a plinth, to which Ross has contributed a sketch of the bull's faecal matter, placed on a plinth of its own. What Ross seems to comment on here is the tendency for art and historical displays to place objects and artefacts on pedestals, in doing so artificially elevating their status and distancing them from the natural world they represent. Ross's treatment of bull shit simultaneously subverts this tradition whilst following its conventions - by valorising something traditionally considered waste material, Ross makes a mockery of this process and even goes so far as to assign the shit its appropriate figure index. Ross's humorous gesture highlights how preposterous it would for be the bull depicted to defecate in such a 'high-brow' context, and thus how distanced it is from the animal it represents. He seems to imply that the fact that the bull cannot shit is bull shit. This work provides another example of Ross employing the ubiquitous pun to reinforce his point, and brings to mind Duchamp's L.H.O.O.Q. (1919, p.c.) - if Duchamp demonstrated he was not afraid of killing sacred cows, Ross shows he knows bull shit when he sees it. ${ }^{69}$

In Untitled [Bull/bullshit], as in other works, Ross uses humour to both deflate pretentiousness and add an element of conceptual depth. If conceptual art has prompted some to wonder whether the proverbial emperor is wearing any clothes, Ross's use of humour provides a means of answering any accusations of self-importance proleptically. But as mentioned previously, Ross used humour to add varied strata of meaning to his work as well. According to Paul Hartigan, Ross's work “. . . always had many layers: there was the quick

\footnotetext{
${ }^{69}$ Indeed, many interviewees observed that Ross excelled at spotting falseness in others. According to Roger Peters, "no pretentiousness went unnoticed on his watch." Roger Peters, interview with the author, 6 September 2006.
} 


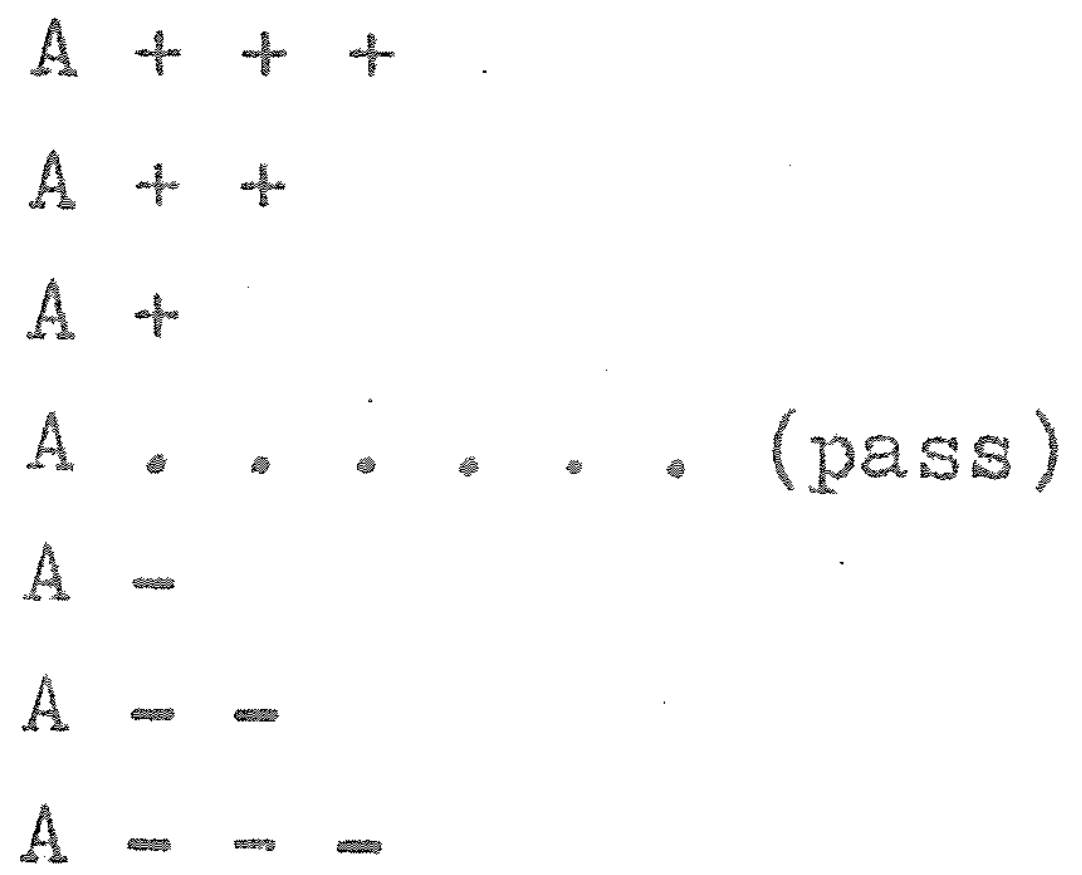

Fig. 4. Malcolm Ross, Grades, 1971.

'Feasibility', from Untitled (or $A++$ )

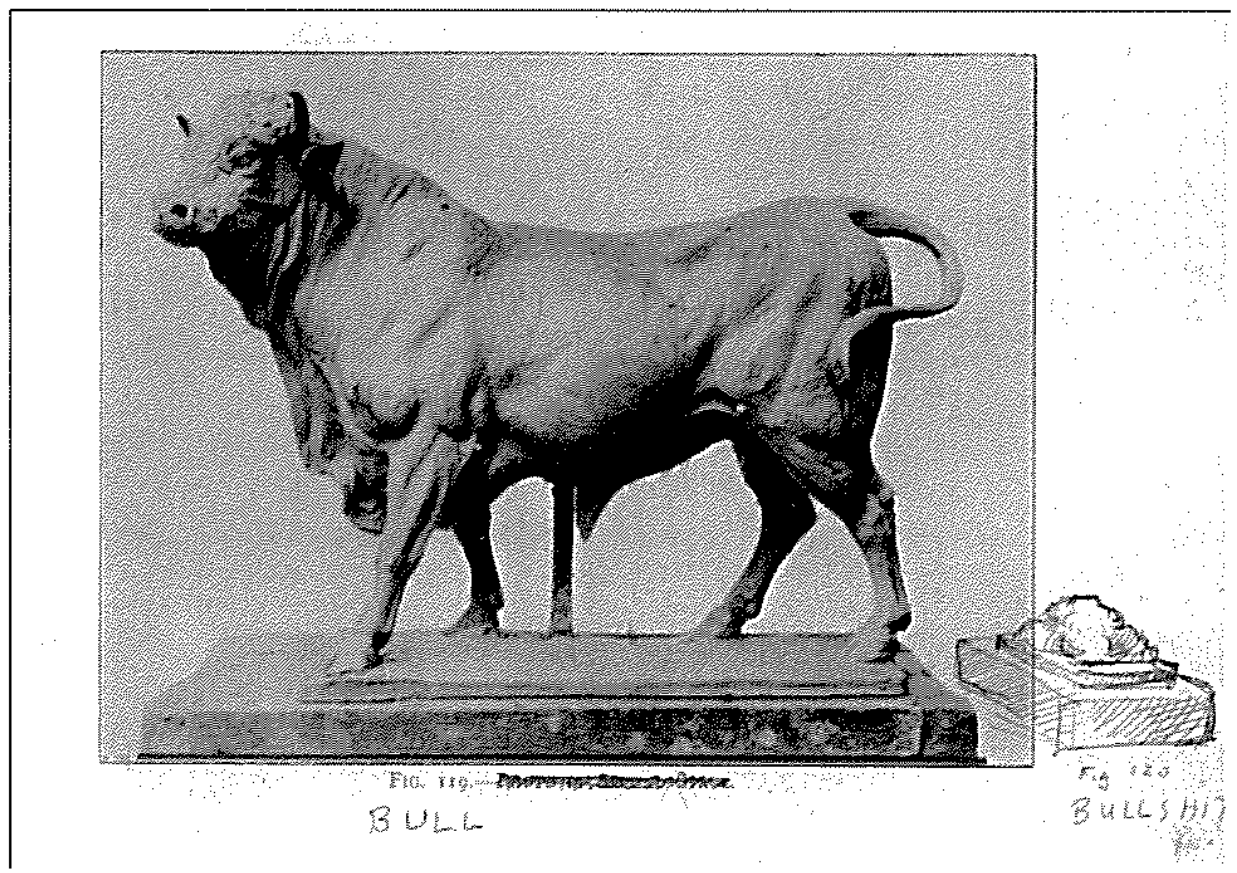

Fig 5. Malcolm Ross, Untitled [Bull/bullshit], undated. Ink on photocopied image.

E.H. McCormick Research Library, Auckland Art Gallery Toi o Tamaki 
joke layer, but there was also a much deeper context as well, a Duchampian context." ${ }^{, 70}$ Indeed, much of Ross's work brings to mind Duchamp's famous statement that "I wanted to introduce humour in my work. It wasn't a humour that just provokes laughter, neither was it black humour. It added something serious." 71 As in Duchamp's work, paradox flourishes in Ross's oeuvre, and humour occupies a central place in both their practices.

\section{CRAFT}

". . he was the most brilliant draughtsman . . Even though Malcolm made all this kind of cranky stuff, drawing was always a big part of the work."

$$
\text { - Paul Hartigan on Malcolm Ross }{ }^{72}
$$

For Ross it was important to have hands-on involvement in all stages of art production. In keeping with his autonomous approach, Ross manufactured his art himself, be it conceptual sculpture, figurative sculpture, drawing, or painting. Paul Hartigan's comments above highlight the importance of drawing in Ross's practice, and nine archived exercise books containing sketches underpinning his honours year's work also testify to this.

To convert these works from sketches to sculpture, Ross employed what might be described as a "number- 8 fencing wire" approach, utilising kiwi ingenuity and a fair amount of physical effort to create his finished products. This jerry-rigging was not limited to the works themselves, but extended to their documentation. A section of his thesis describing accessories utilised in the photographic documentation of his works gives some idea of his methods:

Accessories: a hypodermic-syringe-type shutter-release cord, necessary for slow exposures. A remote-control unit comprising a wooden upright nailed on a wooden box stabilised with bricks in the bottom. A gate in the top of the upright, through which the shutter-release cord is threaded. Lengths of string added as needed. (Max offered to get hold of a bellows-

\footnotetext{
${ }_{70}^{70}$ Paul Hartigan, interview with the author, 7 November 2006.

${ }^{71}$ Marcel Duchamp quoted in Jean de Drot (dir.), A game of chess with Marcel Duchamp, Phaidon, 1987.

${ }^{72}$ Paul Hartigan, interview with the author, 7 November 2006.
} 
arrangement; then he thought for a minute. "No, that's right, you're a sticks and strings man, aren't you?" Thanks Max. I liked that ... . ${ }^{73}$

Ross's appreciation of being described as a "sticks and string man" is revealing. Not only does it fit in with his approach of hand-crafting his works and jerry-rigging the devices needed to document them, it also suggests an embrace of amateurism which was in keeping with his self-deprecating philosophy.

But the manufacture of his thesis works is just one of many facets of Ross's approach to craft. According to Mark Baldwin, Ross claimed that in addition to art being about ideas, it was also about hard work. ${ }^{74}$ Ross laboured persistently at his craft, and over the course of his life mastered a variety of artistic techniques. ${ }^{75}$ Although he was able to mimic a number of styles, seemingly at will, he also developed highly idiosyncratic methods of his own. The most notable of these is his technique of creating intricately detailed figurative paintings using matchsticks and enamel. The discipline required to paint with matchsticks is telling, as is Ross's use of enamel, more traditionally used to paint houses than create "fine art".

Ross outlines his attitude towards painting in a letter to Mark Baldwin dating from November 1983, where he writes:

I've mucked about with enamels for years. Suddenly it came right. I can more or less do with them what I want. A large part of it is forgetting snobberies and blocks. The painting I most admire is late Victorian, its response to photography and its high colouring. I'm sick to death of modernism - I mean with a capital M. I see painting simply as a means of obtaining images. To set things up for photographs would in fact require a hell of a lot of organisation. To paint them is simpler. I used to waste so much time revising things from not properly planning them to begin with. I've dispensed with that largely. ${ }^{76}$

\footnotetext{
${ }^{73}$ Malcolm Ross, 'The Photographs' in Untilled (or $A++$ ), unpublished Diploma of Fine Arts Thesis, Auckland: University of Auckland, 1971.

${ }^{74}$ Mark Baldwin, interview with the author, 14 February 2006.

${ }^{75}$ Mark Baldwin, interview with the author, 14 February 2006.

${ }^{76}$ Malcolm Ross, correspondence to Mark Baldwin, 28 November 1983.
} 
These comments provide an edifying glimpse into Ross's mindset. His use of painting as a substitute for photography due to ease reveals his ability to operate in the medium; his view of it "simply as a means of obtaining images" highlights that for him the content of the image was more important than the method of obtaining it. But although an emphasis may be placed on the ends rather than the means, throughout his work Ross shows a desire to marry the formal with the conceptual, combining craft and content to create pieces which embrace both these aspects of artistic practice. In this, Ross's work complicates the claims of Donald Kuspit that the art-historic trajectory suggested by Duchamp has ultimately resulted in "the demise of the aesthetic experience" and the premature "end of art", 77 a reading which inevitably results in a narrow assessment of Duchamp's work. As Dalia Judovitz points out:

Duchamp's explicit rejection of painting as a purely visual medium whose purpose is to incite "visual euphoria" must be taken with a grain of salt. Duchamp's objections to painting are strategic, rather than purely oppositional. They are less a statement of denial of the significance of pictorial traditions, than an effort to rethink the legacy of painting in conceptual terms. $^{78}$

Indeed, while conceptual art and art concerned with formal qualities have been presented as diametrically opposed, even mutually exclusive, both Ross and Duchamp show that this opposition is not a given. ${ }^{79}$

\section{QUOTATION}

As suggested in my opening account of [Elam Studio Self-portrait] another key aspect of Ross's working practice is quotation, which, like humour, functions on several levels in his work. Whilst Ross was notoriously unforthcoming about the motivations or inspirations behind his art, close inspection reveals that it is peppered throughout with allusions and references to traditional art. Ross's archive contains a number of quotations in the most

\footnotetext{
${ }^{77}$ Donald Kuspit, The End of Art. Cambridge University Press: Cambridge, 2004, p i.

${ }^{78}$ Dalia Judovitz, Unpacking Duchamp: art in transit. University of California Press: Berkeley, Los Angeles, London, $\mathrm{p} 78$.

${ }^{79}$ For an example of Ross's work which successful marries craft with concept see my discussion of Untitled [High-heeled Pipe], pp74-77.
} 
literal sense, including hand written passages transcribed from books on art history, photocopied pages from sources relating to his various research interests, and sketches of well known art works; a book of stamp works in the collection of Douglas Wright features puns and word plays which also reference Giorgio de Chirico, Henri Matisse, Jackson Pollock, Marcel Proust and Jean-Paul Sartre. But his work employs quotation in less literal ways as well. Photographs included in Untitled (or $A++$ ) show Ross roughly approximating the poses of figures from famous paintings, while other works in his archive depict re-contextualised art-historical characters in unnerving circumstances; in both instances quotation is used to create humorous visual puns and imbue the works with multiple layers of meaning.

Quotation has a long tradition in art, the history of which has often been recounted in terms of a patriarchal lineage of influence. More recently, postmodern practitioners such as Barbara Kruger, Sherrie Levine and Yasumasa Morimura have employed quotation to subvert modernist notions of originality and expression and to question the formation of art's grand canon. Operating on the cusp of post-modern practice, Ross's early art-historical references seem more in keeping with this latter group's aims to challenge and destabilize, and his works can be viewed as precursors to those by a subsequent generation of conceptual practitioners. ${ }^{80}$ Other works of Ross's reflect a reappraisal of the art-historical canon from a homosexual perspective, an approach which strongly resonates with post-modern issues of identity and gender politics. For Ron Brownson, Ross's work of this type provides "a meta-commentary in a campy manner . . . used to cock a snook, but also to act as a diacritic on art history." ${ }^{81}$ Here once again the dual strands of humour and seriousness can be detected.

As his body of work developed, Ross increasingly quoted from his own back catalogue. According to Ron Brownson, ". . the works that he was doing

\footnotetext{
${ }^{80}$ Like Morimura, Ross's quoting sees him adopting the poses of well-known art-historical subjects and photographing them.

${ }^{81}$ Ronald Brownson, interview with the author, 6 November 2006.
} 
towards the end of his life were reflecting a lot of the work that he was creating at the beginning of his life." The result is an oeuvre in which works from different periods and media are interconnected via quotation. This constellational approach affords Ross the opportunity to interweave aspects of his own personal history with art history and colonial history, unifying various fields of interest in a single tableau. ${ }^{82}$ In quoting from his own sources at the end of his artistic trajectory, Ross highlights the increasingly solipsistic nature of his art practice whilst strengthening the claim that his work is best viewed as a life-long project.

${ }^{82}$ Ron Brownson, interview with the author, 6 November 2006. 


\section{'WARM AR'T FEELINGS/UNSUNG'}

Malcolm Ross and Art/History

While Ross's use of quotation is often subversive, humorous and provocative, it nevertheless provides an art-historical context for his work that he frequently refused to furnish via discussion. Yet if in quoting from past works he seems to accommodate, even encourage, a traditional monographic approach in which a chain of artistic influence can be traced, his aforementioned eschewal of the art-historical conventions of signing, dating and titling works deliberately complicates such an approach. Indeed, one of the most interesting aspects of Ross's employment of quotation is what it can be seen to reveal about his conflicting attitudes toward art history, and how he perceived his place within it. A number of the people interviewed during the course of this research testify to Ross's familiarity with, and reverence for, art history, whilst also pointing out that Ross did not like to discuss his work in this context. According to Roger Peters, "he was inscrutable, he . . wasn't particularly happy talking about the arts or the art-historical side of what he was doing., ${ }^{, 83}$ Bronwen Muir, a close confidant of Ross's during his honours year at Elam, states "I think he had a huge reverence and respect for art history," but later goes on to say:

I don't think that he would like for people to be waxing theoretically about [his work], or where it came from. And ... the art history aspect, which we were expected to write about ... I think that he found that self-indulgent. ${ }^{84}$

This view is further augmented by Anthony Green, Ross and Muir's art history professor at Elam. Green recalls that despite Ross always being polite and staying at his house the summer prior to his honours year, "[He] wouldn't do anything [in art history class] ... [he] conspired to remain silent, or to obstruct any possible discussion."

${ }^{8.3}$ Roger Peters, interview with the author, 6 September 2006.

${ }^{84}$ Bronwen Muir, interview with the author, 4 February 2008.

${ }^{85}$ Anthony Green, interview with the author, 8 February 2006. 
So what might Ross's reluctance to discuss his art and his refusal to participate in Green's art history class - juxtaposed with a readiness to repeatedly quote from art history — be seen to indicate about his attitudes towards the discipline? While his unwillingness to dissect his art in the company of others might in part be explained by his private and secretive nature, I suggest it also highlights an unresolved tension between his dual identities of artist and historian, which itself is just one symptom of a much larger and ever-present inner conflict.

Much of this inner conflict can be traced to Ross's troubled and complex relationship with his parents, a relationship which features prominently in Douglas Wright's account of him in Ghost Dance. Early in his account Wright highlights Ross's obsession with his parents and the perceived wrongs they inflicted, much of which seemed to spring from his inability to grasp written language at a young age. Wright writes:

When Malcolm was diagnosed as a backward reader in his first year at school, his father was outraged. As a pre-schooler Malcolm had ... a fascination with drawing, but words, to him, were mysterious. One at a time he could almost grasp them, but in regiments, with his father as their screaming general, they became incomprehensible, and all his father's biffs and clouts only made him long to be invisible. ${ }^{86}$

The problematic relationship between Ross and his parents will inform much of my commentary in this thesis, but what is pertinent in terms of the present discussion is that this conflict can to some extent be divided down the lines of images and words - and by extension - art and history. A conflict between these strands of creative pursuit, and a lingering longing "to be invisible", continued throughout Ross's adult life.

Whilst he seemed to be a natural artist, Ross clearly struggled with academic prose. His attempts at writing in this mode were mixed at best. Though a clever writer with a witty turn of phrase, Ross's tongue in cheek humour and questionable grammar did not always fit the criteria for published work, as witnessed by an article on the history of the New Zealand Society of Sculptors

${ }^{86}$ Douglas Wright, Ghost Dance, p 30. 
and Painters for Art New Zealand that was ultimately rejected. ${ }^{87}$ And yet, as mentioned previously, the majority of his archival material relates not to his art but to his historical research, and there is evidence that he valued this work even more than his artistic endeavours. According to Bronwen Muir, during Ross's thesis year he considered his work at Elam "play" and, even after long hours in his studio, in the evenings he would always find time to engage in what he considered his "serious" historical work. ${ }^{88}$ Incorporating both strands of Ross's endeavours, his archival remains reflect this conflict between art and history.

An intersection of Ross's written and artistic work can also be seen in a series of stamp works, from which the titles of this thesis's chapters are taken. In these works Ross breaks down words into their basic components, a stamp for each letter combining to form words and phrases which often subvert language in intriguing and revealing ways. Commenting on these works, and their relation to Ross's academic writing, Douglas Wright states:

I think he's at his best with language in those stamps when he's subverting language and punning, and to paraphrase what he said, he's taking a word and embarrassing the hell out of it . . . those one-liners are brilliant, and I think that those words are a riposte to the obsessive correctness of archival and historical writing. I think they are his answer to that really, and that when he tried to write in prose, he couldn't find a way to both satisfy his need to rebel against the form and use it. ${ }^{89}$

This seems an appropriate place to briefly discuss the work which I have adopted as the title of this chapter, 'Legendry Obscurity'. The phrase 'legendary obscurity' seems rather oxymoronic, begging the question to what extent is it possible to be both legendary and remain in obscurity? And yet applied to Ross - someone who was a notorious, almost mythical figure amongst his friends, but unknown on a wider, public scale - the phrase seems to fit nicely. As Douglas Wright highlights in Ghost Dance, to those

\footnotetext{
${ }^{87} \mathrm{He}$ did, however, have an article on Chris Booth published. See Malcolm Ross, 'Chris Booth's Nga Tamariki a Tane', Art New Zealand 30, 1984, pp 14-15.

${ }^{8 s}$ Bronwen Muir, interview with the author, 4 February 2008.

${ }^{89}$ Douglas Wright, interview with the author, 6 November 2006.
} 
who know of it "his 1971 thesis is legendary." pretentious that Ross makes such a claim for himself, the fact that he has misspelled legendary immediately rubs against any notion of self-importance. The extent to which this mistake is intentional is a moot point. As mentioned in my biographical account of Ross, he struggled from an early age with spelling, although even his mother, perhaps his harshest critic, finally conceded that "though the spelling is all your own, the meaning comes across without any ambiguity." However, regardless of intention, the effect is interesting. Having a title which includes a mistake certainly rubs against the grain of academic correctness.

In a number of the stamp works mentioned above Ross directly addresses his complex relationship to art/history. In one, De Chirico Versus Fish and Chips [Fig. 6], art and history are literally pitted against one another, the work seeming to beg the questions: How do artists ultimately fare in the ever changing tides of history? Is the famous Surrealist painter already yesterday's news? Two further works which speak closely to Ross's inner conflict and relationship to art history are In the Beginning Was Jackson Pollock and In the Beginning Was Jackson Pollock/Jackson Pollock Alcoholic [Figs. 7 and 8]. Here, with a remarkable economy, Ross evokes the cliché of the troubled genius who vacillates between the extremes of arrogance and self-doubt. Clearly referencing the well known life story of Pollock, a classic case of modern art-historical mythmaking if ever there was one, these works highlight aspects of the artistic temperament and the mythology of the 'alienated' artist that Ross critiqued but also, in many ways, embodied. There is a curious selfawareness at work in these and other examples from the stamp series, in which Ross's invocation of art history allows him to create tentative 'alliances' with kindred artists whilst also acknowledging the liberties and distortions which often accompany biographical information. In Pollock, Ross seems to see a figure he can empathise with, and yet, perhaps due to his own

\footnotetext{
${ }^{90}$ Douglas Wright, Ghost Dance, p 189.

${ }^{91}$ Ruth Ross to Malcolm Ross, I December 1969.
} 


\section{$D E C H I R I C O^{-}$ $V E R S U S$ \\ $\begin{array}{lllllll}F & I & S & H & A & N & D\end{array}$ \\ C $H I P S$}

Fig. 6. Malcolm Ross, De Chirico versus fish and chips, undated. Stamped ink on paper

Douglas Wright collection

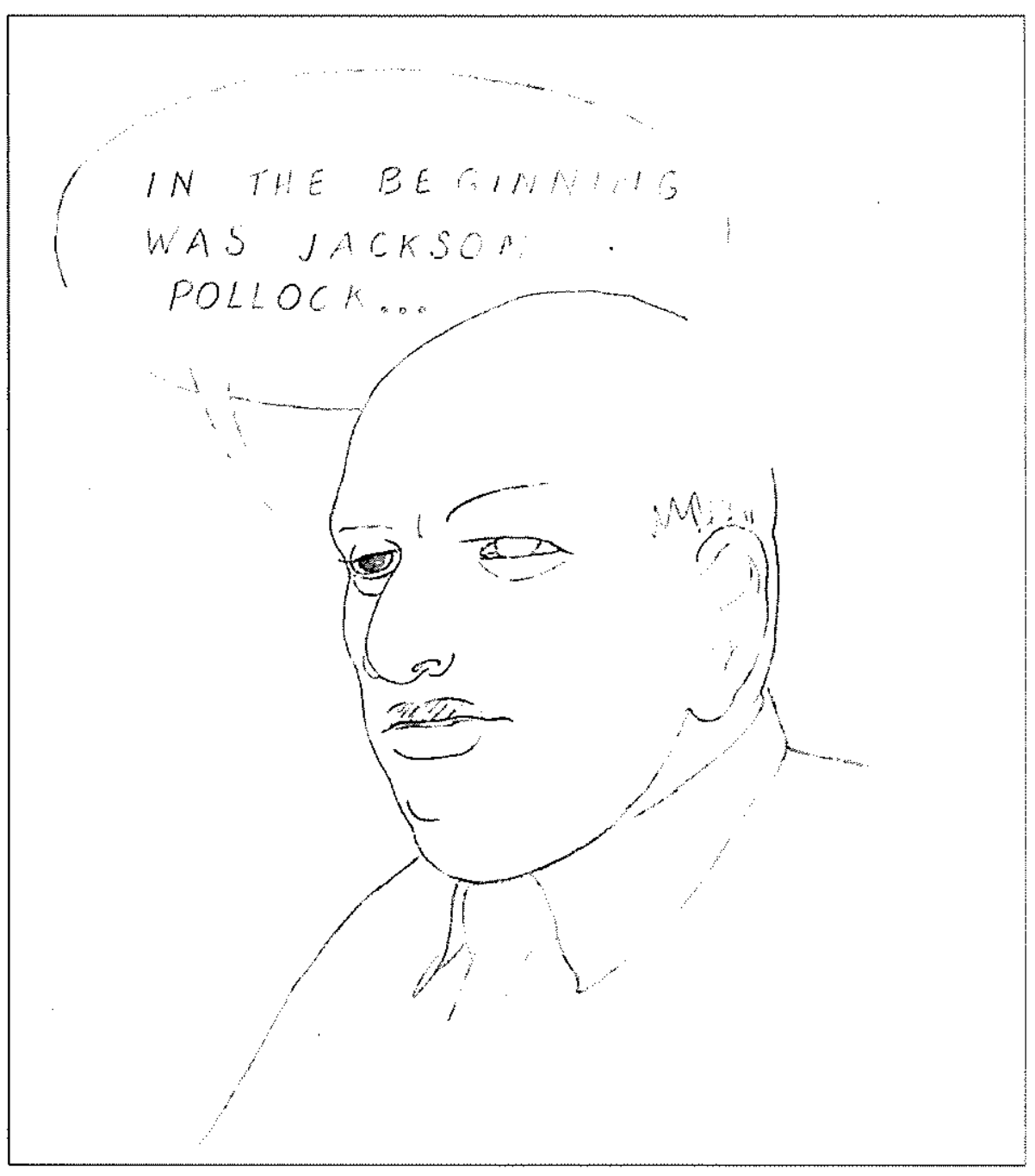

Fig. 7. Malcolm Ross, In the beginning was Jackson Pollock, undated. Ink on paper

E.H. McCormick Research Library, Auckland Art Gallery Toi o Tamaki 


\section{I $N$ THE B E- \\ G I N N I NG W A \\ $J A C K S O N$ \\ $P O L L O C K$}

\section{$J A C K S$ ON \\ $P O L L O C K$}

$A L C O H O L I C$

Fig 8. Malcolm Ross, In the beginning was Jackson Pollock / Jackson Pollock alcoholic, undated.

Stamped ink on paper

Douglas Wright collection 
self-aversion, there is an element of mockery involved also. As Wright poetically observes of Ross in Ghost Dance, "He has such a generous aversion to himself he extends it to others, then wants it back."92

Ross's reverence for history coupled with his self-loathing meant that ultimately he was - at best - ambivalent about his own place within it. Much like Pollock perhaps, despite being critical of others' works he also felt unworthy. This provides one possible explanation as to why Ross often destroyed his "finished" work, feeling that it would not be able to withstand the ultimate judgement of time - however, his documentation of much of this work does confuse this claim. In choosing not to sign, date and title his works, he refused to "sign off", denying their completion. Commenting on Ross's attitude to dating his work, Ron Brownson notes:

Some artists do want to inscribe their works with their name, date, the period ... [Ross] had an absolute resistance to that. He wasn't actually so interested in chronology as he was in the coherence of the subject. It was all part of his work whether it was 1978 or 1984 didn't really concern him. That was, to me, a really conscious move on his part not to conceive of his work in a temporal manner. ${ }^{93}$

Not "conceiving of his work in a temporal manner" can be seen to have two consequences. On one hand this approach strengthens the claim that his work is best viewed holistically. But it also complicates the work's easy assimilation into official records, making an investigation of Ross's art problematic even though his own historical research ensured he was aware of the advantages of well-ordered and thoroughly-labelled collections. Once again it seems Ross's "aversion to himself" has been extended to others, this time to any potential researcher of his archives. However, his archiving does see him utilising the tools of history to counter his self-destructive impulses, to find a novel way to marry together art and history.

Ross's work can also be seen to straddle the divide between art and history in other ways. Operating in a terrain in which art and history overlaps, Ross's

\footnotetext{
${ }^{92}$ Douglas Wright, Ghost Dance, p 28.

${ }^{93}$ Ron Brownson, interview with the author, 6 November 2006.
} 
life-long project negotiates what Hal Foster has identified as a "fault-line" running through art history. Foster argues that the art historian's dual roles of demonstrating the autonomy of art whilst accounting for its socio-historical context have created an inherent tension in the discipline. ${ }^{94}$ In many ways Ross's work seems to resonate with Foster's approach, and this art-historical fault-line mirrors the aforementioned tensions and paradoxes that permeate his oeuvre. On one hand Ross's secretive practice might be seen to embody a form of artistic autonomy; by not exhibiting his work publicly his art is separated, at least to some degree, from the socio-historical context in which it was created. But on the other hand, the degree to which his life experiences and responses to social issues are infused into the work clearly complicates this "autonomy".

Mark Baldwin makes some interesting observations relevant to this point. One of the first things Baldwin mentioned to me about Ross was that, despite cohabiting together, Ross fiercely guarded his work, which was usually housed in a room of its own. If Ross wanted to show Baldwin a particular piece, he would be ushered in with strict instructions only to look at the item in question - glancing around the room was forbidden. Whilst my claim that Ross's art should be viewed as a life-long project may have the effect of conflating the artist's life with his work, Baldwin complicates this assumption when he says:

... [Ross] as a person, and his work, almost weren't the same thing. He has something which he's defined as his work ... and then there is him as a person dealing with the realities of the world. So there are two things there actually ... they can't be mutually exclusive, but they are different ways of thinking about him. And him as a person, and the things that happened to him, that's what fed [his work]. But how he reacted to you, and how he got on with [his work] were slightly different. ${ }^{95}$

What Baldwin's comments highlight is another example of the many paradoxes that flourish in Ross's oeuvre, which contains fault lines that extend

\footnotetext{
${ }^{24} \mathrm{Hal}$ Foster, 'Antimonies in Art History', pp 83-103.

${ }^{95}$ Mark Baldwin, interview with the author, 14 February 2006.
} 
beyond the art-historical dilemma identified by Foster. However what Foster's approach reflects is a novel approach to art history in which a figure like Ross seems to have relevance.

Indeed, one consequence of considering Malcolm Ross as an art-historical subject is that the numerous questions raised by his working methods, artistic output and (lack of) public reception afford the opportunity to reappraise the discipline at a time when a number of its traditional roles have been rendered problematic. At the top of this list of questions is that most enduring of chestnuts: What can be considered art? Can Ross's sketches, notes and ideas be viewed as an integral part of his body of work? Can Ross's archival remains be considered to amount to an oeuvre at all, and are they interesting enough to warrant posthumous resuscitation? Is an artist who failed to achieve a public reputation, and whose works have no established market value, worthy of art-historical analysis at all?

The responses to these questions will undoubtedly be many and varied, but I believe they provide a litmus test on how broad or accommodating an individual believes art history should be. In challenging a conventional approach to art production and reception, Ross's work mirrors critiques levelled at the discipline by a range of artists, contemporary art historians and cultural theorists aiming to widen its scope. If Ross can be seen to have a place in art history, it is primarily due to the fact that there has been a call to expand the discipline in order to accommodate artists whose work challenges its pre-existing boundaries. Throughout this discussion I will argue that it is the problems that Ross's work poses to an art-historical account of him combined with the quality of his work and the conceptual strength of his ideas - that grant him an ongoing currency in the current climate of art practice and art theory. 


\section{'MY NA'TIVE SUBURB GOODNIGH'T'}

\section{Malcolm Ross and New Zealand}

He had an almost chemical aversion to leaving here. It just seemed to me he couldn't exist elsewhere.

- Douglas Wright on Malcolm Ross'

Even the most cursory examination of Malcolm Ross's work reveals a deep engagement with New Zealand history and culture. This section of my thesis will chart the importance of place in Ross's body of work, examining the various ways in which New Zealand locations, materials, influences and connections infuse his art with a distinctly local flavour. In doing so, my investigation will seek to further illuminate aspects of the artist's personality and practices, whilst also providing a reflection on, and at times a reconsideration of, aspects of art practice in this country.

As indicated by Wright's quote which begins this chapter, Malcolm Ross never left New Zealand. In contrast to the tradition of expatriate artists seeking education and validation overseas, Ross's 'chemical aversion' ensured that he remained on these shores his whole life. The inclusion of a copy of Terry Smith's oft-cited article 'The provincialism problem' in his archive suggests that Ross was well aware of the problems and pitfalls of an artistic career at the geographic and cultural margins of the world, yet his unique approach to art making suggests that he found a freedom in operating from such a place. As a consequence of his lack of participation in the local scene he operated in a space even further removed from the already provincial position of the New Zealand art world. ${ }^{2}$

In many ways Ross might be considered an archetypal kiwi. With his do-ityourself attitude and inventive use of local materials; his laconic, dead-pan sense of humour and egalitarian suspicion of anyone who felt superior or seemed pretentious; and his appreciation of alcohol and rugby, in many ways

\footnotetext{
'Douglas Wright, interview with the author, 6 November 2006.

2 Terry Smith, 'The provincialism problem', ArtFortum, September 1974, pp 54-59.
} 
Ross conformed to well-established national traits. And yet it is also clear that in certain respects Ross was on the fringes of 'mainstream' New Zealand. His experimentation with psychotropic drugs (according to Wright he was the third person in New Zealand to be arrested for the possession of LSD), and homosexuality are just two factors that might locate Ross in local counterculture. ${ }^{3}$

I have already discussed at length Ross's inner conflict, and his often contradictory attitudes towards New Zealand provide another example of his impulse to love and hate in equal measures. Time and again Ross's body of work displays a deep reverence for - and sustained interest in - all things Maori, and his knowledge of arcane indigenous customs and cultural practices is clearly evidenced in his archival material. As Douglas Wright highlights in Ghost Dance, Ross was raised in predominantly Maori communities, and according to Mark Baldwin it was not until the age of six that he realised he was not Maori himself. ${ }^{4}$ What effect this realisation may have had will ultimately remain in the realm of conjecture; however, I believe it is fair to describe Ross as a self-appointed 'half-caste', someone who felt he belonged to neither Pakeha nor Maori culture completely. In this, Ross seemed to consciously position himself as an outsider on the margins of society.

Ross's love of Maoritanga and appreciation of our (comparatively) egalitarian culture was mitigated by his disdain for the aspects of New Zealand society he found stifling, close-minded and oppressive. According to Vicky Hamill, while Ross went out of his way to befriend people he believed were marginalised by society, particularly Maori and Pacific Islanders, he also felt "a separation from the redneck heterosexual New Zealanders around him."

This observation illustrates my central contention that Ross's inner tension was projected onto, and reflected in, his contradictory attitudes towards this

\footnotetext{
${ }^{3}$ Douglas Wright, Ghost Dance, p 188.

${ }^{4}$ Mark Baldwin, interview with the author, 11 August 2006.

${ }^{5}$ Vicky Hamill, email to the author, 8 July 2007.
} 
country. When I asked about Ross's relationship with New Zealand, Douglas Wright's reply was revealing:

Well I know in Inland, where I had Pita Rudus say, "Oh God, I hate this fucking country, the grass is so green, the sky is so blue, ba ba black banks of grass, have you any fully adjustable shelves and door and cabinet," he loved it, he totally loved it. He hated and loved [New Zealand] . . you know the classic love/hate thing. ${ }^{6}$

Ross's love/hate relationship with this country will provide one theme for this section of my thesis, however my analysis of Malcolm Ross as a New Zealander will utilise several approaches. Beginning with a brief analysis of the materials and subject matter Ross utilised in his art practice, I will suggest that his idiosyncratic approach to the crafting of his work reveals much about the influence of place in his oeuvre.

I will then seek to highlight aspects of Ross's relationship with his teacher and mentor Colin McCahon. If I posited Duchamp as an artistic father-figure in my introductory chapter, here I will argue McCahon performed a similar function, and will explore the contentious issue of McCahon's influence on Ross's decision to refrain from exhibiting his work. I will analyse correspondence from McCahon to Ross, as well as looking at several of Ross's works which make direct reference to McCahon's work and influence, exploring what I believe, in tandem, they reveal about the relationship between the two artists.

One of the most readily identifiable characteristics of Ross's art is the wide variety of materials used in it. This is in part due to the range of media utilised by Ross, but one common factor in this diverse output is his use of everyday materials far removed from those traditionally associated with the fine arts everything from modified vacuum cleaners to impaled telephone directories appear in his oeuvre. This approach conforms to two of the key aims of postobject practice, the eschewing of the 'precious' art object and a narrowing of the gap between 'art' and 'life'; but a further consequence of this method is an incorporation of distinctly local materials and artefacts into his work. Often

\footnotetext{
${ }^{6}$ Douglas Wright, interview with the author, 6 November 2006.
} 
recycling everyday objects from his immediate environment, Ross's art is littered with markers of his New Zealand identity throughout.

Remembering his first impressions of Ross's working space in New Plymouth in 1970, Paul Hartigan's comments echo the sentiments expressed above. He recalls:

There would be all kinds of things [in Ross's New Plymouth flat] Malcolm's favourite materials: number eight wire, fishing twine, things that were quite common to us all as New Zealanders. Newspapers, telephone books, 4 by 2 , bug nails, hammers, clotheslines, corrugated iron. He would utilise all these materials but reinvest in them, invest a new personality, a new take. ${ }^{7}$

Referring to a range of work which would provide the basis for much of the conceptual sculpture Ross carried out at Elam the following year - the items mentioned can be seen repeatedly throughout his thesis - these comments highlight the quotidian nature of Ross's favoured materials and their familiarity to the average New Zealander. Number eight fencing wire, fishing twine, chicken-coop netting and corrugated iron are materials which, whilst not by any means unique to New Zealand, are intertwined with our colonial heritage and national identity in a way that I would argue is quite idiosyncratic, and thus have a resonance here that is, to some extent at least, culturally specific.

Hartigan's observations are reinforced by Bronwen Muir, who remembers with particular fondness Ross's idiosyncratic use of the phone book in several works. She recalls:

He was using common place materials, not specialised, fine arts materials, or even materials that are used in the fine arts process. He was using them in a different way. It was almost like antiaestheticism . . like he was turning his nose up at all of that ... the telephone directory, there were just piles of them left around the art school, and he saw them, they weren't being used, and he put them to use. And it was the fact that they were ordinary, and he used them in an extraordinary way to focus on something that is about all of us

\footnotetext{
${ }^{7}$ Paul Hartigan, interview with the author, 7 November 2006.
} 
really, it was that we're all crucified. It was using a universal format in a new way. ${ }^{8}$

The work Muir here refers to is Crucified Directory, part of Untitled (or $A++$ ) [Fig. 9]. As suggested by Muir's comments, one of Ross's aims in utilising items familiar to everyday New Zealanders may have been to lessen any perceived gap between 'high' and 'low' culture; to dislodge art from the proverbial pedestal it had been seen to occupy - which Crucified Directory neatly encapsulates. ${ }^{9}$ As she notes, there is an element of anti-aestheticism in such work which could be traced to Duchamp, but which also could be seen as an appeal to the common person. Indeed, in many ways Ross's work, particularly that which dates from early on in his career, seems aimed at the everyday New Zealander - he creates a form of idea-based art that might amuse and intrigue even those not usually enamoured of contemporary practice, let alone conceptual art. Viewed in this light, the fact that he never exhibited this work on a wider scale (despite encouragement to do so) does seem paradoxical and self-defeating, but as highlighted already, this is typical of Ross's practice. Once again a contradiction emerges: there is an element of the everyman in Ross, even though those who knew him often refer to him as the most unique individual they ever knew. ${ }^{10}$

One exception to Ross's reticence to display his work provides an intriguing insight into his attitudes towards its reception. It seems that the one audience Ross actually encouraged and arranged to view his honours year's work was not his peers or teachers, but rather a group of school children, and their subsequent encounter with it is revealing not so much for their reaction to the work, as Ross's disappointment with their lack of reaction. According to Muir:

Malcolm invited . . . a class of students into the studio, because he was interested in their reaction. And I think he was really baffled and a bit

\footnotetext{
${ }^{8}$ Bronwen Muir, interview with the author, 4 February 2008.

${ }^{9}$ This is also seen in my earlier discussion in the chapter 'Legendry Obscurity' regarding Untitled [Bull/bullshit].

${ }^{10}$ For instance, Douglas Wright and Richard Wolfe, among others, have categorised Ross in this way to me.
} 


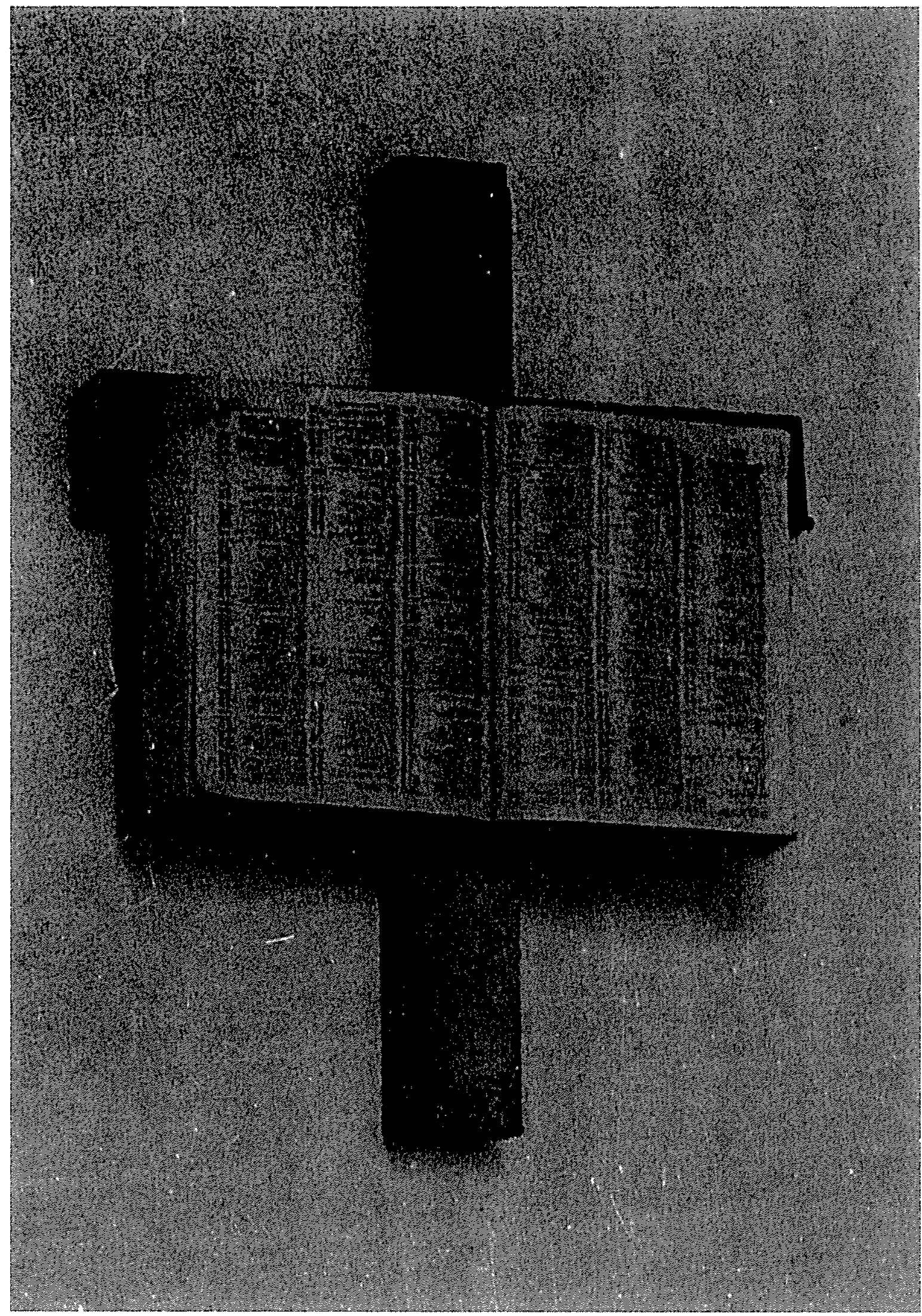

Fig. 9. Malcolm Ross, Crucified Directory, 1971

'Fact', from Untitled (or $A++$ ) 
disappointed because the kids just stood around and looked, and he expected them to be much more hands-on and interacting. "

Ross's desire for school children to interact with his work in a hands-on way reinforces the notion that he was trying to remove art from the pedestal, to create work that could engage the viewer in a fun and playful way. ${ }^{12}$ It also provides a further point of difference from many of his peers at Elan who seemed more interested in generating critical and cerebral responses to their work. I suspect that Ross, reasoning that the children would not be as conditioned in responding to art as his peers, would have a more visceral, less self-conscious encounter with it. His disappointment probably stemmed from the fact that the children, in the context of a school field trip at least, were more polite and reticent than he had hoped for, but this may also have made him question whether his art operated in the way that he hoped. As Muir points out, "[the children's reaction] reflects the way the kids had been taught; it was a sort of reverence. It was not what he really expected. But then, to me, that only just shows he didn't know if other people really saw what he was doing." ${ }^{\prime 3}$ The fact that this, perhaps the only instance where Ross encouraged an audience to engage with his work, did not have the desired outcome may also have contributed to his reluctance to exhibit in the future.

One work which the school children would have encountered in Ross's studio which brings into focus many of my points about his sticks and strings approach is Inside Out-house (1971) [Figs. 10 and 11]. Perhaps Ross's tonguein-cheek answer to the post-object installation, here he creates a room within his Elam studio from a $4 \times 2$ wood frame and corrugated iron. The result is a rather haphazard and shoddy construction that looks like it would be more at home on a farm paddock than in an art gallery, and yet I think this work which appears to have been included in Ross's thesis only as an afterthought

\footnotetext{
${ }^{11}$ Bronwen Muir, interview with the author, 4 February 2008.

12 It also highlights Muir's claim that for Ross, the creation of this work was considered to be play. Additionally, I believe it suggests that his work could operate both viscerally and conceptually, and thus had the potential to be appreciated by a wide range of people.

${ }^{13}$ Bronwen Muir, interview with the author, 4 February 2008.
} 
- is interesting on a number of levels. ${ }^{14}$ It suggests much about Ross's irreverent, humorous approach; his secretive nature; his identification as a New Zealander; and his ability to, as Paul Hartigan identifies, utilise common materials but "invest them with a new take", to marry the profound with the banal.

Ross was by no means unique in incorporating local materials in art installation at this time, and Jim Allen's New Zealand Environment No 5 (1969, Govett-Brewster Art Gallery Collection, New Plymouth) [Fig. 12] provides an interesting comparison to Inside Out-house. Both works create spaces within spaces - in Allen's case, an installation inside an art gallery; ${ }^{15}$ in Ross's, a room inside his Elam studio. Both are designed to be experienced phenomenologically - rather than works on 'pedestals', both invite, require even, the physical experience of a 'spectator' or occupant. Additionally, both incorporate materials strongly linked with New Zealand - wool, sawdust and hessian in the case of Allen's installation, the aforementioned corrugated iron and 4 × 2 frame in Ross's.

Whilst incorporating local materials and, via the title, making a direct reference to this country (highlighting that the work is of this place in a way a landscape painter might), New Zealand Environment No 5 still strongly reflects the imported concerns of cybernetics and global conceptualism. While some of Ross's honours year work might also be seen to echo current artistic trends, for the most part he was careful to maintain independence from outside influences, and I would argue Inside Out-house presents an extremely idiosyncratic (and distinctly local) take on the post-object environment. Ross's

\footnotetext{
${ }^{14}$ Inside Out-house appears towards the end of Ross's thesis, in a section dedicated to "various bits and pieces" not deemed to fit in elsewhere. Its title and description are in Ross's distinctive hand-writing, rather than typed as the rest of the thesis, suggesting a lastminute inclusion.

${ }^{15}$ New Zealand Environment No 5 was originally exhibited at the Barry Lett Galleries in 1969, followed by installation as a part of the Fourth Mildura Sculpture Triennial in 1970; it was subsequently purchased by John Maynard for the Govett-Brewster Art Gallery co llection. See Christina Barton's 'The Last Small World: Jim Allen's New Zealand Environment no 5' Midwest 1, 1992, pp 29-31 for further discussion of the installation's position as a 'crucial work' of New Zealand post-object art, which exemplifies 'sculpture's critical re-orientation from object to situation'.
} 

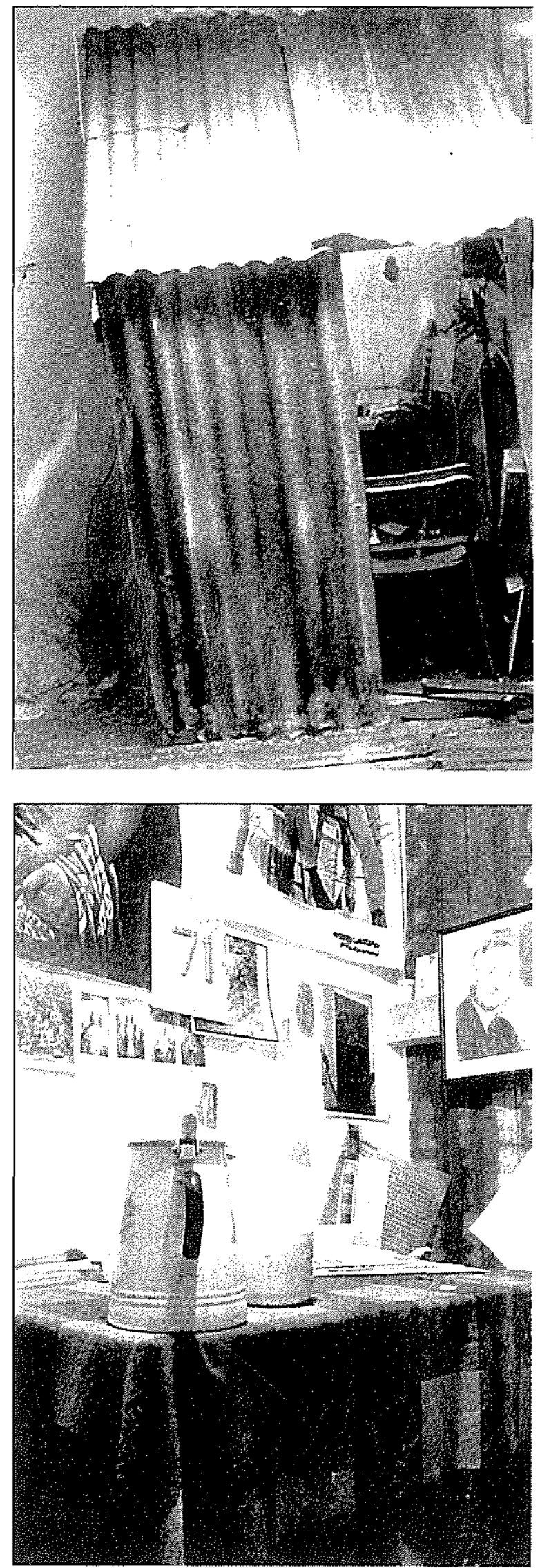

Figs. 10/11. Malcolm Ross, Inside Out-house [interior and exterior views], 1971 'Facts', from Untitled (or $A++$ ) 


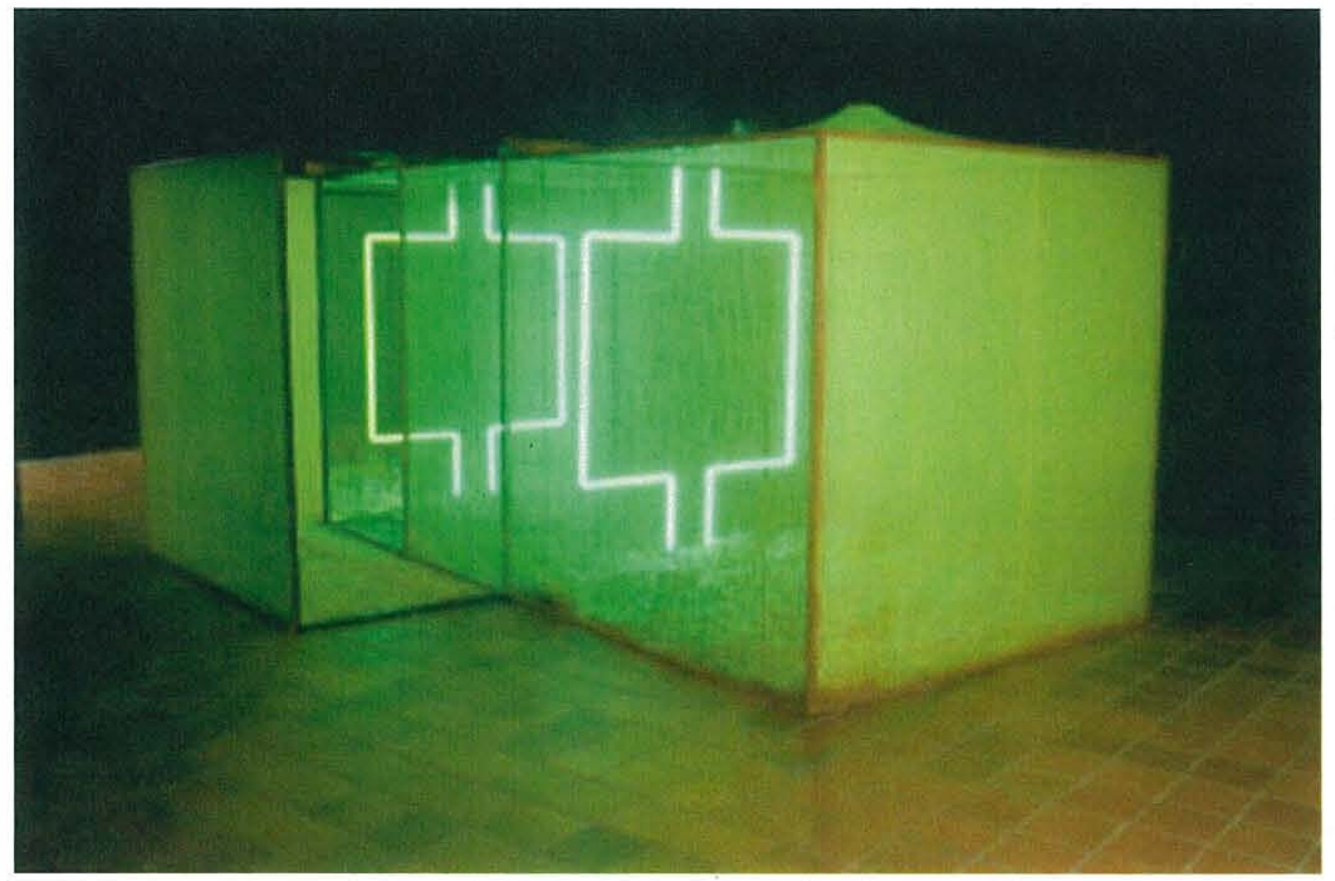

Fig. 12. Jim Allen, New Zealand Environment No 5, 1969

Mixed media installation

Govett-Brewster Art Gallery collection 
sensibility, which saw him avoid mimicking current trends, is reflected in the opening remarks to his thesis, where he acknowledges anyone who "thinks they may have had the idea first." 16 In contrast to his own approach, Ross seems to have felt that many of his contemporaries at Elam, including Allen, were merely importing ideas from overseas and parroting them in their own work. Ross's archive contains a brief overview and assessment of Allen's career which provides some intriguing insights into key differences in approach between the two. He writes:

As a sculptor, [Allen's] readiness to switch styles at the drop of a hat has caused uneasiness ... The entrepreneur returning from overseas with the new idea and flogging it for all he is worth - whether Frisbees, conceptual art or dead horses - is one of the great New Zealand archetypes: we have one in sculpture. His critics would maintain that common decency should confine one to one such importation in a lifetime. Jim Allen's real offence was to go on doing it, time and again. ${ }^{17}$

I am not so interested here in analysing the validity of Ross's critique of Allen, but instead wish to consider what his words might, by implication, reveal about his own attitudes. Although earlier in this same account Ross acknowledges Allen's historical importance, stating "that he is an important figure by almost any criteria one wishes to apply," there is a clear implication that he believes Allen is guilty of relying too much on the ideas of others in his own practice, and is only too willing to change his style to fit the fashions of the day - something Ross continually attempted to avoid. ${ }^{18}$ If Allen conforms to the New Zealand archetype of the entrepreneurial, opportunistic importer, Ross might conform to another archetype: namely the backyard inventor that exemplar, par excellence, of 'kiwi ingenuity'. If Allen might be characterised as earnestly exploring the implications and issues of global conceptualism, Ross can be seen as an antipodean iconoclast quick to mock

\footnotetext{
${ }^{16}$ Malcolm Ross, Untilled or $A++$, unpaginated.

${ }^{17}$ Malcolm Ross, Jim Allen, from the Malcolm Ross Archive, E.H.McCormick Research Library, Auckland Art Gallery.

${ }^{18}$ Mark Baldwin's earlier quoted observation - that Ross had a desire to constantly do the opposite of what was fashionable - reinforces this point.
} 
the perceived self-importance of such an approach. ${ }^{19}$ In comparison to $\mathrm{New}$ Zealand Environment No 5, Inside Out-house seems positively amateur in presentation, and much more irreverent in intent. As mentioned above, the work is a classic example of Ross's "sticks and strings" approach, and he humorously highlights the shoddy nature of the construction when he suggests in the documentation of the work that "the list to port is a photographic illusion." 20

Humour is also clearly present in the work's punning title. On one hand Inside Out-house references the outdoor lavatory (perhaps an example of the type of pun which Ross refers to in the introduction to his thesis as a "groaner"), but the title also invokes the notion of subversion: if something is inside-out it is commonly thought to be in opposition to conventional wisdom, as contrary to the way something is customarily done. Inside-out is an apt metaphor for Ross's whole career, which in so many ways is oppositional to the norm. This theme is given further resonance by the work's documentation in Ross's thesis. Both interior and exterior views are presented, even though in this case the 'exterior' view is still, in a sense, an interior shot. This conceptual loop in fact highlights that Inside Out-house is a work which could be considered to further separate Ross from his contemporaries at Elam. It effectively provided a refuge within a refuge - his studio space already guarded by padlocks with "Get lost" written on the outside, here he creates an additional degree of separation from the outside world, and provides a further example of his reclusive nature.

It is interesting to note that in the description of the interior of Inside Outhouse which accompanies its photographic documentation, Ross highlights the presence of a depiction of Michael Joseph Savage on the wall. Savage, the

\footnotetext{
${ }^{19}$ Ross's sensibility reminds me of Michael Dunn's characterisation of Paul Beadle, the first Professor of Fine Arts at Elam during Ross's enrolment. Dunn writes: "The witty irreverence of Beadle in his art ... was out of tune with the deadly earnestness of much Elam post-object art." Michael Dunn, 'Paul Beadle', in Nicholas Tarling (ed) Auckland Minds and Matters, University of Auckland Press: Auckland, 2003, pp 20-31.

${ }^{20}$ Malcolm Ross, Untitled or $A++$, unpaginated.
} 
Labour prime minister between 1935 and 1940 who was chiefly responsible for the creation of this country's welfare state, appears as a benevolent presence, and it is interesting to note that this is the only item signalled out for mention by Ross (although the walls are also decorated with numerous other items, including what appears to be a Beatles poster and, intriguingly, the only presence of Ross's Untitled [Self-portrait with Halo] in his thesis). ${ }^{21}$ Another key marker of Ross's New Zealand heritage, the photograph of Savage also suggests Ross was left-leaning in his political allegiances, and it seems salient to highlight that while he disposed of much of his honour's year's work, the photo of Savage remained in his possession for many years. Vicky Hamill recalls that when she met Ross, circa 1976, "M.J. Savage watched all the goings-on [of his flat] from the wall."22

Inside Out-house is just one example amongst numerous others in Ross's oeuvre that highlights the way his work is inextricably linked to his nationality. This is not surprising given that, according to Douglas Wright, Ross "always said . . . he thought overseas was just a big pretend, and that people went on a plane and hid over the horizon, and sent pretend landscapes and there was nothing really there." 23 Such a view reveals much about Ross's insular existence, and suggests that for him, New Zealand was the only 'real' landscape. This view helps explain why although many of his fundamental ideas might be considered universal, capable of being adapted to a range of contexts, the form they took typically incorporates, at the very least, indexical traces of his local culture. As Wright's comments above highlight, in many ways for Ross the local was the global. Consequently Ross's work seems distinctly 'New Zealand', in a way that the well-travelled Marcel Duchamp's seldom seems specifically French. For example Duchamp's 3 Standard Stoppages (1913, The Museum of Modern Art, New York) highlights the arbitrary nature of measurement, but other than the fact that it is a metric metre

\footnotetext{
${ }^{21}$ For a discussion of this work see 'I'll still be here when you're gone: the archival strategy of Malcolm Ross', Reading Room 1, 2007, pp 175-180.

${ }_{22}$ Vicky Hamill, e-mail to the author, 23 January 2007.

${ }^{23}$ Douglas Wright, interview with the author, 6 November 2006.
} 
rather than an imperial foot that is being deconstructed, it does not appear to be culturally specific. A work which resonates with 3 Standard Stoppages is Ross's Facts: Graphics: New Plymouth topographical inch to mile sheet (1971) [Fig. 13], in which a map of New Plymouth is reconfigured and arranged as squares of an ersatz chess board in order to deconstruct and expose the conventions of cartography. Here immediately the title inscribes the work with a geographic specificity.

As indicated in these examples mentioned above, Ross's 'antipodean' attitude extended beyond the materials and subject matter utilised in his work, and can be seen in his approach to hand crafting his work - he revelled in being "a sticks and strings man. ${ }^{24}$ Indeed, Ross seemed to approach the manufacturing of his work in much the same way as a pioneer settler would have approached taming the land - with whatever tools and skills he could muster, and with whatever materials he had at his disposal. Remembering Ross's approach to crafting his work, Bronwen Muir recalls:

I would think, "How amazing to have the ability to come up with so many ideas," it was just this huge flow. . . the ability to think of something, and then to go about making it. . . everything was handson, he'd do it himself. ${ }^{25}$

So far my discussion of Ross as a New Zealander has centred primarily on the sculptural work created in his honours year, however now I will turn my attention to the impact Ross's undergraduate education at Elam had on this, and other, aspects of his work. Notably, I wish to bring into focus the influence of his teacher and mentor, Colin McCahon.

\footnotetext{
24 'Antipodean' functions as a pun here, as both definitions of the word - pertaining to Australia and New Zealand and also denoting something which is diametrically opposite - are, I believe, pertinent to a description of Ross.

${ }^{25}$ Bronwen Muir, interview with the author, 4 February 2008.
} 


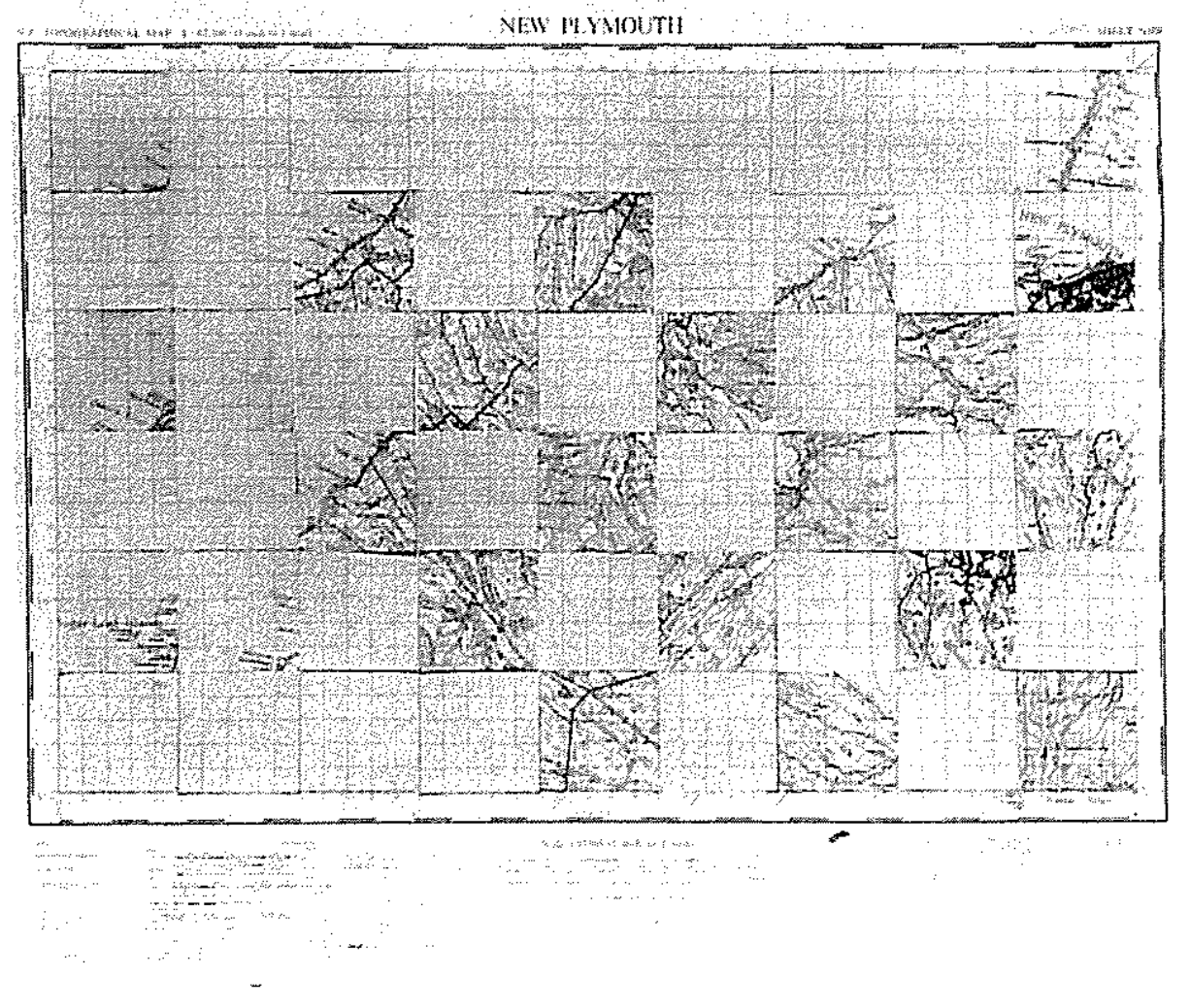

Fig. 13. Malcolm Ross, New Plymouth topographical inch to mile sheet, 1971

'Fact', from Untitled (or $A++$ ) 


\title{
¿AND ALL THE PEOPLE SHALL STONE HIM'
}

Colin McCahon and Malcolm Ross

\begin{abstract}
More than anything else, McCahon admired people who wanted to understand the spirit of our culture . . the zeitgeist. That's certainly something that Malcolm, perhaps as much or if I might say, more than his cohorts had the intelligence and the brilliance to be able to be incisively clear about.

- Ron Brownson ${ }^{26}$
\end{abstract}

The relationship between Malcolm Ross and Colin McCahon is an intriguing, yet to some extent inscrutable one. Almost invariably Ross's circle of friends comment on the importance of his interaction with McCahon, the man who has been described as Australasia's greatest painter. ${ }^{27}$ Yet most also acknowledge that they were not directly privy to the relationship between the two. Some contend that McCahon was instrumental in influencing Ross's decision to refrain from exhibiting, while others argue this is an unfair, inaccurate viewpoint.

Certain facts about the relationship between the two can, however, be deduced: Ross was a student in McCahon's painting class at Elam during the late 1960s. McCahon would go on to tell a number of people, including Bronwen Muir and Ron Brownson, that Ross was one of his most talented students, one who had more creative ideas than anyone he'd ever taught; and, for a time at least, Ross and McCahon drank together and conversed about art on a regular basis. ${ }^{28}$ Indeed, as was mentioned earlier, it may have seemed that the two forged a friendship based on a mutual appreciation for art and alcohol. At some point during this period in the early 1970 s, and quite possibly after one such drinking session, Ross stole McCahon's letterbox. Ross claimed that McCahon stole the idea for his Cloud series from one of Ross's paintings of numbered clouds, but according to Douglas Wright, he was not offended or

\footnotetext{
${ }^{26}$ Ron Brownson, interview with the author, 6 November 2006.

${ }^{27}$ Agnes Wood, Colin McCahon: The Man and the Teacher, David Ling: Auckland, 1997, p 13.

${ }^{28}$ Ron Brownson, interview with the author, 6 November 2006. Bronwen Muir, interview with the author, 4 February 2008.
} 
affronted by this; rather, he was happy to have "given the master an idea."29 And, whether true or not, Ross did tell others, including Douglas Wright and Paul Hartigan, that McCahon was instrumental in shaping his decision to operate at one remove from the art world. It also seems fair to say that Ross's view of McCahon reflected his love/hate relationship with New Zealand. According to Douglas Wright:

[Ross] said things like that "it was one in the eye for New Zealand because they wanted a great painter and they got one, but they got god too, and fuck them." And they wanted something, but they got what they didn't want as well . . he liked that about McCahon. ${ }^{30}$

Perhaps the best place to begin an examination of the mentor/protégé dynamic between McCahon and Ross is to scrutinize the existing first-hand evidence of their friendship, which is present in the form of correspondence from McCahon to Ross held in McCahon's archive, housed in the E.H. McCormick Research Library at the Auckland Art Gallery. Consisting of just two letters dating from early 1972, when Ross had moved to Wellington after completing his honours year at Elam, the letters provide a glimpse into the type of conversations the two would likely have engaged in during their notorious drinking sessions. Like much of the personal correspondence which Ross deposited in various archives around the country, here the researcher is presented with only one facet of a two-sided dialogue; and yet several intriguing insights can be gleaned nonetheless.

It is implied in these letters that they are a small fragment of a larger body of correspondence: McCahon begins the first letter, dated 8 March 1972, by apologising for his belated reply to an earlier letter of Ross's for instance. The degree of familiarity between the two is suggested by McCahon's invitation to "ring, come round, drop in anytime", and in an example of the paternalistic tone which is present in both letters, McCahon goes on to encourage Ross's study at Library School in Wellington, stating "Hope the school works out for

\footnotetext{
${ }^{29}$ Douglas Wright, interview with the author, 6 November 2006. Ross seems to have been referring to McCahon's Cloud series painted in the mid-1970s.

${ }^{30}$ Douglas Wright, interview with the author, 6 November 2006.
} 
you, I feel it should." "3l Here McCahon seems genuinely empathic with Ross's situation and sensibilities.

The second letter, dated 27 March 1972, provides some fascinating clues to the nature of their friendship. McCahon starts the letter by acknowledging previous correspondence from Ross, stating that it was good to receive it even though, "I knew the ordeal of a reply to you was going to be the inevitable result." 32 McCahon's comments here are intriguing - why would the reply to Ross's letter be an ordeal, and why was McCahon happy to receive the letter if this was the case? Without being privy to both sides of the conversation, any answer to these questions will of course be speculative, but I believe what this exchange suggests is that the relationship between the two was one where each freely questioned and challenged the other, where an open and critical exchange of ideas was possible, even if confronting. This reading is given some credence by Ron Brownson's comments:

Colin definitely admired what Malcolm did and recognised that Malcolm had a unique talent. Colin McCahon told me that. Colin McCahon told other people that. Colin McCahon told Malcolm that. But Colin was always someone who admired people who were doing things that were completely opposite from himself. He admired those people the most. ${ }^{33}$

Part of the 'ordeal' may have been due to Ross raising a number of questions relating to McCahon's practice in an earlier letter that the elder artist was reluctant to talk about. In the letter he discusses an unnamed painting that Ross must have enquired about in previous correspondence. McCahon's reply mentions that while he initially hated the painting - a reproduction of which Ross is indicated to have included in his previous letter - he has since grown to like it. McCahon highlights that the painting is a 'variation' of his wife Anne, not a 'strict portrait', which he only painted early on in his career.

Given that the two would subsequently come to 'cohabit' in the same archive,

\footnotetext{
${ }^{31}$ Colin McCahon to Malcolm Ross, 8 March 1972. Colin McCahon Archive, E.H. McCormick Research Library, Auckland Art Gallery Toi o Tamaki.

${ }^{32}$ Colin McCahon to Malcolm Ross, 27 March 1972. Colin McCahon Archive, E.H. McCormick Research Library, Auckland Art Gallery Toi o Tamaki.

${ }^{33}$ Ron Brownson, interview with the author, 6 November 2006.
} 
it is interesting to note that Ross also appears to have asked about McCahon's archival habits, particularly relating to his own work. McCahon's reply is that he keeps almost no records of his paintings. ${ }^{34}$

Interestingly, given the debate about the elder painter's influence on Ross's refusal to exhibit, McCahon comments on the misinterpretation of his portrait Hilary as the Virgin and the Child Jesus as Jews in the Press (after it was exhibited in Christchurch). Here, McCahon provides a concrete example of the pitfalls of placing one's work into the public domain, where efforts to communicate to a wider audience can result in incorrect interpretations of artistic intent.

My overall impression of the relationship between McCahon and Ross gleaned from these archival fragments is that it was clearly more personal in nature than a passing acquaintance or strictly professional interaction, something also suggested by a number of people interviewed over the course of my research. McCahon states in the second of the two letters that he was pleased his earlier correspondence gave Ross ."pleasure and help in a time of need", and this itself suggests a certain degree of intimacy and empathy in their relationship. But it is also important to highlight that while McCahon's letters respond in detail to questions posed by Ross, they ask few in return of him or his situation.

There can be no question that Ross valued highly the work of McCahon, and that he cherished the personal instruction he received from such an important New Zealand painter, but I would argue McCahon's influence on Ross had more to do with nurturing the younger artist's unique creative sensibility than developing his artistic style. This is a view backed up by Douglas Wright, who comments:

I don't think that McCahon had the influence on him as a practitioner or as a philosopher that Duchamp did, but McCahon had an influence because McCahon was a great artist and I think he saw in Malcolm that here was someone who also had their own voice, and they both

\footnotetext{
${ }^{34}$ Colin McCahon to Malcolm Ross, 27 March 1972. Colin McCahon Archive, E.H.
} McCormick Research Library, Auckland Art Gallery Toi o Tamaki. 
recognised each other and so their relationship, however informal, was one of equals really - I think, from the sound of it. ${ }^{35}$

For the most part forgoing any attempt to follow in the stylistic footsteps of McCahon, Ross realised that to forge his own artistic voice he would need to transcend the influence of his teacher. ${ }^{36}$ This may be why, on returning to Elam in 1971 for his honours year, Ross chose to enrol in the sculpture department. According to Wright, Ross claimed that "when [he] changed from painting to sculpture at Elam, McCahon came to his studio and was furious."37 This reaction would seem to rub against Brownson's claim that McCahon most admired those whose approach differed from his own, and yet I think that while this appears to present a contradiction, McCahon's reaction is to some extent human and understandable. For if McCahon did perform the role of an artistic father-figure for Ross at the time, then Ross's decision to change from painting to sculpture might, justifiably, be seen as a rejection of his influence. If McCahon was angry, the anger seems likely to have been confined to his initial reaction, as suggested by the encouraging tone of the aforementioned correspondence which dates from after Ross's switch to the sculpture department. Ross's artistic sensibility, which saw him seek to establish his own creative approach, is highlighted by Paul Hartigan's comments below:

There were a lot of people who were trying to imitate Colin McCahon at art school, it was a fashionable thing. While all those people were doing that it seemed like a dead end to me, a cul-de-sac. I remember one quick conversation Malcolm and I had about McCahon ... he said, "But we had to reject them. They're your teachers, you got to reject them to move on." 38

It seems a good opportunity here to flesh out the above discussion with reference to specific works from Ross's oeuvre which in differing ways invoke McCahon. In particular I wish to focus on two works, namely Untitled [Hollywood McCahon] (undated, Malcolm Ross Archive) [Fig. 14] and Near

\footnotetext{
${ }^{35}$ Douglas Wright, interview with the author 6 November 2006.

${ }^{36}$ Ross's work Near Miss, however (which I will discuss below), is a notable exception, in which Ross consciously reworks McCahon's style and iconography.

${ }^{37}$ Douglas Wright, interview with the author, 6 November 2006.

${ }^{38}$ Paul Hartigan, interview with the author, 7 November 2006.
} 
Miss (1992, p.c.) [Fig. 16], and briefly explore what they might reveal, in tandem, about Ross's artistic connection to McCahon.

Like many of the sketches in Ross's archive, [Hollywood McCahon] is an ink drawing on paper which may well have been a preparatory outline for either a never-created or now-destroyed painting. Like many of these sketches, it might be considered something of a throw-away, and yet I would argue it still has much to say. In this 'work' Ross references the famous Hollywood sign, replacing the name of the Los Angeles suburb with that of McCahon in a double-quotation typical of his practice. ${ }^{39}$ In doing so, Ross seems to be granting an iconic status to his former teacher, associating his name with the glamorous allure of the Hollywood film industry. ${ }^{40}$ But I believe the work also suggests that, just as Mondrian's artistic achievements provided an obstacle for McCahon to overcome in order to develop his own style, McCahon presented a similar impediment for Ross. Writing on Mondrian, McCahon wrote: “. . . it seemed to me, [he] came up in this century as a great barrier the painting to END all painting. As a painter how do you get around either a Michelangelo or a Mondrian?"41

The painting Here I Give Thanks to Mondrian (1961, Auckland Art Gallery Toi o Tamaki) sees McCahon directly acknowledging the artist he both greatly admired and viewed as a 'barrier', and to my mind there seems to be an almost ritualistic or shamanistic aspect to the work - an idea that somehow, if McCahon's debt to Mondrian is made explicit, it will enable him to move past the modern master, to more easily develop and take control of his own artistic style, just as prehistoric cultures believed that the very act of depiction created

\footnotetext{
${ }^{39}$ For example, Duchamp Foundation, which is discussed further in the next chapter, explicitly evokes Duchamp whilst also alluding to Rodin's The Thinker.

${ }^{40} \mathrm{~A}$ connection between McCahon and the film industry is reinforced in another item from Ross's archive, in which a photocopy of a clapper-board is given the title From the Mc Cahon collection.

"Colin McCahon, notes to the Colin McCahon Survey Exhibition, Auckland City Art Gallery (1972). Colin McCahon Archive, E.H. McCormick Research Library, Auckland Art Gallery.
} 
a power over the subject depicted. ${ }^{42}$ t think a similar form of ritual, a similar combination of acknowledging the skills of the master whilst also highlighting the challenge they present to move past them, is in operation in [Hollywood McCahon].

It is interesting to note that [Hollywood McCahon] bears a striking similarity to Ronnie van Hout's Dead Artists (1992, p.c.) [Fig. 15], in which the name of McCahon (along with Angus and Lusk) is also presented as a threedimensional object populating the side of a hill. While I would suggest the two works were conceived and executed entirely independently of one another that there is no direct relation of awareness between - to my mind they seem strikingly similar in both appearance and intent. And although due to the fact that [Hollywood McCahon] is undated it is difficult to prove conclusively, based on my experience with Ross's archive material I believe it is possible that Ross's work predates van Hout's by a decade or more. This comparison may provide an example of Paul Hartigan's observation that:

[Ross's art] seems to pre-empt so much work that's been made in the last 20 years or so by ... people like Ronnie van Hout and Peter Robinson. It just makes other stuff look so flaccid. More finished things, more acceptable things, things that are clearly held up as important New Zealand works, they do seem to have currency until you encounter a lot of what Malcolm did. ${ }^{43}$

Like [Hollywood McCahon], Ross's Near Miss immediately brings to mind his former teacher's work, although in this case this conjuring is achieved via its stylistic and iconographic similarities to McCahon's painting, in particular Crucifixion with Lamp (1947, Hocken Library, Dunedin) [Fig. 17]. Near Miss is intriguing on a number of levels, and provides a relatively rare example of a finished painting which has been signed, titled and dated by Ross. As a sketch of the work is included in Ross's archival material in the Auckland Art Gallery,

\footnotetext{
${ }^{42}$ Commenting on the work McCahon writes: "the words 'Here I give thanks to Mondrian' reflect my admiration for the gentleman. It was only at this stage did I realise his importance as a painter." Colin McCahon with Gordon H. Brown. 'All the paintings, drawings and prints by Colin McCahon in the gallery's collection', Auckland City Art Gallery Quarterly 44, 1969, pp 13-14.

${ }^{43}$ Paul Hartigan, interview with the author, 7 November 2006.
} 


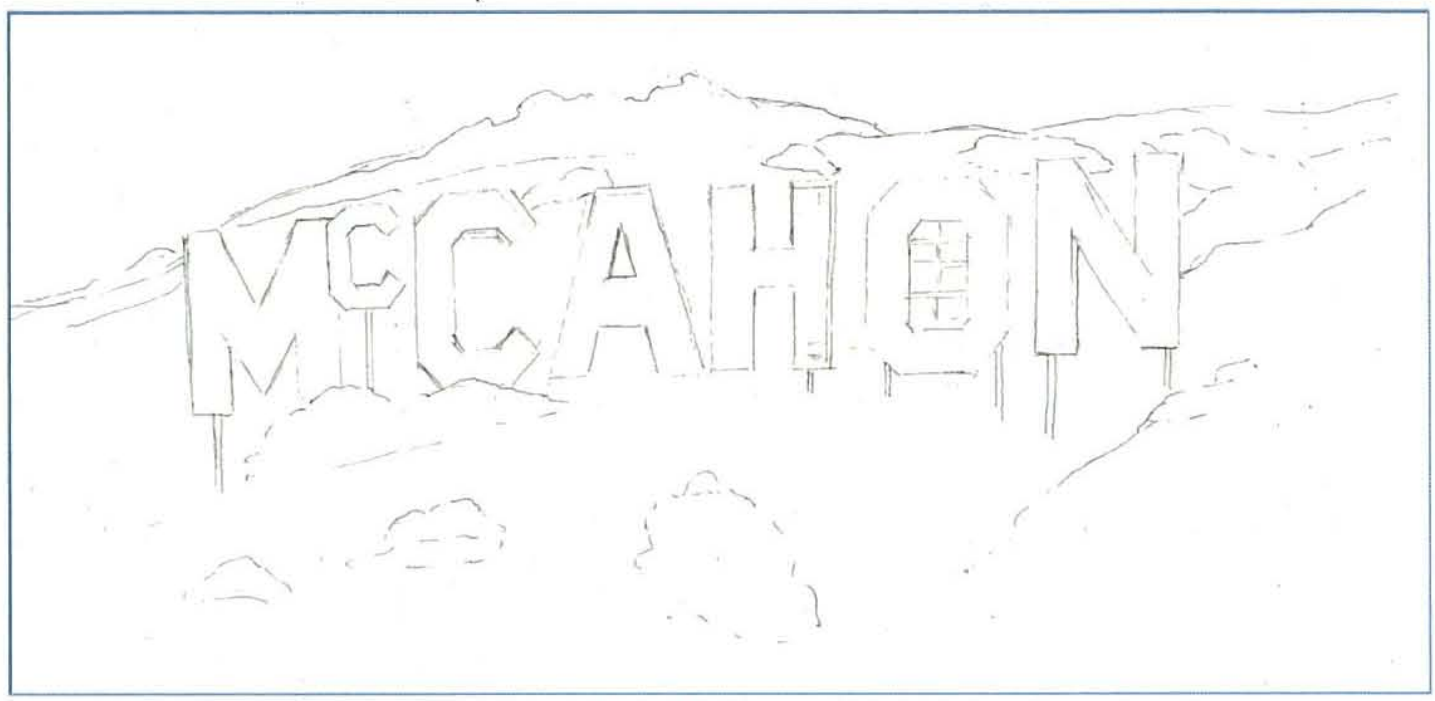

Fig. 14. Malcolm Ross, Untitled [Hollywood McCahon], undated Ink on paper

E.H. McCormick Research Library, Auckland Art Gallery Toi o Tamaki

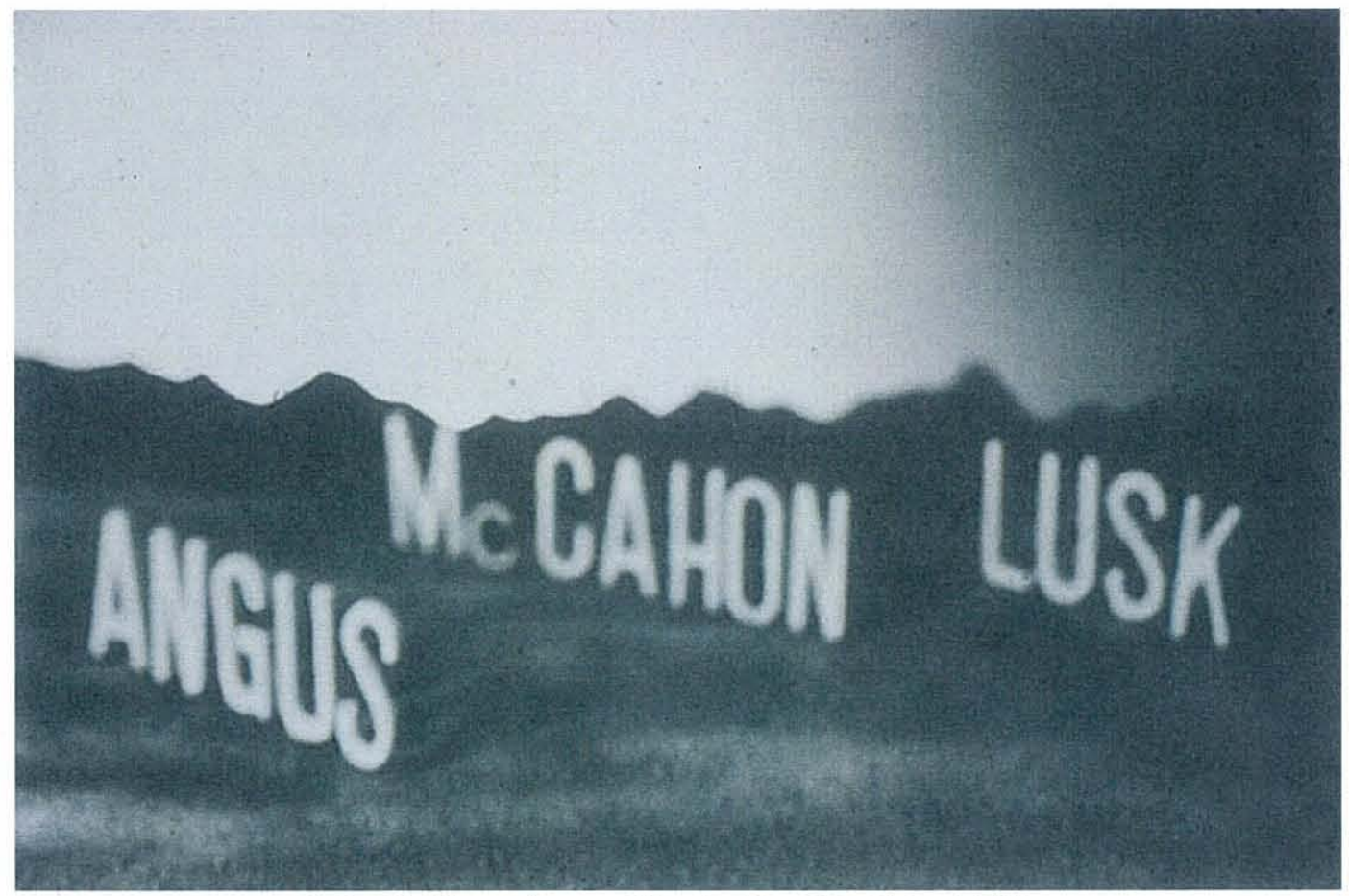

Fig 15. Ronnie van Hout, Dead artists, 1992

Black and white photograph

Private collection, Wellington 


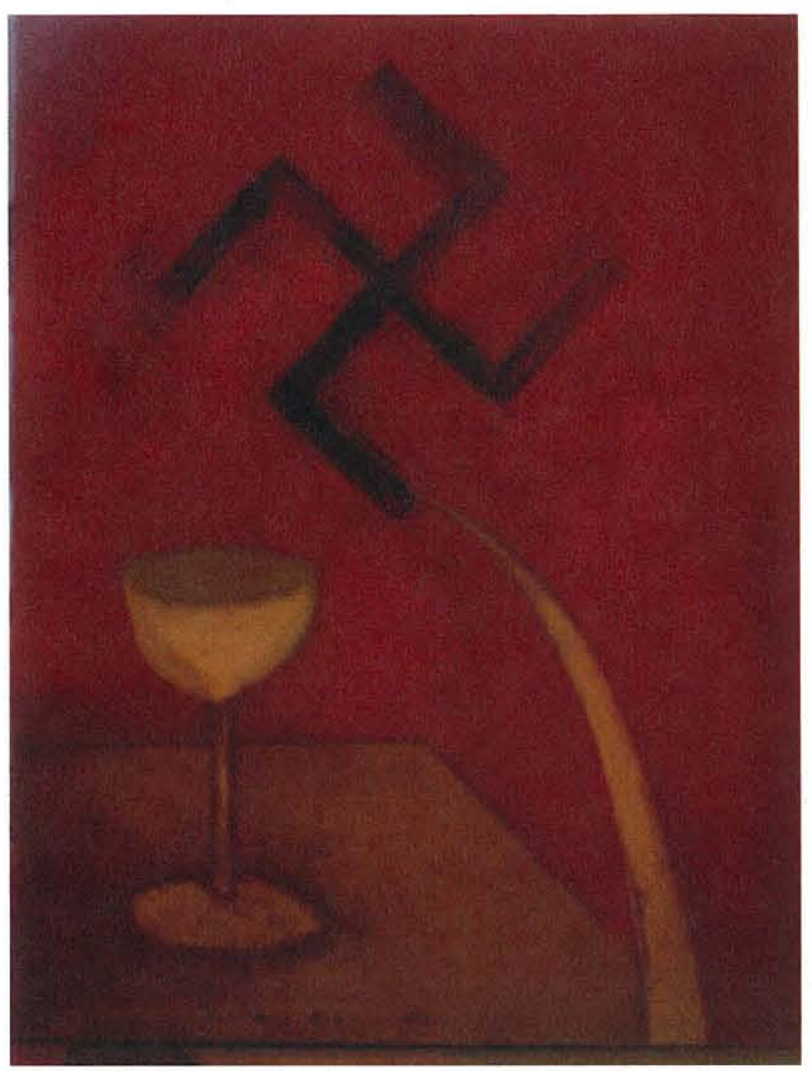

Fig. 16. Malcolm Ross, Near Miss, 1992

$$
\text { Oil on board }
$$

Douglas Wright collection

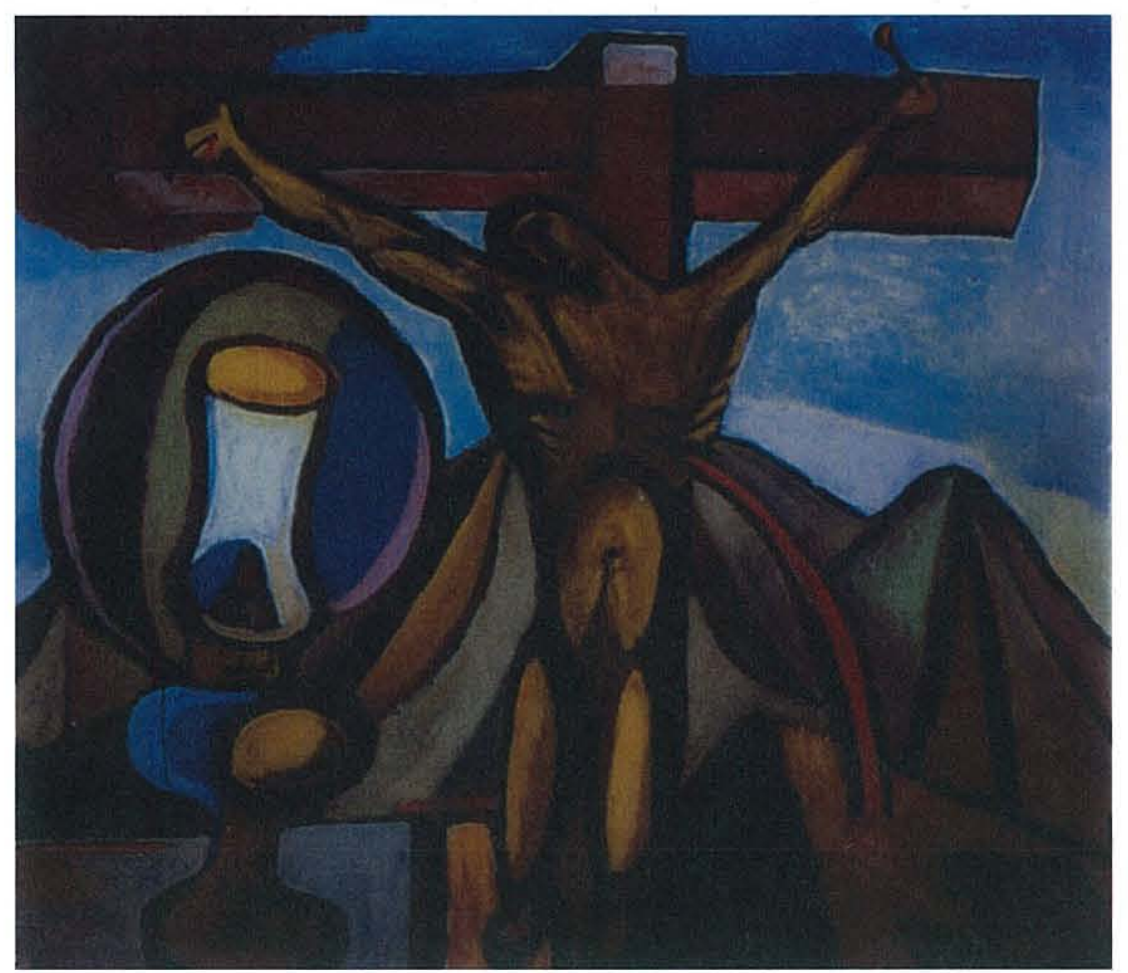

Fig. 17. Colin McCahon, Crucifixion with lamp (detail), 1947

Oil on canvas

Hocken Library, Dunedin 
it also shows the transition from hastily drawn idea to finished work, providing an edifying glimpse into his creative process.

Near Miss also presents a challenge to my previous claim that Ross eschewed aping McCahon's style, although the subversive edge which Ross gives to the image clearly separates it from Crucifixion with Lamp. A direct comparison between the works seems instructive here. McCahon's image presents the viewer with a composition dominated at its centre by the figure of Christ on the cross, positioned against a backdrop of the boldly-outlined hills which surround Nelson. Bright red blood flows from the right of Christ's torso, forming a neat arc that resembles McCahon's latter visual description of waterfalls, and pours into the autochthonous soil of the hill below. To the left of the composition is a table which supports a cup, possibly the holy grail, and hovering above, in a kind of animated bubble, is the titular lamp. The work is an example of McCahon imbuing a distinctly local setting with biblical narratives, of granting the land a mythological dimension, with the aim of communicating something he intuited as being innately profound in his native landscape. ${ }^{44}$ Commenting on the symbolic strata of the work, Gordon $\mathrm{H}$.

Brown writes:

In this context the lamp emits a double meaning as a symbol of God's mysterious wisdom to the faithful, the lamp that illuminates the path in a time of darkness, and as signifying the mission of Christ, the light that shines as an example to all the world. Compositionally the lamp as a visual symbol of Christ shedding his light before mankind is balanced by the symbolic representation of his blood being shed for humanity as it flows from the wound in his side. There is also a significant spatial progression in the painting from the foreground lamp to the crucified Christ, and on to the background hills, all bound rhythmically together by a cross pattern of arching lines. In this way the localized Nelson hills are caught up in the cosmic forces of the divine sacrifice, the arch of the streaming blood being echoed in the hills. $^{45}$

\footnotetext{
${ }^{44} \mathrm{McC}$ ahon describes the experience of driving toward the Taieri Plain and how one day he 'first became aware of my own particular God....there was a landscape of splendour, and order and peace' in 'Beginnings' Landfall 80 (20.4) December 1966, p 364.

${ }^{45}$ Gordon H. Brown, Colin McCahon: Artist, A.H. and A.W. Reed: Wellington, 1984, p 43.
} 
Near Miss copies key iconographic elements from Crucifixion with Lamp but makes several omissions and substitutions which subvert the meaning of McCahon's painting. By removing the lamp, Ross removes the symbolic illumination of "God's mysterious wisdom" that Brown saw in McCahon's work, thus creating a work which is both figuratively and literally darker than its 'model'. By substituting the image of Christ on the cross (perhaps the most well-known symbol of redemptive sacrifice in Western iconography) with the swastika, another ancient religious symbol - but one now inextricably linked to the travesties of Nazi Germany - Ross further darkens the mood. And in contrast to the stoic hills which provide the backdrop for McCahon's painting, Ross opts for a stark background of blood-red. If any religious geography is being invoked here, it seems more likely to be hell than heaven. One implication of these substitutions might be that while McCahon saw infinite potential in the New Zealand landscape, Ross's view, in this work at least, was of something much bleaker.

The title of the work, Near Miss, offers many potential interpretations. Most literally it might refer to that fact that the arc of white that emerges from the swastika has narrowly missed the cup waiting to receive it. This reading offers a kind of banal humour that Ross did not shy away from - it could be viewed as another variant of the "groaner" that he identifies in the introduction to his thesis. Viewed in the context of twentieth-century history, the title might also refer to a close shave with foreign occupation. Ross could be seen to suggest that, had the Second World War ended differently, the untainted, biblical landscape depicted in McCahon's work might have been corrupted forever by the forces of fascism.

I believe a clue to the meaning of the work's title is located in Ross's sole published article, a review of Chris Booth's Nga Tamariki a Tane for Art New Zealand. Although writing about another artist, Ross's attitudes and ideas about art are nonetheless clearly projected in the text. Most relevant to the current discussion is his comment that "worthy causes in art are high-risk. The 
penalty of a near miss is to become twee. If marginally more successful, one can appear merely sanctimonious." ${ }^{\prime 46}$ If there is an intentional connection between his art writing and a subsequent work here, it would be in keeping with Ross's lifelong artistic approach, in which various, disparate strands of his creative output are consciously interwoven via quotation. In these comments Ross highlights the danger of failure in artistic endeavours, and the threat of failure might be seen to hang over his entire artistic project. This fear of failure, this fear of appearing twee or sanctimonious in the eyes of an imagined audience, provides a plausible, if perhaps only partial, explanation for why he chose to refrain from exhibiting his work.

Applied to the painting Near Miss, Ross's comments about "worthy causes in art" can be seen to suggest that here the title intentionally, and selfdeprecatingly, critiques the very work it names. In other words the title implies that the work itself is flawed, a failure, a near miss. But if Ross did view the painting as a failure, it is interesting to point out that he nevertheless 'signed off' on the work, surrendering it to history by affording it the historical conventions of date, title and signature. Once again Ross can be seen to utilise the pun (Near Miss can be a either a lucky escape or an interesting failure) and a combination of the visual and the verbal is used to create a rich, conceptual loop of possibilities difficult to pin.down definitively.

One final interpretation of the title Near Miss brings us back to the question of the extent to which McCahon was influential on Ross's decision to refrain from exhibiting his work. In this (perhaps more tenuous) reading, the work's title might be seen to refer to Ross's fortunate escape from the pitfalls of public reception, something that his mentor McCahon had almost certainly warned him about. Perhaps Ross operates in the style of McCahon here to make this connection explicit. In this work Ross might thus be seen to present an alternative trajectory of his art practice in which his career more closely

\footnotetext{
${ }^{46}$ Malcolm Ross, 'Chris Booth's Nga Tamariki a Tane', Art New Zealand 30, Autumn $1984, \mathrm{p} 14$.
} 
mirrored his mentor's, with the combined implication of title and oppressive imagery being that this would not have been an entirely positive scenario.

As I have alluded to above, in many ways Ross and McCahon were kindred spirits: both were highly creative individualists prone to introspection and depression, both used and abused alcohol in a failed attempt to mitigate their melancholia, and McCahon certainly suffered (particularly early on in his career) from scathing comments about his work from both the public and critics. An infamous example of this negative response is provided by critic A.R.D. Fairburn, who, commenting on a group of works exhibited in the 1947 group show which included McCahon's Crucifixion with Lamp, was rather caustic. Although he begins the review by acknowledging that McCahon is "a man of talent", Fairburn goes on to write: "the home-spun pretentiousness of these drawings distressed me ... in every attribute of good painting they are lacking ... they might pass as graffiti on the walls of some celestial lavatory - but that is about all. Pretentious hocus of this kind is bad for the politics of art. ${ }^{477}$ It could be argued that reviews such as these soured McCahon on the process of exhibiting to such an extent that when he encountered a kindred spirit in Ross, he discouraged him from following the same path in order to be spared the heartache of seeing one's creations attacked by a hostile and unreceptive public who failed to understand the work.

This reading seems similar to Paul Hartigan's interpretation of McCahon's influence on Ross. He states:

I think McCahon was a damaging influence on Malcolm in some ways ... I think he was saying things to Malcolm like: "This whole exhibiting publicly is a mugs' game. If you're a real artist you don't need that shit. You've got to be true to yourself. Public success doesn't matter." That's what I believe McCahon was saying to Malcolm, and I believe that that idea was heavily instilled ... I think that to some degree with Colin McCahon's trajectory and overview on that, for Malcolm to then go and exhibit publicly - he could have lost face. . . my overriding impression of the relationship is that [Ross had] huge admiration for Colin McCahon, McCahon was the great god, and

${ }^{47}$ A.R.D. Fairburn, 'Art in Canterbury', Landfall 5 (2.1), March 1948, pp 49-50. 
yet he imposed all his insecurities, and Malcolm was a repository for them to some degree. ${ }^{48}$

Although Hartigan's impressions would have been informed by his conversations with Ross, they also entail an element of speculation, and are informed, I suspect, by witnessing Ross struggle with his own demons over a number of years. If Ross was a repository for McCahon's insecurities, I would argue it was primarily because they resonated so strongly with his own. Somewhat at odds with Hartigan's views are those of Ron Brownson, who believes that rather than discouraging Ross from exhibiting, McCahon was more likely to have been critical of the exhibition process. ${ }^{49}$ The distinction between these two views is a fine but crucial one: in one instance blame is laid squarely at McCahon's feet, in the other personal responsibility is laid at Ross's.

While it may be impossible to know for certain exactly what [mixed] message McCahon conveyed to Ross on this subject, it is possible to ascertain that Ross, at the very least, claimed McCahon discouraged him from exhibiting. In Ghost Dance, Douglas Wright writes that when he asked Ross why he didn't exhibit his work, Ross "prevaricated. He told me McCahon had warned him against exhibiting but that didn't ring true [to me] as a good enough reason to sacrifice a career." 50

But in view of the fact that Ross had prevaricated in response to Wright's question, and that Wright had felt that this excuse didn't ring true, I am inclined to side with Wright. Ross would have been asked about his refusal to exhibit so often that having an answer at the ready would have been a matter of convenience. But I suggest that whilst McCahon may have warned Ross about the cost of exhibiting publicly, the decision was his alone, shaped by a range of factors including the examples of Duchamp and his mother, Ruth

\footnotetext{
${ }^{48}$ Paul Hartigan, interview with the author, 7 November 2006.

49) Ron Brownson, email to the author, 30 November 2006.

${ }^{50}$ Douglas Wright, Ghost Dance, p 190.
} 
Ross, and also to a large extent his own fear and cowardice. ${ }^{51}$ As Douglas Wright points out:

I think that he suffered all his life from the incredible pain of knowing that he would never know [what it would be like to exhibit his work publicly]. . .But I think that that was a life-long pilot flame burning his skin; that he had made this decision which was absolute, and it was really a renunciation, and it was done out of . . I d don't think cowardice is too strong a word, but well, fear anyway, at least fear and it was a strategy, a gamble and I think that due to the quality of his mind he will prevail, I think that his gamble will pay off actually. ${ }^{52}$

${ }^{51}$ For further discussion of this point see 'I'll still be here when you're gone: the archival strategy of Malcolm Ross', Reading Room 1, 2007, pp 175-180.

52 Douglas Wright, interview with the author, 6 November 2006. 


\section{'DUCHAMP FOUNDA'THON'}

\section{The conceptual underpinnings of Malcolm Ross's practice}

"Duchamp was everywhere in our flat .. . we had a fake letter from Duchamp in our toilet . . Malcolm never really talked about Duchamp, but the evidence - the visual evidence - was that Duchamp was his master."

- Douglas Wright ${ }^{!}$

As suggested by the quote above, Marcel Duchamp's influence on the development of Malcolm Ross's artistic sensibility is difficult to overstate. Time and again, and in numerous ways, Ross's work evokes Duchamp. The French master's influence can be seen in Ross's constant utilisation of visual and verbal puns; in his efforts to leaven works with humour and irony; in his exploration of the potential to infuse art with an erotic sensibility; and, most fundamentally, in his consistent attempt to create art based on ideas. As suggested by the title of this chapter, Ross's conceptual approach is built on a foundation laid by Duchamp. But I will argue Duchamp's example was instructive for Ross not just in terms of art production, but also in the way an artist could obtain freedom by pursuing an approach which contravened convention. He illustrated to Ross that it was possible to have an artistic career whilst operating at one remove from art world, that there was validity in addressing one's works not to the fickle tastes of the public, but to posterity.

In this discussion I will chart the various ways in which Duchamp's example proved instructive for Ross, highlighting many similarities in both their artistic sensibilities and unconventional approach to a life dedicated to art. I will examine items from Ross's oeuvre which can be seen to reference, explore, and expand upon Duchamp's work, and will finally consider the extent to which Duchamp might be seen to influence Ross's decision not to exhibit his work.

\footnotetext{
${ }^{1}$ Douglas Wright, interview with the author, 6 November 2006.
} 
To begin this account I propose to examine the work which provides the title for this section of my thesis. Housed in his archive at the Auckland Art Gallery, Duchamp Foundation (c.1980) [Fig. 18] is a black and white photograph which depicts Ross literalising his title, standing on a bag marked with the titular phrase. Much like McCahon's painting Here I Give Thanks to Mondrian (1961, Auckland Art Gallery Toi o Tamaki), this work explicitly acknowledges the importance of a master practitioner in an apprentice's development, and like Here I Give Thanks to Mondrian, Duchamp Foundation suggests that the influence of such an artistic father-figure is difficult to move beyond. As Mondrian's mastery of modernist painting presented a barrier for McCahon, so too is Duchamp's shadow hard for Ross to escape.

As in [Elam Studio Self-portrait], the pose adopted by Ross in Duchamp Foundation quotes from historical art, in this case approximating Rodin's The Thinker (1902, Musée Rodin, Paris). Here, via this double quotation, Ross seems to be giving a clue to the subsequent researcher - simultaneously emphasising the importance of Duchamp in his project and accommodating the kind of artistic genealogy which is the domain of traditional art history. Indeed, Duchamp Foundation sees Ross accommodating and encouraging a conventional arthistorical narrative, despite challenging this approach elsewhere. ${ }^{2}$ I think it is important to acknowledge that the reference to Rodin's work goes beyond facilitating an artistic genealogy however. If I have argued that Duchamp's influence encouraged Ross to operate in a conceptual manner, to turn his art to the service of the mind, then the quotation of a work which implicitly evokes the process of thinking can only augment this point further.

It is interesting to note that whilst Ross frequently sought to remove art from the proverbial pedestal which might be seen to elevate and separate it from everyday life, in this image he actually creates one. The object Ross is leaning

\footnotetext{
${ }^{2}$ For example it is no coincidence that Ross states in his thesis that the only signed and dated example of his work is titled Fucking Hell. Malcolm Ross, Untitled (or $A++$ ), Graphics, 15(c), unpaginated.
} 


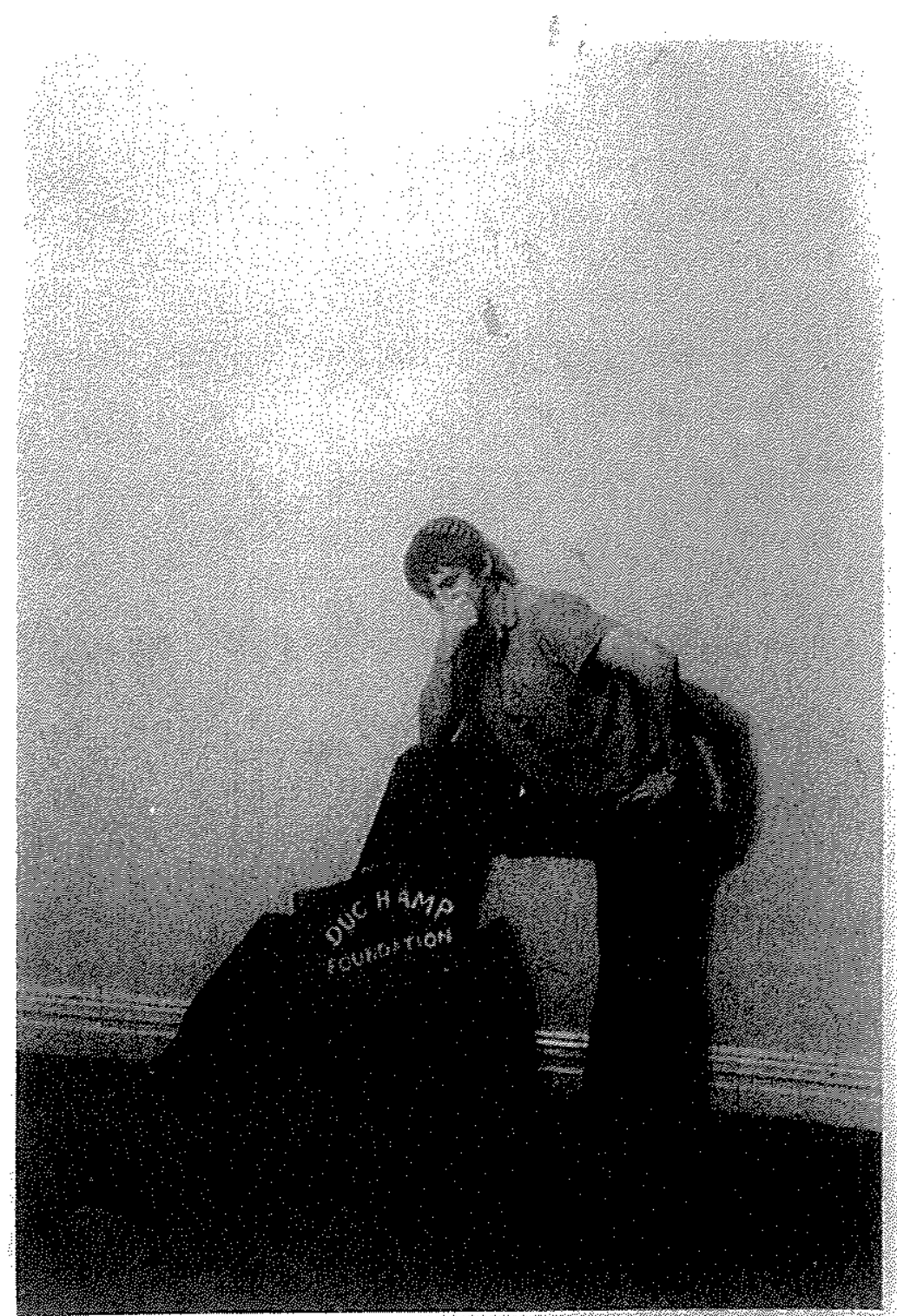

Fig. 18. Malcolm Ross, Duchamp Foundation, c. 1980 Black and white photograph

E.H. McCormick Research Library, Auckland Art Gallery Toi o Tamaki 
on - both literally and metaphorically - here 'Duchamp' effectively becomes the pedestal. It is fruitful to compare this work with another from Ross's archive, which in many ways echoes it. Untitled [High-heeled Pipe] [Fig. 19] is a drawing which intrigues on many levels. It also incorporates the depiction of a pedestal, although the fact that it is presented on a standard A4 page, punch holes inclusive, ensures the work eschews any accusation of preciousness.

Here Ross, in a neat display of draughtsmanship, depicts an image of a shoe resting atop the plinth, but with a heel so high that it extends all the way to the floor, forming the shape of a pipe. ${ }^{3}$ The point of this pedestal is thus revealed - the extra elevation is required to make the visual pun work. But the inclusion of the plinth also has the effect of mirroring the compositional arrangement of Duchamp Foundation. Viewed alongside each other, the similarities between Duchamp Foundation and [High-heeled Pipe] are striking, the aesthetic echo of each work in the other suggesting they operate effectively as a diptych. While I cannot be sure of the extent to which Ross intended these two works to converse with each other in this way, the idea of disparate works of different media being linked together via a gesture of quotation is not uncommon is his work. This approach seems to resonate strongly with Duchamp's claim that "what art is in reality is this missing link, not the links which exist. It is not what you see that is art, art is the gap."4 The way these two works interact may even be seen as a kind of Duchampian erotic interplay between archival companions.

I have argued that Ross's work is most fruitfully viewed in a holistic sense, as a life-long project. This approach is facilitated by the fact that much, although

\footnotetext{
${ }^{3}$ It is interesting to note here that this work showcases Ross's well-developed cross-hatching skills. Mark Baldwin recalls that Ross loved cross-hatching and worked diligently to, but there are only a few examples of it in Ross's archival material; a fact that reinforces Ron Brownson's observation that Ross's oeuvre is characterised by "pockets" of different stylistic interest, which occupied Ross for a time before he moved on to try something else. Mark Baldwin, interview with the author, 14/2/2006.

${ }^{4}$ Marcel Duchamp, quoted in Arturo Schwarz, 'Eros c'est la vie,' in Marcel Duchamp, Harry N. Abrams: New York, 1975, p xxxii.
} 


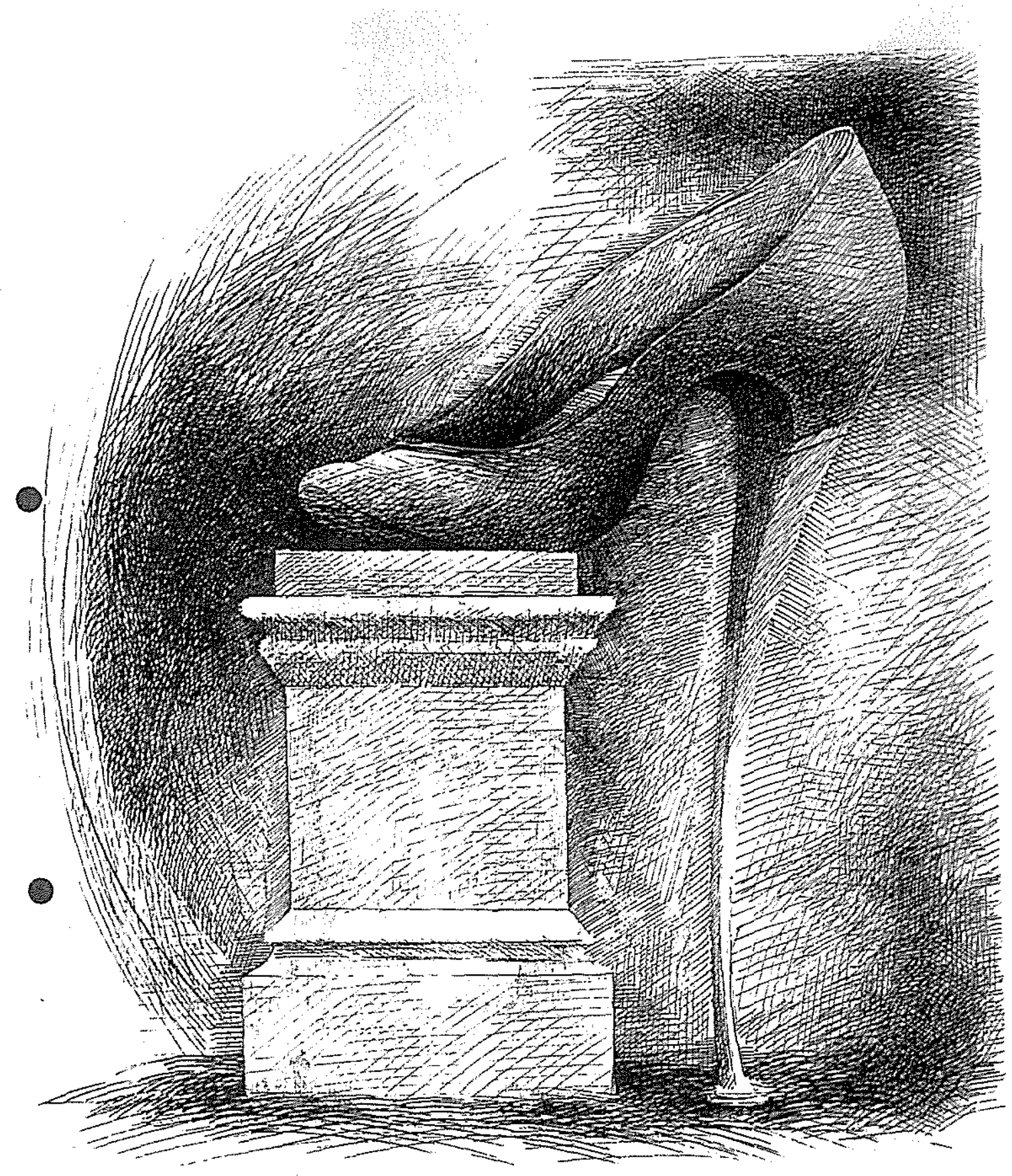

Fig. 19. Malcolm Ross, Untitled [High-heeled pipe], undated Ink on paper

E.H. McCormick Research Library, Auckland Art Gallery Toi o Tamaki 
by no means all, of Ross's extant work is housed in one archival collection. Duchamp similarly desired to have all works assembled in one museum, and his example may once again be seen to influence Ross. But why this point seems salient to this present discussion is that for Duchamp the process of drawing his works together in one space results in a rich and resonant interplay between them. On this point he writes: "I had a certain love for what I was making, and this love was translated in that form." According to Dalia Judovitz, "this inscription of eroticism in the gesture of assemblage suggests Duchamp's particular understanding of his own work as a corpus ... This assembled body of work stages an eroticism that "hinges" on the strategic play of different artistic contexts and media." If this is indeed the case, then I would argue that Ross's body of work also amounts to a corpus, and is capable of operating in a similar fashion.

Although not given a title by Ross, [High-heeled Pipe] is, like Duchamp Foundation, rich with art historical allusions. This drawing can be seen to evoke not only Duchamp, but also the work of Giuseppe Arcimboldo and Rene Magritte. ${ }^{6}$ But whilst Duchamp Foundation is in many ways a relatively 'flat' work which does only a little more than pay homage to Ross's mentor, [High-heeled Pipe] is pregnant with meaning.

If I suggested above that there is an element of eroticism in the interplay between Duchamp Foundation and [High-heeled Pipe], it is important to highlight that the latter work is imbued with an eroticism all of its own. In marrying together the images of the pipe and the high-heel, Ross combines two objects which are conventionally seen to represent masculinity and femininity respectively; the act of rotating the image ninety degrees clockwise can thus be seen to create a hinge between the masculine and the

\footnotetext{
${ }^{5}$ Dalia Judovitz, Unpacking Duchamp: art in transit, University of California Press: Berkeley, Los Angeles, London, 1995, p 226.

${ }^{6}$ The inclusion of a pipe which is not a pipe evokes Magritte's The Treason of Images (1928-29, Los Angeles County Museum of Art), and the image also bears a striking resemblance to a series of his penned illustrations which depict anamorphic objects.
} 
feminine. ${ }^{7}$ It is in this sense that [High-heeled Pipe] brings to mind the work of Giuseppe Arcimboldo. Indeed writing on Arcimboldo's punning images, Dalia Judovitz could easily be describing this work when she writes:

The rotation of the image reveals the fact that meaning is kinetic, since it is mechanically generated through the reversibility of the image. The perceptual unity of the image is fractured by a process of double legibility, suggesting its affinity to linguistic puns. ${ }^{8}$

So far my discussion has centred on two works from Ross's archive which most likely date from the early 1980 s, but his utilisation of the pun can be traced back further, to his honours year at Elam. Indeed, at the very beginning of his thesis Ross writes, "As a rule of thumb, my method is to think of a shape, then embarrass the hell out of it. As visual puns they're real groaners." Much of the work documented in Untitled (or $A^{++}$) can be seen to operate in the tradition of the readymade; it frequently quotes, explores, and expands upon ideas suggested by Duchamp. ${ }^{10}$ What this indicates is that, as Ron Brownson points out:

Malcolm Ross, while he was at Elam School of Art, was as informed about Marcel Duchamp as any student could have been with the resources available ... There's no doubt that for Malcolm, Duchamp was absolutely, in terms of twentiethcentury art, the artist he most admired. It's because of certain things that are in Duchamp's identity as an artist. The notion that everyone can be an artist, that the readymade can be an art object, that a gesture to a readymade can transform a work into an art object, that performance and object hood are inseparable, that the arcane content of an art object doesn't need to be readable or comprehensible in order for its intentionality to be self-sufficient. These issues of intentionality, of content, of theme, of breaking traditional forms of how an art object, or how

\footnotetext{
${ }^{7}$ Of course the notion that Ross provides a work that traverses fluidly between the masculine and the feminine itself hinges on the viewer buying into such gender stereotypes. There is no fundamental reason why the 'pipe' could not belong to a woman, nor is it implausible to suggest that the 'shoe' is designed for a cross-dresser. It seems pertinent to point out here that Duchamp himself did not shy away from donning women's clothing to transform into his female alter ego, Rrose Selavy. Taking into account Ross's homosexuality, [High-heeled Pipe] might be viewed as highly camp and humorous image, in which an object is "embarrassed the hell out of" to bring into view societal assumptions pertaining to gender.

${ }^{8}$ Judovitz, Unpacking Duchamp, p 83.

${ }^{9}$ Malcolm Ross, Untitled (or $A++$ ), unpaginated.

${ }^{10}$ For example in Ross's series of Door works, the basic concept suggested by Duchamp's Door; II Rue Larrey, (1927) is comprehensively investigated and developed. Duchamp's work was based on the simple idea that a single door could be reconfigured to serve two doorways in his small French apartment. Ross takes this basic idea and milks it for all it is worth.
} 
an art experience is demarcated is something that he learned from an understanding of what Duchamp did. ${ }^{11}$

In many ways Untitled (or $A++$ ) provides a thorough document of Ross's attempts to absorb the influence of Duchamp and further investigate the implications of his approach. Indeed references to Duchamp come in the very first works documented in Ross's thesis. For example Pegged-out books [Fig. 20] (the very first work reproduced in his thesis), sees Ross create an image which visually echoes the top inscription of Duchamp's The Bride Stripped Bare by Her Bachelors, Even (1915-23, Philadelphia Museum of Art) [Fig. 21]. In hanging books out to dry, he also evokes Duchamp's notion of a "dry" art. ${ }^{12}$ As indicated by Douglas Wright's quote which began this chapter, the visual evidence identifies Duchamp as Ross's master.

It is also clear that Duchamp's influence on Ross extends beyond the realms of art production. Indeed in many ways it was Duchamp who pointed to and predicted the tactic of delayed reception adopted by Ross in his archival approach, which can be seen to take up a strategy suggested by Duchamp, and pursue it to its logical conclusion. As Brownson suggests:

The private life of Duchamp, the fact that he seemingly retired from being a public artist is also hugely influential on Malcolm. There are so many points of comparison that it is not a chance sequence of parallels, these are all things for which he is an exemplar of a way of thinking about visual art where it inhabits your autobiography, that it reflects your biography and it reflects a way of living daily.

Realising the dangers of catering to fickle pubic taste, Duchamp prioritised the valorisation of history over popularity or commercial success. Despite having regular interaction with members of the New York art scene whilst constructing it, he kept secret the work that occupied his attentions for twenty years of his life, Given: 1. The Waterfall, 2. The Illuminating Gas (19461966, Philadelphia Museum of Art). This attitude is clearly expressed in a letter from Duchamp to Jean Crotti, where he suggests:

\footnotetext{
"Ron Brownson. Interview with the author, 6 November 20006.

12 See Dalia Judovitch, Unpacking Duchamp, pp 129-130

${ }^{13}$ Ron Brownson, interview with the author, 6 November 2006.
} 


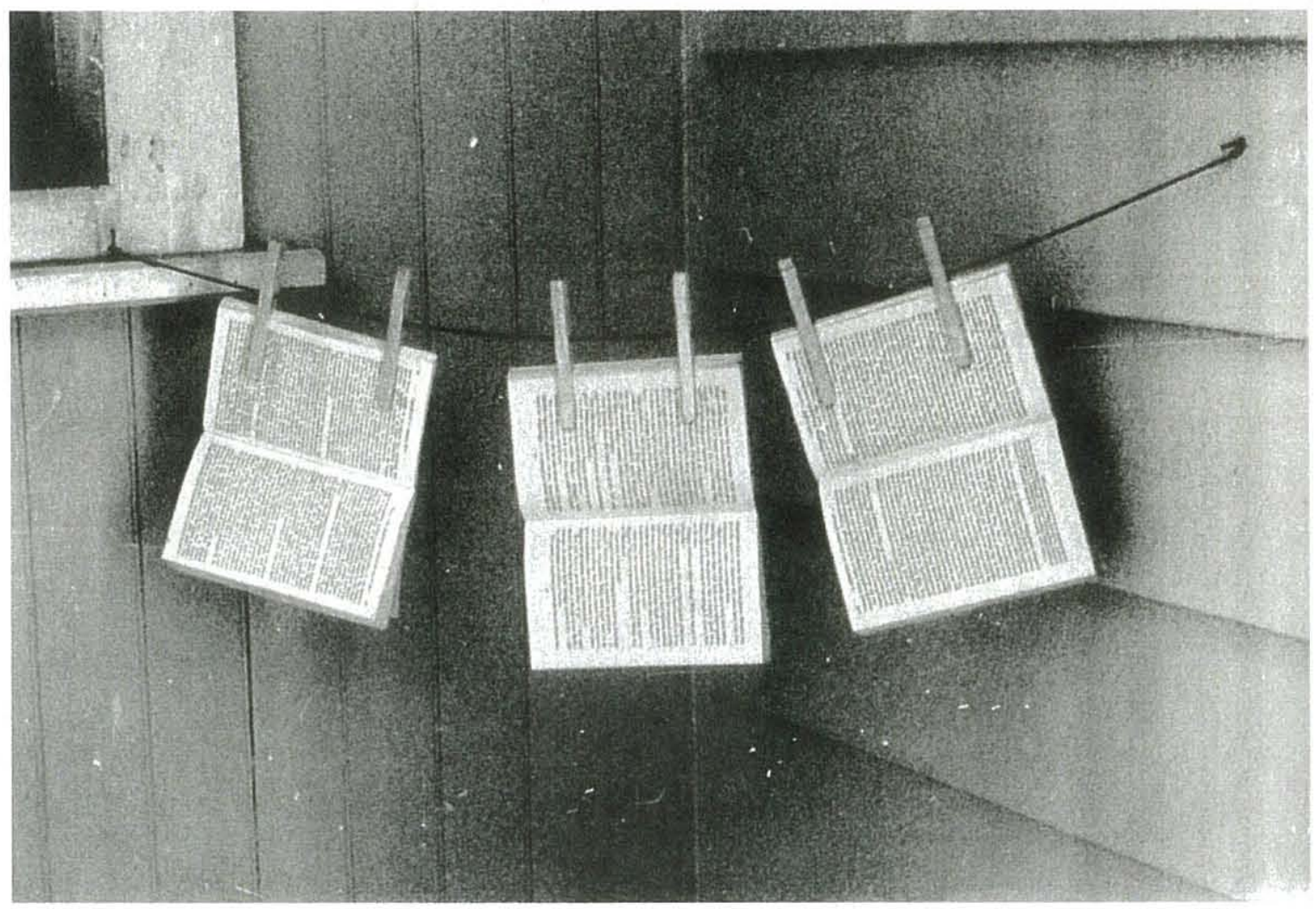

Fig. 20. Malcolm Ross, Pegged-out books, 1971 'Fact', from Untitled (or $A++$ )

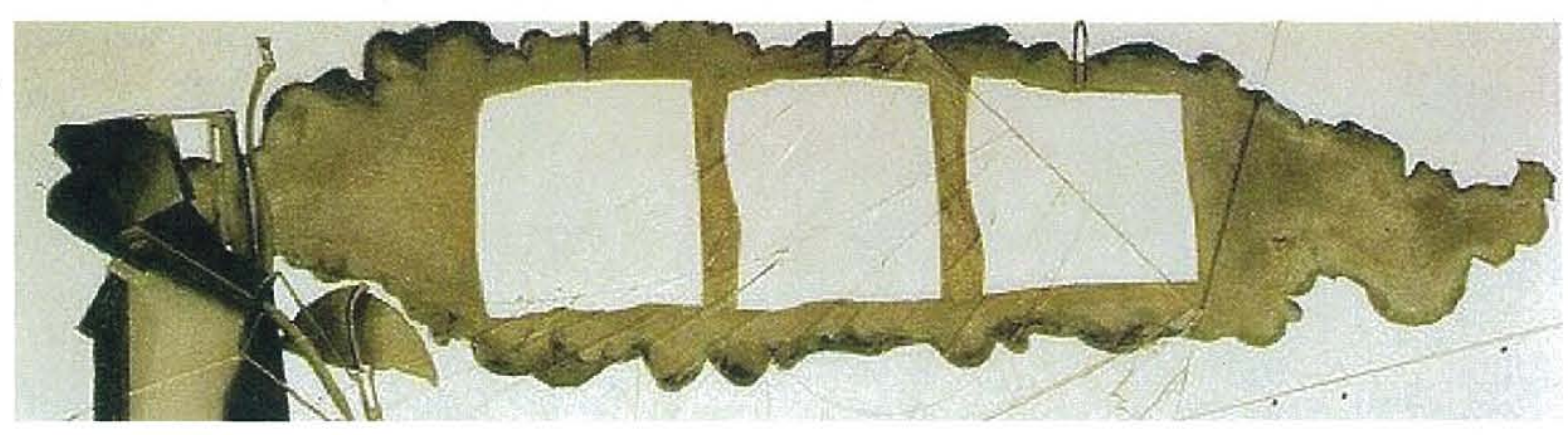

Fig. 21. Marcel Duchamp, The Bride Stripped Bare by Her Bachelors, Even [detail] 1915-23

Oil, varnish, lead foil, lead wire, and dust on two glass panels Philadelphia Museum of Art 
Artists who during their lifetime manage to get their stuff noticed are excellent travelling salesmen, but that does not guarantee a thing as far as the immortality of their work is concerned. ${ }^{14}$

Like Duchamp, Ross never desired to be a travelling salesman of any kind, let alone one flogging his own art.

${ }^{14}$ Marcel Duchamp to Jean Crotti, 17 August 1952, reproduced in Judovitz, Unpacking Duchamp, p 182. 


\section{'I LL STILL BE HERE HHEN YOU RE GONE' \\ Malcolm Ross's archival legacy}

A chronicler who recites events without distinguishing between major and minor ones acts in accordance with the following truth: nothing that has ever happened should be regarded as lost for history.

- Walter Benjamin ${ }^{1}$

So arriving at the end of this account, what can be made of Malcolm Ross and his archival legacy? Before concluding my discussion with a survey of final thoughts from his cohorts, I wish to briefly explore the way in which Ross can be seen to present a specific of image of himself via the archive.

Looking at a collation of self-depictions from the collection, it seems apparent that it is an impression of Ross that is framed in, and by, the archive [Fig. 20]. In absence of a public profile, for Ross the archive becomes an avenue for him to consciously construct an impression of his artistic identity, and present this image to posterity. In conserving only his youthful impressions, Ross refuses to chart the ageing process, to comprehensively document his adult life, and this can be seen to reinforce the notion that the archive serves as a constructive frame where a particular version of the artist is preserved and maintained. Ross has assured that if he is indeed still here after we are gone, his surviving image will be one of youth.

I began this account by suggesting that among his friends Ross was legendary, and it seems appropriate to conclude it with their explanations for why they feel this way. When I asked Paul Hartigan whether he felt there was a place for Malcolm Ross in New Zealand's art history, his response was unequivocal:

Totally. It's amazing to me. I want now, more than ever, to go back and look at his work ... I mean, it's amazing, looking at the work, [how] it seems to pre-empt so much work that's been made in the last 20 years or so. . Malcolm's conceptual work is mind boggling. It just makes other stuff look so flaccid. More finished things, more acceptable things, things that are clearly held up as important New Zealand works, they do seem to have currency until you encounter a lot of what Malcolm did. Perhaps the

\footnotetext{
'Walter Benjamin, 'Theses on the Philosophy of History', in Hannah Arendt (ed) Mlliminations, Schocken Books: New York, p 254.
} 
finish is not as glossy, the page as big, the sculpture as large, but the depth of proposition is huge. ${ }^{2}$

When asked the same question, Ron Brownson replied:

Malcolm Ross could have the position in New Zealand's art history that New Zealand's art history wants to give him. It may give him a reputation that subsists, or even exists, in only two or three paintings that will be regarded as key figure paintings of the period between 1967 and 1977. I believe that he created two or three of the most interesting and challenging figure paintings in New Zealand in that period. Now that's a very small little posthumous reputation - art history might be so generous as to give him just that. Or it could be more inclusive and say ... that Malcolm did something which is more significant than two or three paintings within one decade period . . . but is larger than that, and consists of a whole series of bodies of work that challenge how we feel about history, how we feel about humour, how we feel about sexuality, how we feel about the ability of fantasy to inform the subjects that are available to a visual artist in a manner that is more inclusive, more valuing and perhaps even more cherishing than we have the maturity to allow him to have at the moment. ${ }^{3}$

Finally, Douglas Wright feels that:

even speaking globally, I think that his project is unique. There are very few artists, if any, who have carried their renunciation to that degree, who have got work, or have produced work of that calibre. I would say that he is unique everywhere for that reason. And the work itself would stand up anywhere, the best of his work stands up anywhere. But added to that the fact of his renunciation of any kind of recognition in his lifetime makes it, somehow, morbidly glamorous. You used the word cryogenic ... it's like a time capsule. . . but because he refused to take responsibility for his own life that seriously hampered his growth as an artist. So that's why I think it is true to say that his highpoint is a lot of that early work. ${ }^{4}$

As the above comments suggest, as an art-historical subject, Malcolm Ross is nothing if not interesting. By pursuing a strategy that took to its logical conclusion an approach hinted at by Duchamp, he occupies a unique niche in New Zealand's art history. Ross's claim that he'll still be here after we're gone is true in a sense, for his consciously constructed artistic persona is preserved via the archive. But whether, regardless of his potential "rehabilitation" by posterity, this manoeuvre can only ever amount to a pyrrhic victory remains a moot point. In utilising the tools of history Ross

\footnotetext{
${ }^{2}$ Paul Hartigan, 07 November 2006.

${ }^{3}$ Ron Brownson, 06 November 2006.

${ }^{4}$ Douglas Wright, 06 November 2006.
} 
nullified the efficacy of his self-destructive tendencies and facilitated the potential for art-historical resuscitation.
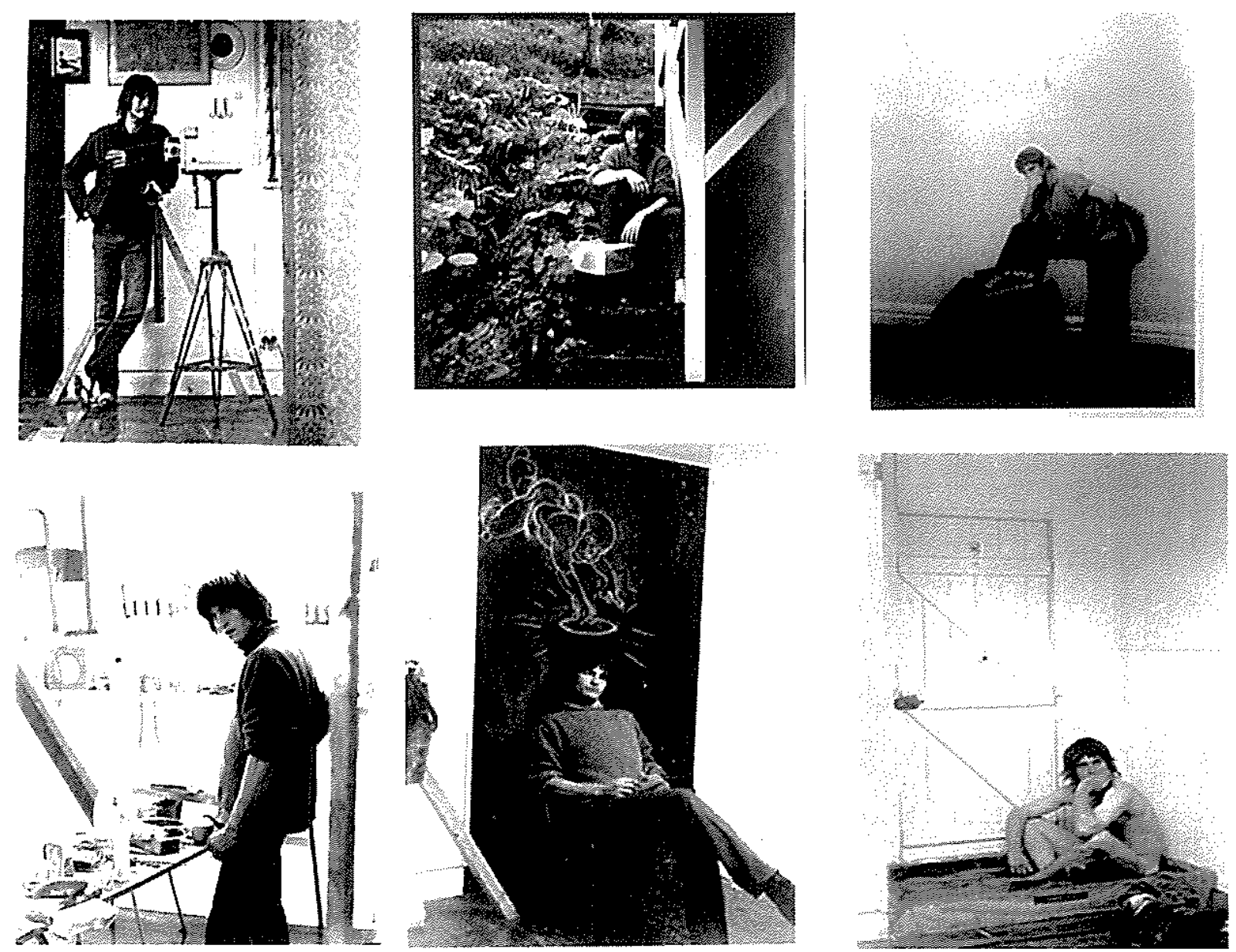

Fig. 22. Malcolm Ross, Selected self-portraits, c1971-1980

Black and white photographs

from Untitled (or $A++$ ) and The Malcolm Ross Archive

E.H. McCormick Research Library, Auckland Art Gallery Toi o Tamaki 


\section{'LONG MAY YOUR REMAINS'}

The Malcolm Ross Archive at the E. H. McCormick Research Library

The following is an amalgam of information pertaining to the archive's inventory compiled by Malcolm Ross, Caroline McBride and myself. The first two boxes, which contain information about The New Zealand Society of Sculptors and Painters, were itemised in detail by Ross himself. Dates in parentheses denote the period the information in each box relates to.

\section{BOX ONE (c.1964-1970)}

\section{NZ Sculptors and Painters A-Z}

Newspaper clippings, photographs, handwritten notes, catalogues, etc, arranged alphabetically, on the following New Zealand artists:

(Names in capitals designate a large quantity of material)

Albrecht, Gretchen

ANGUS, RITA

ASHKEN, TANYA (NZSSP)

Banwell, Ingrid

Batten, Juliet

Bett, Dick

BOOTH, CHRIS

Bowie, James

Braddock, Christopher

Brewer, Logan

Brown, David

Brownson, Ronald

BULLMORE, EDWARD (Ted)

Bustin, Deborah

Cherrie, Derrick

Clarke, Dennis

Clouston, Alison

Conrad, Heinrich
ALLEN, JIM (NZSSP)

Apple, Billy

Ball, Derek

BARBER, BRUCE

Berquist, Ian (NZSSP)

Binney, Don

Borlase, Nancy

Boyd, Ross

Brett, Graeme

Brecknock, Richard

Browne, Mary-Louise

Buis, Linda

Burgess, Rod

Harlton, James

Christensen, Leigh

Clasby, Daniel

Colonna, Peter

CORNISH, BRONWYNNE 
Cullen, Paul

DADSON, PHILIP (From Scratch)

DAWSON, NEIL

Dibble, Paul

Draper, Michael

DRIVER, DON

Dutch, Ted

Elmslie, Gillian

Ffrench, Di

Fomison, Tony

Ford, John Bevan

Furlonger, Stephen

Gascoigne, Rosalie

Gibson-Smith, Peter

Gray, Kim

Hall, Adrian

Hartigan, Paul

Henderson, Louise (NZSSP)

Hotere, Ralph

Hunter, Alexis

Jesson, Robert

Johnson, Rosemary (NZSSP)

Karasek, Laurence

Kingston, John

Lanceley, Cohn

Lee-Gobbitt, Diana

Lett, Barry

Lyons, Kieran

McAuslan, Gordon

McWhannell, Richard

MATCHITT, PARA

Mendelsberg, Martin
Cutcher, Betty

Dawe, Bing

de Boer, Andrew

Draper, John

Drawbridge, John

Drummond, Andrew

Edgar, John

Fergussen, Claire

Field, R.N.

Fountain, Marian

Ford, Malcolm

Garcia-Alvarez

Gibbs, Paul

Graham, Fred

Griffiths, Stuart

Harold, Bryan

HELLYAR, CHRISTINE

Homer, Maree

Howard-Smith, Pamela

Hunter, Ian

Jew, Leo

Karaka, Emily (Emily Pace)

Kindleysides, Edward (Ted)

Killeen, Richard

Lange, Darcy

Lethbridge, John

LYE, LEN

Lynn, Vivian

McCAHON, COLIN

Mansfield, Edgar

Mealing, David

Middleditch, John 
Morison, Julia

Mulvay, Roger

NICHOLLS, PETER (NZSSP)

Olsen, Maria

Pine, Ralph

Parks, Ti

PINE, MATT

Prescott, Alec

Reid, Terry

Roth, Evelyn

Sample, Cathy

SCHOON, THEO

Snowden, Graham

Sullivan, Martin

SZIRMAY, MARTE (NZSSP)

Thompson, Dorothy

Tomkins, Riduan

TURNER, JOHN

Wallace, Lindsay

Watkins, Denys

Wheeler, Jim

White, Maxwell
MUIR, BRONWEN

NARBEY, LEON

Nicholson, Michael

Owens, Hilary

PANTING, JOHN

Peebles, Don

Pwell, Terry

Price, Selwyn

Roche, Peter

Sameshima, Haru

Schamroth, Helen

Shepherd, Stuart

Stringer, Terry

Sydow, Carl

Taylor, Tom

Thomson, Jeff

Tomlin, Jim

TWISS, GREER (NZSSP)

Ward, Robert

Webb, Boyd

White, Jan

Womble, Frank

\section{FILE NOTE}

\section{New Zealand Society of Sculptors and Painters}

Material on the NZ Society of Sculptors and Painters was compiled by Malcolm Ross as part of the research he did as the Society's historian.

Points towards a history of the society include:

- the society was founded in 1961 and incorporated in 1962. Paul Beadle was the first President, Russell Clark vice-President and Jim Allen the first secretary/ treasurer. As well as these, the first council comprised Alison Duff, Cohn McCahon, Kurt von Meier, Peter Middleditch and Greer Twiss. 
- as well as the council members, the inaugural society had 8 artist members and 5 student members.

- in their first published brochure, the society offered professional advice and service to architects, governments, councils, corporations, boards, industrial and commercial undertakings, churches, educational bodies and private individuals

- in a subsequent publication (mid 1970s), the society stated that its aims were to advance the development, understanding and appreciation of Fine Arts in NZ, to encourage the establishment and maintenance of professional standards and practices and to protect the professional interests of its members.

- the society's activities included:

1970: organised a national touring sculpture exhibition 1971: organised the International Sculpture Symposium which brought 5 international sculptors to Auckland to execute works in various locations around the city

- in 1982 the society organised a major survey exhibition of work by its members: Two Decades 1961-1982 which was held at RKS Art.

\section{BOX 2 (c.1900-1991)}

\section{New Zealand and Australian Art and Sculpture}

\section{Folder 1}

New Zealand Society of Sculptors \& Painters

Newspaper clippings, correspondence, catalogues, minutes, handwritten notes, etc. relating to:

- NZ Society of Sculptors, Painters \& Associates exhibition: Two

Decades 1961-1982, at RKS Art

- various pamphlets on the NZSSP

- minutes, annual reports

- information concerning the Smirnoff Sculpture Award

- notes and clippings on the International Sculpture Symposium, 1971 
Folder 2

New Zealand Sculpture - general

Newspaper clippings, correspondence, photocopies, notes, etc. relating to:

- Hansells Sculpture Award

- Fl Sculpture Project, Wellington, 1982

- Mildura Sculpture Triennial

- Stone Sculpture Symposium, Western Springs

- Sculpture exhibitions, events, etc. in New Zealand in the 1960s

\section{$\underline{\text { Folder } 3}$}

\section{Public Sculpture, Monuments, Murals \& Popular Art: 1}

Photographs, postcards, photocopies, newspaper clippings, hand written notes, etc relating to monuments, memorials, public sculpture, murals and other forms of decorative and popular art in New Zealand (excepting Auckland and district), located and documented by Malcolm Ross.

\section{Folder 4}

Public Sculpture, Monuments, Murals, etc: 2

As above, but relating to Auckland and district.

\section{$\underline{\text { Folder } 5}$}

\section{Australian Art and Sculpture}

Newspaper clippings, correspondence, photocopies, hand written notes, etc. relating to:

- general material on Australian art and sculpture, including the South Australian Sculpture Prize, the Contemporary Art Society of Australia, the Sculpture Centre (Sydney), and general clippings on Australian artists

- Society of Sculptors and Associates, Sydney

- Sydney Biennale

$$
\text { ANZART }
$$

Folder 6

NZ Art Organisations and Institutions 
Newspaper clippings, photocopies, catalogues, etc relating to:

- general material on art organisations, including NZ Art Students

Association, Te Aho Artists Society, Auckland Society of Arts, QE II

Arts Council, art awards, etc.

- Pacific Arts Association

- general material on art institutions, including Dowse

Art Museum, Govett-Brewster Art Gallery, dealer

galleries, etc.

- National Art Gallery, Wellington

- Auckland City Art Gallery

\section{$\underline{\text { Folder } 7}$}

\section{Miscellaneous}

Newspaper clippings, photocopies, etc relating to:

- art publications

- art (and other) personalities, critics, etc.

- arts of the Pacific

- art exhibitions, general

- miscellaneous

BOX 3 (1903-1987)

\section{Maori Art}

7 listed folders of clippings, black and white photos, postcards, notes and catalogues.

\section{BOX 4 (cC18th-1989)}

\section{NZ Theatres, Maori Art, Personal}

Ephemera, correspondence, black and white and colour photos, clippings, notes, catalogues, book, photocopied drawings and artwork.

Includes puhoro and Malcolm Ross's artist's file.

\section{BOX 5 (1964-1977)}

\section{Personal}

Black and white negatives, artwork, catalogues, black and white photos 
and other self-depictions from the elam period, ephemera and notebooks. Includes [Elam studio self-portrait] and other self-depictions and negatives of photographs of work documented in Untitled [or $\mathrm{A}++$ ]

\section{BOX 5a (1950-1977)}

\section{Personal}

Three folders: Motukiore sketch book (1950- 1963); Published cartoons (1970s); Looseleaf artworks (pre-1971).

\section{BOX 5b (c1964-c1985)}

Mark Baldwin's artworks (c.1976-c.1985) and Malcolm Ross's artworks (c.1964-c.1976).

\section{BOX 6 (1913-1991)}

\section{NZ Art and Sculpture}

Miscellaneous notes, bibliographic references, catalogues, correspondence, press-clippings, black and white photos. Includes photocopy of Terry Smith's 'The provincialism problem'.

\section{BOX 7 (1930-1993)}

\section{Miscellaneous, NZ Sculpture post-war and pre 1960}

Black and white and colour photos, notes and correspondence from James Ross, Gretchen Albrecht and Alexis Hunter. Also includes a photo of the Elam class of 1975 with the phrase "mirror gives extra dimension" written by Ross on the back, a possible reference to Duchamp.

\section{BOX 8 (1904-1983)}

\section{NZ Sculptors A-H}

Ephemera, and press-clippings.

BOX 9 (1913-1983)

\section{NZ Sculptors I-Z}


Ephemera, notes and press-clippings.

BOX 10 (1948-1991)

NZ Sculptors A-Z

Black and white photos, to be sorted and filed correspondence, ephemera and press-clippings.

BOX 11 (1865-1986)

NZ Sculpture exhibitions and public collections

Ephemera and press-clippings.

BOX 12(1900-1980s)

Foreign statues

Black and white negatives and postcards. A stamp work of Ross's Postcards Foreign Parts may refer to this collection.

BOX 13 (c1900-1984)

Public sculpture in NZ

Black and white photos, notes, correspondence, press-clippings and Postcards.

BOX 14 (c1900-1991)

Public sculpture in NZ

Black and white photos, photocopied notes, correspondence, press-clippings and postcards.

\section{BOX 15 (1869-1989)}

\section{Public sculpture in NZ}

Maps, notes, press-clippings, postcards, black and white and colour photos, cards and correspondence.

BOX 16 (1961-1983) 
New Zealand Society of Sculptors, Painters and Associates (NZSSPA)

\& Miscellaneous

Includes:

- draft report on NZSSPA history, notes and minutes

- book Selected Designs Marble and Granite Memorials (undated)

- bibliographic index cards related to NZ art (undated)

- 2 film strips on NZ post-War sculpture (undated)

\section{BOX 17 (1984-1986)}

\section{NZ Puppet Theatre}

Book, correspondence, press-clippings, black and white photos, meeting minutes and agendas.

\section{BOX 18 (undated)}

\section{Various}

6 black and white photos on card. 


\section{BOOKS APD ARTICLES}

Alberro, Alexander and Stimson, Blake (eds.). Conceptual Art: A Critical Anthology. MIT Press: London and Cambridge, 1999. and Buchmann, Sabeth (eds.). Art After Conceptual Art. MIT Press: Cambridge and London, 2006.

Allen, Jim and Wystan Curnow (eds.). New Art: Some Recent New Zealand Sculpture and Post-Object Art. Heinemann: Auckland, 1976.

Alpers, Svetlana. 'Interpretation Without Representation, or, the Viewing of Las Meninas' (orig. 1983) in Eric Fernie (ed.) Art History and Its Methods. Phaidon: London, 1995, pp 285-290.

Bal, Mieke. Quoting Caravaggio: Contemporary Art, Preposterous History. University of Chicago Press: Chicago and London, 1999.

Louise Bourgeois' Spider: The Architecture of Art-Writing. University of Chicago Press: Chicago and London, 2001.

A Mieke Bal Reader. University of Chicago Press: Chicago and London, 2006.

Barthes, Roland. Image-Music-Text (trans. Stephen Heath). Fontana/Collins: London, 1977. 
'The Wisdom of Art' (trans. Annette Lavers) in Norman

Bryson (ed.) Calligram: Essays in New Art History From France.

Cambridge University Press: Cambridge, 1988, pp 166-180.

Barton, Christina. 'The Last Small World: Jim Allen's New Zealand Environment no 5' in Midwest 1, 1992, pp 29-31.

. 'Pushing the Envelope: Developments at the Govett-

Brewster Art Gallery' in Art New Zealand 87, Winter 1998, pp 56-59.

Traces and Boundaries: The Photographic Legacy of

Post-Object Art. Unpublished, based on a paper presented at "Symposium 2000: An International Conference on Post Object Art in New Zealand", Christchurch, November 2000.

. "What Was Directly Lived Has Moved Away Into a

Representation": Photography and Post-Object Art', in Action Replay Post-Script. Artspace and Govett-Brewster Art Gallery: Auckland and New Plymouth, 2002, pp 14-31.

Bell, Leonard. In Transit: Questions of Home \& Belonging in New Zealand Art (Gordon H. Brown Lecture 2005). Victoria University of Wellington: Wellington, 2007.

Bell, Rachel. Ruth Ross: New Zealand Scholar/Treaty Scholar. Unpublished Master of Arts Thesis, Palmerston North: Massey University, 2005.

Benjamin, Walter. One Way Street and Other Writings (trans. Edmund Jephcott and Kingsley Shorter). Verso: London and New York, 1997. 
Walter Benjamin: Selected Writings Volume 4, 1938

1940 (trans. Edmund Jephcott). Belknap Press: Cambridge and London, 2003.

Illuminations (ed. Hannah Arendt; trans. Harry Zohn).

Pimlico: London, 1999.

Bloem, Marja and Browne, Martin. Colin McCahon: A Question of Faith. Craig Potton/Stedelijk Museum: Nelson and Amsterdam, 2002.

Brown, Gordon H. 'Artists as Photographers' in Art New Zealand 16, $1980, \mathrm{p} 23$.

Colin McCahon: Artist. A. H. and A. W. Reed:

Wellington, 1984.

Brunton, Alan. Years Ago Today: Language and Performance, 1969. Bumper Books: Wellington, 1997.

Cabanne, Pierre. Dialogues with Marcel Duchamp (trans. Ron Padgett). Thames and Hudson: London, 1971.

Calder, Alex. 'F. E. Maning and the European Construction of Tapu', in The Turnbull Library Record 26.1/2, 1993, pp 77-89.

Coulter, Jeff. Rethinking Cognitive Theory. MacMillan: London, 1983.

Curnow, Wystan. 'Writing and the Post Object', in Action Replay PostScript. Artspace and Govett-Brewster Art Gallery: Auckland and New Plymouth, 2002, pp 32-60. 
Derrida, Jacques. Archive Fever: A Freudian Impression (trans. Eric Prenowitz). University of Chicago Press: Chicago and London, 1998.

Writing and Difference (trans. Alan Bass). Routledge: London and New York, 2001.

Duchamp, Marcel. The Writings of Marcel Duchamp (ed. Michel Sanouillet and Elmer Peterson). Da Capo, originally published by Oxford University Press: Oxford, 1973.

Dunn, Michael. 'Present Performance: Sculpture and Painting' in Islands 6 12.4, Summer 1973, pp 369-380.

- 'Paul Beadle' in Nicholas Tarling (ed.) Auckland Minds and Matters. University of Auckland Press: Auckland, 2003, pp 20-31.

de Duve, Thierry. Kant after Duchamp. MIT Press: Cambridge, 1996.

Edmond, Martin. Chemical Evolution: Drugs and Art Production, 19701980. Bumper Books: Wellington, 1997.

. The Resurrection of Philip Clairmont. Auckland University Press: Auckland, 1999.

Faerna, José María (ed.) Great Modern Masters: Duchamp (trans. Alberto Curotto). Cameo/Abrams: New York, 1996.

Fairburn, A. R. D. 'Art in Canterbury' in Landfall 5 (2.1), March 1948, pp 49-50.

Foster, Hal. The Return of the Real: The Avant-Garde at the End of the Century. MIT Press: Cambridge and London, 1996. 
Design and Crime (and Other Diatribes). Verso: London and New York, 2002.

Foucault, Michel. The Order of Things. Vintage Books: New York, 1970.

. This Is Not a Pipe. (trans. and ed. James Harkness). University of California Press: Berkeley, 1982.

. The History of Sexuality: Volume 1-An Introduction (trans. Robert Hurley). Vintage Books: New York, 1990.

Aesthetics, Method, and Epistemology: Essential Works of Foucault 1954-1984, Volume 2 (ed. James D. Faubion). Penguin Books: London, 2000.

French, Blair. Critical Forms: Jim Allen and the Wake of Conceptualism. Unpublished, based on a paper presented at "Symposium 2000: An International Conference on Post Object Art in New Zealand", Christchurch, 12 November 2000.

Ginzburg, Carlo and Herbert, James D. et al. 'Inter/disciplinarity' in The Art Bulletin 77.4, Dec 1995, pp 534-552.

Green, Anthony. 'Culture's Most Remote Province?' in New Zealand Listener Sept 21, 1970, p 22.

Gutting, Gary (ed.). The Cambridge Companion to Foucault. Cambridge University Press: Cambridge, 1994. 
Hall, Adrian [in conversation with Wystan Curnow and Robert Leonard]. 'Bricks in Aspic', Art New Zealand 90, Autumn 1999, pp 34-39.

Hamilton, Carolyn and Harris, Verne et al (eds.). Refiguring the Archive. Kluwer Academic Publishers: Dordrecht, 2002.

d'Harnacourt, Anne and Kynaston McShine (eds.). Marcel Duchamp. Museum of Modern Art and Philadelphia Museum of Art: New York, 1973.

Harold, D. Maori Prisoners of War in Dunedin 1869-1872: Deaths and Burials and Survivors. Hexagon: Dunedin, 2000.

Hughes, Christopher G. 'Embarras and Disconvenance in Poussin's Rebecca and Eliezer at the Well', in Art History, 24.4, September 2001, pp 493-519.

Judovitz, Dalia. Unpacking Duchamp: Art in Transit. University of California Press: Berkeley, Los Angeles and London, 1998.

Kaprow, Allan. 'The Education of the Un-Artist, Part I' in Jeff Kelley (ed.) Essays on the Blurring of Art and Life. University of California Press: Berkeley, 1993, pp 97-109.

Kosuth, Joseph. 'Necrophilia Mon Amour', in Richard Hertz (ed.) Theories of Contemporary Art. Prentice Hall: Englewood Cliffs, 1985, pp 93-101.

Kuspit, Donald. The End of Art. Cambridge University Press: Cambridge, 2004.

Maning, F. E. Old New Zealand. Wilson \& Horton: Auckland, 1863.

McCahon, Colin. 'Beginnings' in Landfall 80 (20.4), December 1966, pp 360-364. 
with Gordon H. Brown. 'All the paintings, drawings and prints by Colin McCahon in the gallery's collection' in Auckland City Art Gallery Quarterly 44, 1969, pp 13-14.

Mclvor, Lois R. Memoir of the Sixties. Remuera Gallery: Auckland, 2008.

McKay, Frank. The Life of James K. Baxter. Oxford University Press: Auckland, 2002.

Merewether, Charles (ed.). The Archive. Whitechapel/MIT Press: London and Cambridge, 2006.

Merleau-Ponty, Maurice. Phenomenology of Perception (trans. Colin Smith). Routledge: London and New York, 2002.

Meyer, Richard. Outlaw Representation: Censorship and Homosexuality in Twentieth Century American Art. Oxford University Press: Oxford and New York, 2002.

Mink, Janis. Marcel Duchamp, 1887-1968: Art as Anti-Art. Taschen: Köln, 2000.

Newman, Michael and Bird, Jon (eds.). Rewriting Conceptual Art. Reaktion Books: London, 1999.

Osborne, Peter. 'Art Beyond Aesthetics: Philosophical Criticism, Art History and Contemporary Art' in Art History 27.4, 2004, pp 651-670.

Paz, Octavio. Marcel Duchamp: Appearance Stripped Bare (trans. Rachel Phillips and Donald Gardner). Arcade: New York, 1990. 
Peters, Roger. William Shakespeare's Sonnet Philosophy, Volumes 1-4. Quaternary Imprint: Kaponga, 2005.

Pitts, Priscilla. Contemporary New Zealand Sculpture: Themes and Issues. David Bateman: Auckland, 1998.

Plummer, Matt. 'I'll Still Be Here When You're Gone: The Archival Strategy of Malcolm Ross' in Reading Room 1, 2007, pp 175-179.

Preziosi, Donald (ed.). The Art of Art History: A Critical Anthology. Oxford University Press: Oxford and New York, 1998.

Quilter, Jenni. 'Forms of Displacement', Landfall 209, May 2005, pp 189-192.

Roberts, John. 'Photography, Iconophobia and the Ruins of Conceptual Art', in John Roberts (ed.) The Impossible Document: Photography and Conceptual Art in Britain 1966-1976. Camerawork: London, 1997, pp 745.

Rogoff, Irit. 'Studying Visual Culture' in Nicholas Mirzoeff (ed.) The Visual Culture Reader. Routledge: London and New York, 1998, pp 1426.

Ross, Malcolm. Untitled (or $A++$ ). Unpublished Diploma of Fine Arts Thesis, Auckland: University of Auckland, 1971.

. 'Chris Booth's Nga Tamariki a Tane', Art New Zealand 30, 1984, pp 14-15. 
Ross, R. M. A Guide to Pompallier House. A. R. Shearer: Wellington, 1970.

Schwarz, Arturo. The Complete Works of Marcel Duchamp. Thames and Hudson: London, 1997.

Smith, Terry. 'The Provincialism Problem' in ArtForum, September 1974, pp 54-59.

Staten, Henry. Wittgenstein and Derrida. Blackwell: Oxford, 1985.

Stead, C. K. 'Towards Jerusalem: The Later Poetry of James K. Baxter' in Islands 32.1, 1973, pp 7-18.

Thomas, Nicholas and Diane Losche (eds.). Double Vision: Art Histories and Colonial Histories in the Pacific. Cambridge University Press: Cambridge and New York, 1999.

Torczyner, Harry. Magritte: Ideas and Images (trans. Richard Miller). $\mathrm{H}$. N. Abrams: New York, 1977.

Wall, Jeff. "Marks of Indifference": Aspects of Photography in, or as, Conceptual Art', in Ann Goldstein \& Anne Rorimer (eds), Reconsidering the Object of Art: 1965-1975. Museum of Contemporary Art and MIT Press: Los Angeles and Cambridge, 1995, pp 246-267.

Wells, Peter. 'A Singular Bliss,' in The Bulletin Winter, June-August 2009, pp 28-29.

Wolin, Richard. Walter Benjamin: An Aesthetic of Redemption. Columbia University Press: New York, 1982. 
Wood, Agnes. Colin McCahon: The Man and The Teacher. David Ling: Auckland, 1997.

Wright, Douglas. 'Beginnings,' Landfall 202, November 2001, pp 8-15. . Ghost Dance. Penguin Books: Auckland, 2004. Terra Incognito. Penguin Books: Auckland, 2006.

Various Authors. 'Questionnaire on Visual Culture' in October 77, Summer 1996, pp 25-70.

\section{EXIIBITOP CATALOQUES}

Cormack, Emily. Archiving Fever. Adam Art Gallery: Wellington, 2006.

Mariani, Philomena (ed.). Global Conceptualism: Points of Origin, 1950s-1980s. Queens Museum of Art: New York, 1999.

Chris Booth: Nga Tamariki a Tane. Auckland City Art Gallery: Auckland, 1983-4.

Colin McCahon: Gates and Journeys. Auckland City Art Gallery: Auckland, 1988.

Marcel Duchamp: The Mary Sisler Collection, 78 Works 1904-1963. City of Auckland Art Gallery: Auckland, 1967.

Militant Artists ReUnion: Tony Fomison, Philip Clairmont, Allen Maddox. Hawke's Bay Cultural Trust: Hastings, 2004. 


\section{ALMS}

Drot, Jean-Jarie (dir.). A Game of Chess with Marcel Duchamp. Phaidon, 1987.

Keddell, William (dir.). Maintenance of Silence. Indeed Film Productions, 1985.

Pooley, Leanne (dir.). Haunting Douglas (including Malcolm Ross interview outtakes). Spacific Films, 2003.

Limbs Dance Company 1977-1989: Excerpts from the Limbs Archive. Arts Council of New Zealand, 1995.

\section{MPTERVEEWS}

$\begin{array}{lll}\text { Jim Allen and Tony Green } & \text { person } & \text { 08 February 2006 } \\ \text { Mark Baldwin and Roger Blackley } & \text { person } & \text { 14 February 2006 } \\ \text { Roger Peters } & \text { email } & \text { 03 March 2006 } \\ \text { Roger Peters } & \text { email } & \text { 16 March 2006 } \\ \text { Roger Peters } & \text { person } & \text { 06 June 2006 } \\ \text { Richard Wolfe } & \text { person } & \text { 14 June 2006 } \\ \text { Mark Baldwin } & \text { email } & \text { 31 August 2006 } \\ \text { Mark Baldwin } & \text { email } & \text { 11 August 2006 } \\ \text { Douglas Wright } & \text { person } & \text { 06 November 2006 } \\ \text { Ron Brownson } & \text { person } & \text { 06 November 2006 } \\ \text { Glenn White } & \text { person } & \text { 06 November 2006 } \\ \text { Paul Hartigan } & \text { person } & \text { 07 November 2006 } \\ \text { Vicky Hamill } & \text { email } & \text { 23 January 2007 } \\ \text { Vicky Hamill } & \text { email } & \text { 08 July 2007 } \\ \text { Mark Baldwin } & \text { email } & \text { 16 September 2007 } \\ \text { Alexis Hunter } & \text { email } & \text { 30 January 2008 } \\ \text { Bronwen Muir } & \text { person } & \text { 04 February 2008 }\end{array}$

